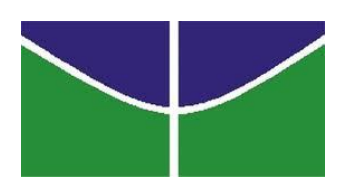

UNIVERSIDADE DE BRASÍLIA - UnB

INSTITUTO DE PSICOLOGIA - IP

PROGRAMA DE PÓS-GRADUAÇÃO EM PSICOLOGIA CLÍNICA E CULTURA - PCL

DO ESTUPRO ÀS FLORES: GÊNERO E ROTEIROS SEXUAIS NA SITUAÇÃO DE VIOLÊNCIA CONJUGAL

RAFAEL GABRIEL ASSIS

Brasília - DF

2015 


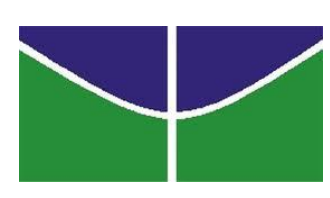

UNIVERSIDADE DE BRASÍLIA - UnB

INSTITUTO DE PSICOLOGIA - IP

PROGRAMA DE PÓS-GRADUAÇÃO EM PSICOLOGIA CLÍNICA

E CULTURA - PCL

\title{
DO ESTUPRO ÀS FLORES: GÊNERO E ROTEIROS SEXUAIS NA SITUAÇÃO DE VIOLÊNCIA CONJUGAL
}

\author{
RAFAEL GABRIEL ASSIS
}

Dissertação de Mestrado apresentada ao Programa de Pós-Graduação em Psicologia Clínica e Cultura (PPGPsiCC) do Instituto de Psicologia (IP) da Universidade de Brasília (UnB) como requisito parcial para a obtenção do título de Mestre em Psicologia Clínica e Cultura.

Orientadora: Prof ${ }^{a}$. Gláucia Ribeiro Starling Diniz, Ph.D.

Brasília - DF

2015 
Dissertação de mestrado apresentada ao Programa de Pós-Graduação em Psicologia Clínica e Cultura do Instituto de Psicologia da Universidade de Brasília, sob a orientação da Prof ${ }^{a}$. Gláucia Ribeiro Starling Diniz, Ph.D.

Banca Examinadora

Profa. Gláucia Ribeiro Starling Diniz, Ph.D. - Presidente

Universidade de Brasília

Profa. Dra. Ana Maria Fonseca Zampieri - Membro Externo

Pontifícia Universidade Católica de Goiás

Profa. Dra. Isabela Machado da Silva - Membro Interno

Universidade de Brasília

Profa. Dra. Júlia Sursis Nobre Ferro Bucher-Malushcke - Membro Suplente

Universidade de Brasília

Brasília, DF 
Às pessoas que são tratadas como menos humanos por estigmas que carregam relacionados ao status que não conseguem ou não querem mudar: etnia, gênero, classe, idade ou qualquer outro tipo de diferença que compareça como desigualdade nas relações sociais. 


\section{AGRADECIMENTOS}

À minha esposa, por tudo. As mais variadas dimensões da conjugalidade em que ela se apresenta como uma companheira incrível dificilmente seriam nomeadas. Agradeço especialmente pela ajuda nas conversações e paciência ao lidar com as inúmeras loucuras cotidianas do autocentramento que compareceu com a realização desse trabalho. A generosidade e gentileza infinitas nunca serão esquecidas.

Aos meus pais e seus cônjuges. A relação entre pais e filhos, por vezes, naturaliza a generosidade dos pais como obrigação de cuidado com os filhos. Vocês foram extremamente generosos, muito além de possíveis obrigações. Aos meus irmãos, sempre grandes amigos me apoiando de várias formas. Aos familiares - sobrinhos, cunhadas, avós (em lembrança), tios, primos - por me oferecerem bastante carinho e atenção e me apoiarem em toda a caminhada. Aos novos familiares, meus sogros, cunhada, vó, primos, tios e outros familiares da Laís, os quais me ofereceram mais do que eu poderia pedir, com amizade e carinho, me estimulando sempre nas minhas buscas profissionais e acadêmicas.

Aos amigos-irmãos Álvaro Amorim, Ana Rosa Amor, André Luiz, Andréa Marques, Bruno Lagares, Carolina Braga, Cláudio Moraes, Creomar Lima, Herivelto Souza, Isadora Brasil, Jaqueline Coêlho, Júlio Alves, Mayarê Baldini, Naiça Bowen, Raquel Guimarães, Rodrigo Suassuna, Stênio Rodrigues, por seu carinho e conversas importantes para o enriquecimento dos horizontes.

À Gláucia Diniz pela orientação e sensibilidade. Apesar de pontos de vista extremamente qualificados, deu abertura para as minhas ingenuidades, me oferecendo perspectivas. A partir da apresentação de perguntas possivelmente irrespondíveis, me indicou caminhos esclarecedores. Pelo olhar atento e estimulante, obrigado!

Aos membros da banca, por suas preciosas contribuições para a produção de conhecimento e para a atuação frente ao sofrimento. Obrigado por aceitarem fazer parte desta etapa da minha vida!

A todos os meus professores, pela paciência e dedicação. No contexto de produção de conhecimento, agradeço especialmente Orlene Lucia de Sabóia Carvalho, por me introduzir à pesquisa e acreditar nos meus potenciais; Ileno Izídio da Costa, por me ensinar que uma postura política para o sofrimento combina com a ética da pesquisa; e a Luiz Augusto Monnerat Celes, por me dar liberdade para ter perguntas ingênuas, mas ensinar que para tentar qualquer resposta, o estudo atento é imprescindível. 
Ao NEGENPSIC - Núcleo de Estudos de Gênero e Psicologia Clínica -, na figura de cada um dos que me ajudaram, pessoalmente ou através de suas marcas intelectuais. Este trabalho é fruto de uma construção coletiva. Ao meu irmão mais velho no grupo, o Bill, por sempre prestativo me guiar nas dificuldades.

À Miriam Pondaag - coordenadora da Casa da Mulher Brasileira -, à Maísa Guimarães - gerente dos NAFAVD's -, aos participantes da Rede de Proteção às Mulheres do DF e Entorno e aos policiais atuantes nos PROVID's da Ceilândia e de Taguatinga. Em um momento difícil da pesquisa, todas essas pessoas me ajudaram ativamente e desinteressadamente na busca pelos participantes.

Aos servidores do Pró-Vítima, especialmente aos que ajudaram a pesquisa na busca pelos participantes e me concederam a possibilidade de pesquisar. Ana Paula, Caio, Flávia, Gildete, Igor, Laís, Lilian, Rita, Susy, Vieira, Valéria.

Aos participantes da pesquisa. A abertura para expor conteúdos íntimos em séries de entrevistas difíceis afetivamente precisa ser lembrada. Depois de muitas emoções e reflexões, esse trabalho só é possível pela generosidade infinita de vocês, que me ofereceram mais do que eu esperava. A forma desinteressada como contribuíram com a produção de conhecimento foi um exemplo sem igual em minha vida. 


\section{Kiss With a Fist Beijo Com o Punho}

You hit me once, I hit you back You gave a kick, I gave a slap You smashed a plate over my head Then I set fire to our bed

My black eye casts no shadow Your red eye sees nothing Your slaps don't stick Your kicks don't hit So we remain the same Love sticks, sweat drips Break the lock if it don't fit

A kick in the teeth is good for some A kiss with a fist is better than none

I broke your jaw once before I spilt your blood upon the floor You broke my leg in return So I sit back and watch the bed burn Love sticks, sweat drips Break the lock if it don't fit
Você me bateu uma vez, eu revidei Você deu um chute, eu dei um tapa Você quebrou um prato na minha cabeça Então eu coloquei fogo na nossa cama

Meu olho roxo não tem sombra Seu olho vermelho não vê nada Seu tapas não permanecem Seu chutes não me acertam Então continuamos os mesmos O amor gruda, o suor escorre Quebre a fechadura, se ela não encaixa

Um chute nos dentes é bom para alguns Um beijo com o punho é melhor que nada

Eu quebrei seu maxilar uma vez Eu derramei seu sangue no chão Você quebrou minha perna em troca Então eu sento e assisto a cama queimar O amor gruda, o suor escorre Quebre a fechadura, se ela não encaixa 
RESUMO

ARTIGO 1 - GÊNERO E TECNOLOGIA DE GÊNERO: CONSTRUÇÕES DA EXPERIÊNCIA NA SITUAÇÃO DE VIOLÊNCIA CONJUGAL ..........................15

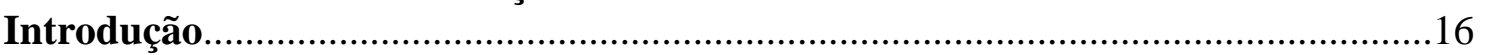

Gênero e experiência conformam as subjetividades............................................. 17

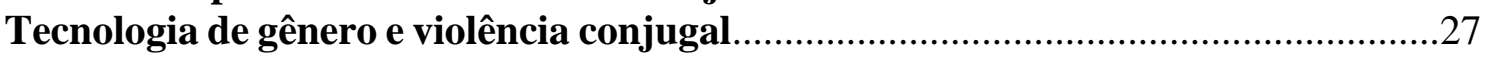

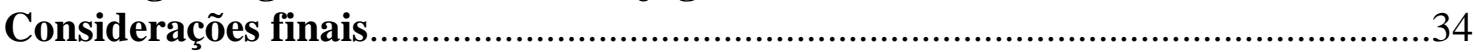

ARTIGO 2 - ROTEIROS SEXUAIS E RITUAIS CONJUGAIS: CONSTRUÇÕES

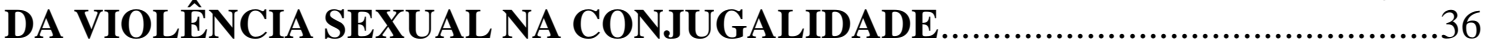

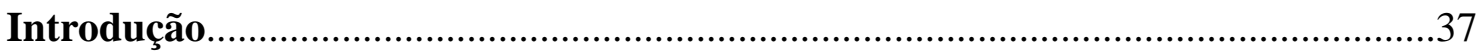

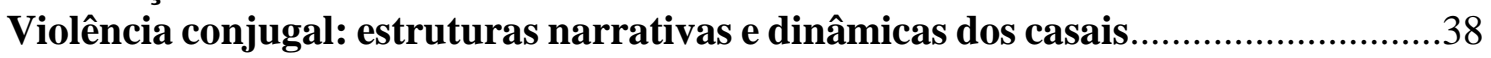

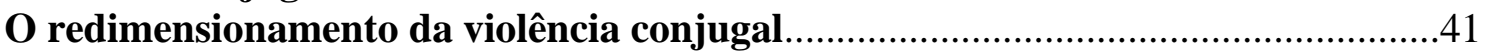

$\mathbf{O}$ ciclo da violência: uma dinâmica conjugal.......................................................44

Os roteiros sexuais e rituais conjugais: a construção da conduta sexual....................50

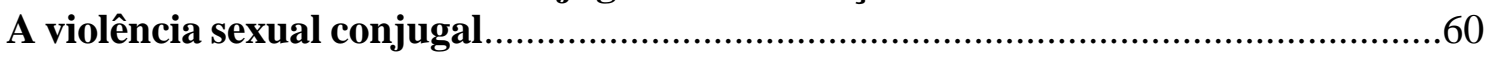

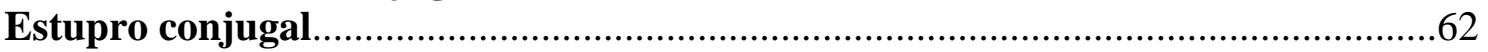

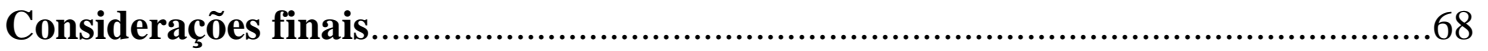

ARTIGO 3 - VIOLÊNCIA CONJUGAL: FAMÍLIA E ESTADO FAVORECEM PRÁTICAS E DISCURSOS DE GÊNERO E PODER...........................................69

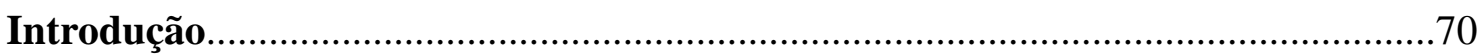

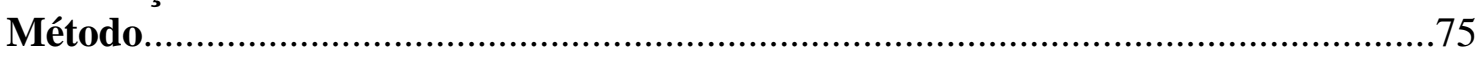

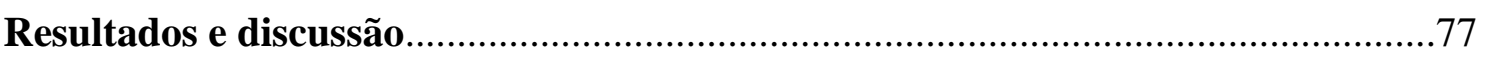

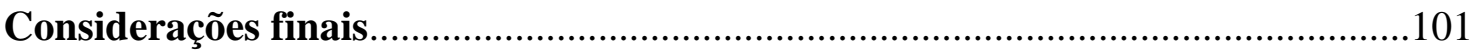

ARTIGO 4 - A VIOLÊNCIA SEXUAL NA CONJUGALIDADE: GÊNERO E PODER NOS ROTEIROS SEXUAIS E RITUAIS CONJUGAIS..........................106

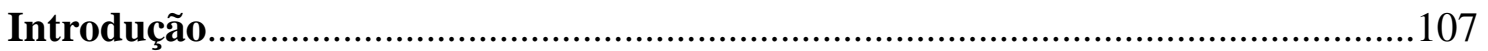

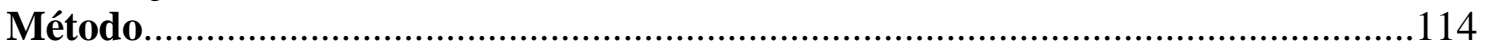

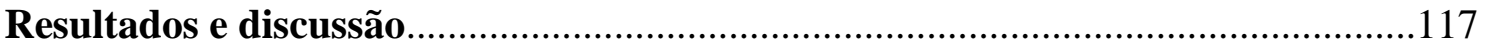

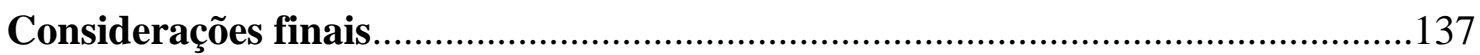

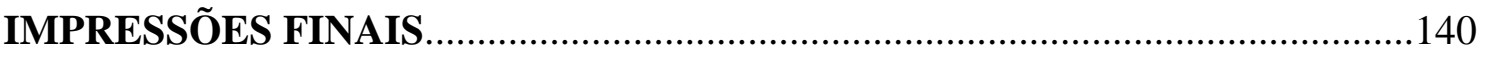

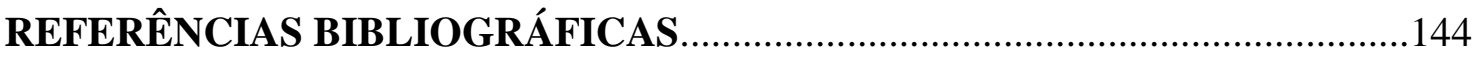

ANEXOS

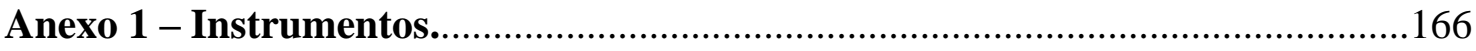

Anexo 2 - Termo de consentimento livre e esclarecido.......................................178 


\section{RESUMO}

Assis, R. G. (2015). Do estupro às flores: gênero e roteiros sexuais na situação de violência conjugal. Dissertação de Mestrado, Instituto de Psicologia, Universidade de Brasília, Brasília.

O presente trabalho apresenta artigos teóricos e empíricos, os quais contam com parte dos dados de dois estudos de caso. O objetivo da pesquisa foi identificar as construções e significações afetivo-sexuais que permeiam o exercício da sexualidade e analisar seu impacto na dinâmica de casais em situação de violência conjugal. Investigamos os roteiros sexuais, rituais conjugais e genogramas sexuais, para identificar as construções pessoais, geracionais e sociais que resultam em práticas e significações na conduta sexual dos casais. Investigamos também como as questões de gênero atravessam as experiências subjetivas, relacionais e afetivo-sexuais dos casais. Depois relacionamos as construções e significações afetivo-sexuais com as dinâmicas da violência conjugal, com vistas a compreender de que forma as práticas sexuais e as questões de gênero e poder atravessam essas dinâmicas. Os estudos de caso foram realizados com dois casais que procuraram atendimento psicossocial por conta de situação de violência conjugal com denúncia judicializada. Foram realizadas a construção do genograma familiar e genograma sexual dos casais e entrevistas semi-estruturadas para contemplar experiências de violência, casamento e sexualidade. O instrumento CTS-2 foi aplicado para acessar os dados de coerção sexual dos casais. Os resultados apontaram que as interações dos cônjuges - com a família ao longo da vida, como casal e com o estado depois da violência - constroem práticas e significações que influenciam representações, posições subjetivas e o contexto relacional da violência conjugal. Além disso, a violência sexual é ainda menos comunicada e inteligível que outras formas de violência conjugal, mas acontece com intenção do agressor e em contextos de poder e controle perpassados por dupla moral sexual, que posiciona diferentemente homens e mulheres.

Palavras-chave: gênero, violência conjugal, roteiros sexuais, sexualidade, coerção sexual. 


\begin{abstract}
Assis, R. G. (2015). From rape to bouquet: gender and sexual scripts in the intimate partner violence. Masters Dissertation, Instituto de Psicologia, Universidade de Brasília, Brasília.
\end{abstract}

This work presents theoretical and empirical articles that rely partially on data from two case studies. The aim of the research was to identify sexual-affective constructions and meanings that permeate practices of sexuality and analyze their impact upon the dynamics of couples under an intimate partner violence condition. We have investigated sexual scripts, marital rituals and sexual genograms in order to identify personal, generational and social constructions that result in practices and meanings in sexual conduct of the couples. We also investigated how gender issues permeate subjective, relational and sexual-affective experiences of couples. Then we correlate sexual-affective constructions and meanings to intimate partner violence dynamics in order to understand how sexual practices and gender issues may permeate such dynamics. We have developed case studies with two married couples that have demanded psychosocial treatment due to intimate partner violence followed by judicial complaint. Construction of family genogram and sexual genogram have been conducted plus semi-structured interviews in order to account for violence, marriage and sexuality experiences. CTS-2 tool has been applied in order to access sexual coercion data from couples. Results point that marital interactions - with family in their life course, as a couple and with the state, right after violence - construct practices and meanings that influence representations, subjective positions and relational contexts of intimate partner violence. In addition, sexual violence is even less communicated and intelligible than other forms of intimate partner violence, but they occur due the aggressor's intention and in contexts of power and control permeated by a twofold sexual moral that ascribes different roles to men and women.

Key words: gender, marital violence, sexual scripts, sexuality, sexual coercion. 


\section{APRESENTAÇÃO}

Meu interesse acadêmico pela violência conjugal surgiu em uma disciplina da graduação em psicologia da Universidade de Brasília chamada Tópicos especiais em psicoterapia, com tema Violência conjugal e intervenção psicossocial. Ela foi oferecida pela orientadora deste trabalho com seu orientando Fabrício Guimarães. A disciplina me tirou as vendas e me fez perceber um problema social a que eu era praticamente indiferente, apesar de pressentir como uma questão grave. A violência conjugal, os feminismos e as questões de gênero, desde então, tornaram-se parte de meus interesses e minha sensibilidade.

$O$ interesse acadêmico em questões que envolvem a interação entre sexualidade e violência veio posteriormente, quando trabalhei por três anos no PróVítima, Programa de Assistência Multidisciplinar a Vítimas de Violência. Entre os crimes que envolviam estupro e estupro de vulnerável, violência conjugal e feminicídio, vítimas e seus familiares relatavam aspectos da conjugalidade, inclusive das práticas sexuais, que revelavam conflitos interpessoais e sofrimento psíquico. A conduta sexual era reeditada à luz de questões que envolviam a situação de violência. Em muitos casos, as formas como se davam as agressões eram múltiplas e incluíam violência sexual, algo já indicado na literatura (Dantas-Berger \& Giffin, 2005; Kronbauer \& Meneghel, 2005; Schraiber et al., 2007).

A situação de violência conjugal é complexa, multideterminada e dinâmica. Mitos, valores, crenças e práticas compartilhadas pela sociedade influenciam a violência doméstica. Esse conjunto de práticas violentas, exercidas tipicamente em ambientes privados, pode facilitar relações com características específicas que envolvem a presença de dinâmicas interacionais de controle e poder. 
Há elementos socioculturais difundidos e valorizados - como as concepções de gênero - que favorecem relações desiguais e violentas. Uma forma de controle e exercício de poder envolve as manifestações de afeto e, de modo especial, o exercício da sexualidade. Esta pesquisa, de natureza exploratória, investigou dimensões da sexualidade de casais encaminhados ao Pró-Vítima como parte da situação de violência conjugal. Essa é uma experiência que não pode ser dissociada da sexualidade dos casais. As relações de poder que permeiam atos violentos também estão presentes no contexto das práticas sexuais. Os corpos e o relacionamento são os mesmos, e não há como torná-los a-históricos, ou seja, é impossível separar a experiência violenta da sexual.

A prevenção e o tratamento da violência conjugal requerem perspectivas integradoras, relacionais e sistêmicas, para dar conta da multiplicidade de aspectos que envolvem a violência na conjugalidade (Falcke, Oliveira, Rosa \& Bentancur, 2009). Os estudos sobre a violência precisam conter uma diversidade de dimensões para que a complexidade da questão seja contemplada. A sexualidade é uma dimensão importante no contexto da pesquisa acerca das relações conjugais violentas. Nesse sentido, esta pesquisa visou identificar as construções e significações afetivo-sexuais que permeiam o exercício da sexualidade e analisar seu impacto na dinâmica de casais em situação de violência conjugal. Os objetivos específicos foram:

- investigar como as questões de gênero atravessam as experiências identitárias, relacionais e afetivo-sexuais de casais em situação de violência conjugal;

- investigar os roteiros sexuais, rituais conjugais e genogramas sexuais para identificar as construções pessoais, geracionais e sociais que resultam em significações para o exercício da sexualidade dos casais; 
- relacionar as construções e significações afetivo-sexuais com as dinâmicas da violência conjugal, a fim de compreender de que forma as práticas sexuais e as questões de gênero e poder atravessam essas dinâmicas.

O trabalho está dividido em quatro artigos, dois teóricos e dois empíricos. Todos contribuem para a discussão da relação entre questões de gênero, violência conjugal e práticas sexuais e seus significados. Elementos familiares e sociais que envolvem a construção de posições subjetivas e roteiros sexuais foram contemplados para estruturar a reflexão acerca da violência conjugal.

O primeiro artigo discute as construções de gênero e suas relações com a violência conjugal. Os conceitos de gênero e experiência de Joan Scott possibilitam um ponto de vista relacional e subjetivo. A perspectiva semiótica de gênero de Teresa de Lauretis é retomada, abordando-se os conceitos de interpelação e tecnologia de gênero. Compreende-se que a violência conjugal tanto é favorecida por representações tradicionais de gênero quanto favorece posições subjetivas condicionadas pela violência. A conduta violenta na conjugalidade funciona como tecnologia de gênero.

O segundo artigo aponta a violência conjugal inserida em uma dinâmica relacional e em contexto cultural. Parte-se do pressuposto de que as manifestações de violência estão imbricadas em outras dimensões da conjugalidade, especialmente a sexualidade. A experiência sexual conjugal é percebida como espontânea, íntima e privada ao casal. Apesar disso, ela também apresenta construções a partir dos cenários culturais, interpessoais, intrapsíquicos e históricos que roteirizam e ritualizam a conduta sexual.

A violência sexual do casal, inclusive o estupro, é considerada em seus contextos atitudinais, discursivos e dinâmicos. Ela não é, necessariamente, disruptiva, ou seja, não interrompe a conjugalidade nem tampouco a sexualidade. Partimos do pressuposto de que existe uma interação da violência sexual conjugal e de outras formas 
de manifestação da violência: a primeira conta com elementos da dinâmica relacional de modo que suas práticas e significações favoreçam a situação de violência conjugal.

O terceiro e o quarto artigo apresentam parte dos dados de estudos de caso realizados com dois casais em situação de violência. $\mathrm{O}$ terceiro artigo problematiza as construções e significações das dinâmicas da violência conjugal, visando compreender de que forma as questões de gênero e poder atravessam essas relações. As categorias analisadas são: violência conjugal e construções de poder; família e interferência conjugal; e justiça e reposicionamento da conjugalidade violenta. As interações dos cônjuges - entre si, com a família ao longo da vida e com o Estado depois da violência — constroem práticas e significações que influenciam as representações, as posições subjetivas e o contexto relacional da violência conjugal.

O quarto artigo explora as relações entre as construções e significações afetivosexuais e as dinâmicas da violência conjugal, a fim de entender de que forma as práticas sexuais e as questões de gênero e poder atravessam essas relações. É analisada a categoria construções da sexualidade e violência conjugal. A violência sexual é um tabu, aqui discutido levando em conta contextos de poder e controle perpassados por uma dupla moral sexual, que diferencia representações de homens e mulheres. 


\section{ARTIGO 1 \\ GÊNERO E TECNOLOGIA DE GÊNERO: CONSTRUÇÕES DA EXPERIÊNCIA NA SITUAÇÃO DE VIOLÊNCIA CONJUGAL}

Resumo: As construções de gênero estão imbricadas na situação de violência conjugal. O objetivo desse artigo é apontar como tal violência constrói representações de gênero e funciona como tecnologia de gênero. Aproximações aos conceitos de gênero e experiência de Joan Scott são realizadas para discutir a perspectiva relacional e subjetiva do papel de homens e mulheres. A perspectiva semiótica de gênero estruturada por Lauretis será retomada nos conceitos de interpelação - em que a pessoa assume representações ideológicas como suas próprias - e tecnologia de gênero - que considera a introjeção ou afetação pelos indivíduos como efeito de discursos ou representações. A violência conjugal é uma tecnologia de gênero, pois favorece posições subjetivas de gênero que são reproduzidas e condicionadas pela situação de violência.

Abstract: This article examines gender constructions and their relations to the intimate partner violence condition. The aim is to indicate how such violence construct gender representations and hence functions as technology of gender. We develop approaches to Joan Scott's concepts of gender and experience in order to examine the relational and subjective perspective on the role of men and women. We resume the semiotic perspective on gender structured by Lauretis through the concepts of interpellation - in which individual assumes representations as his or her own - and technology of gender - that considers introjection or affectation by individuals as an effect of discourses and representations grounded on power. Intimate partner violence is pointed as a technology of gender because it supports particular subjective roles of gender conditioned by the violence condition. 


\section{Introdução}

A violência é organizada e até facilitada pelas representações e experiências desiguais que marcam as relações entre homens e mulheres. A violência conjugal é uma violência de gênero (Diniz, 2011, 2013; Diniz \& Pondaag, 2004, 2006; Guimarães, 2009; Pondaag, 2009; Narvaz \& Koller, 2006). Ao mesmo tempo, circularmente, a conjugalidade violenta favorece posições subjetivas que engendram e reificam representações tradicionais de gênero, ou seja, ela funciona como uma tecnologia de gênero.

A violência conjugal é complexa, multideterminada e dinâmica. Um dos elementos de análise para a discussão sobre esse tipo de violência são as práticas e representações, discursivas ou não, conscientes ou não, que permeiam os papéis sociais atribuídos aos homens e mulheres. As concepções de gênero e o entendimento de seus impactos na construção de papéis sociais sexuais eram inalcançáveis antes do surgimento das epistemologias feministas. Tais epistemologias trazem contribuições fundamentais para a reflexão sobre a violência conjugal e a sexualidade.

Esta reflexão tratará da construção de representações do ser homem e do ser mulher para compreender os corpos e suas práticas como inseridos em uma cultura e, consequentemente, como historicamente construídos. Esse processo é fundamental para a compreensão da construção das conjugalidades e, de modo especial, das conjugalidades marcadas pela presença de violência.

A contextualização do conceito de gênero parece ser fundamental para a consequente desnaturalização da experiência corporal e das práticas que envolvem a experiência nas relações. Duas estudiosas serão pontualmente discutidas tendo em vista suas contribuições conceituais para a compreensão do sistema sexo-gênero. Elas são Joan Scott $(1995,1998)$ - que será retomada com relação ao próprio conceito de gênero e suas análises, além da noção de experiência - e Teresa de Lauretis $(1994,2007)$ - que 
traz contribuições acerca das noções de interpelação e tecnologia de gênero, cujo conceito se refere a posições subjetivas que são construídas a partir de uma representação de gênero.

\section{Gênero e experiência conformam as subjetividades}

O conceito de gênero é definido por Scott (1995, p. 86) como: "um elemento constitutivo de relações sociais baseadas nas diferenças percebidas entre os sexos". O enfoque dado aos relacionamentos que se dão entre homens e mulheres para a construção das diferenças é evidente. Nessa perspectiva, as mulheres não podem ser compreendidas sem a devida análise do funcionamento dos homens que com as mulheres se relacionam. Além disso, as mulheres e os homens não podem ser objeto de análise sem que sejam pensados como pessoas em relação. Os significados do que é ser mulher e do que é ser homem e de como se dá a interação deles só se constituem, organizam e estabelecem nas relações sociais entre os sujeitos que experienciam suas identidades nos termos das diferenças sexuais.

A relação entre um homem e uma mulher é pautada e marcada por tais diferenças sexuais. Nesse contexto, é possível que se compreenda que ela deve ser fiel e que ele possa ser infiel contanto que não traga problemas de fora de casa para dentro de casa. A princípio, a falta de reciprocidade no relacionamento é marcada por qualificadores específicos associados às diferenças sexuais. A mulher geralmente é estigmatizada quando faz sexo com muitas pessoas ou fora do casamento, enquanto o homem geralmente não sofre sanção quando faz sexo com muitas pessoas ou fora do casamento, contanto que não traga problemas para casa.

Os arranjos relacionais da conjugalidade e das sanções sociais descritos coincidem com significados específicos de ser homem e de ser mulher. A diferença sexual é percebida socialmente como se o homem desejasse mais as relações sexuais e 
fosse menos capaz de se conter para sua satisfação. A mulher, por outro lado, é vista como alguém que tem sua satisfação associada à sua segurança no relacionamento (Giacomozzi \& Camargo, 2004). As identidades que lhes são facultadas organizam e estabelecem, portanto, características relacionais.

Os termos da diferença sexual são tomados como naturalizados em uma relação de oposição binária rígida (Lauretis, 1994, 2007; Rodrigues, 2010; Scott, 1995). Assim, parece na convivência que se tem com as representações de homens e mulheres, que os sujeitos são naturalmente posicionáveis nas categorias que essas representações contemplam. Se homens são percebidos como naturalmente mais propensos a liderança e a manifestações corporais agressivas e mulheres mais propensas a atividades domésticas e falar muito, essas representações também constroem práticas e percepções que façam notar mais homens como bons líderes e mais mulheres como melhores em limpar a casa. Isso não quer dizer que tenha algo nas diferenças percebidas entre os sexos que a priori esteja na carne do homem ou da mulher. Pelo contrário, as diferenças sexuais são já e desde sempre construídas e percebidas em contextos históricos e sociais. Além de os gêneros fundamentarem as relações sociais tendo como base as diferenças sexuais percebidas e construídas, Scott $(1995$, p. 86) levanta que o conceito de "gênero implica quatro elementos interrelacionados".

Os primeiros elementos são os símbolos que são disponíveis na cultura e que evocam representações com múltiplos significados (Scott, 1995). As mulheres compareciam - na literatura do período romântico brasileiro, mas não só nela - como virtuosas, intocáveis, sem desejos próprios, puras ou imorais, voluptuosas, causadoras de tentação, pecaminosas. As mulheres angelicais e as demoníacas eram possibilidades de representação de personagens femininos na literatura, ou seja, as mulheres eram representadas através de múltiplas possibilidades significativas, porém limitadas ao seu dualismo. Assim, a partir das experiências ou expectativas relacionais, sujeitos 
identificáveis com traços de mulher poderiam ser interpretadas como angelicais - caso o sentido interpretativo seja um - ou diabólicas - caso seja outro.

Os segundos elementos são os conceitos normativos que fazem emergir as interpretações do sentido dos símbolos, os quais estabelecem parâmetros e limitações para as possibilidades metafóricas (Scott, 1995). Voltando à mulher angelical, os anjos símbolos na cultura - podem ter muitas possibilidades metafóricas, podendo ser retomados como: tediosos (pois ficam no céu sem fazer nada), ajudantes (pois são guardiões e intervêm), belos (pois tem aparência diferenciada), observadores (pois ficam atentos aos passos humanos acompanhando-os) e muitos outros. Apesar disso, os símbolos já são retomados para a circunscrição do feminino com os contornos de conceitos normativos que estabelecem as experiências e expectativas relacionais com as mulheres. Os conceitos normativos restringem as possibilidades e direcionam para poucos sentidos em fluxos interpretativos rígidos. As mulheres podem ser interpretadas como sendo angelicais apenas caso não demonstrem desejos próprios e não estimulem o outro, ou seja, o símbolo é múltiplo, mas os conceitos normativos organizam o sentido para as experiências relacionais.

Scott (1995, p. 86) esclarece, sobre o gênero, que os conceitos normativos "são expressos nas doutrinas religiosas, educativas, científicas, políticas ou jurídicas e tomam a forma típica de uma oposição binária fixa, que afirma de maneira categórica e inequívoca o significado do homem e da mulher".

Essa forma de representação que já contêm o seu sentido determinado inequivocamente é apresentada como se fosse natural, ou seja, não como se a noção de norma fosse construída, mas como se fosse objeto de um consenso a-histórico e não social. Apesar de tal apresentação, percebe-se a noção de fixidez ou de naturalidade das diferenças percebidas entre os sexos atravessada pela relação binária entre homens e mulheres como construída, historicamente diversa e fruto de diversos conflitos, 
subjetivos e interpessoais. Assim, um homem a quem foi ensinado que ele não deveria expressar o que sente pode ser extremamente emotivo e falar constantemente sobre suas sensações. Supõe-se inclusive que a constante reafirmação e reificação dos gêneros como naturais e heteronormativos nas instituições e aparatos culturais seja um indício de que é preciso muita força para que as diferenças sexuais normativas sejam percebidas ilusoriamente como consensuais, naturais e inflexíveis (Scott, 2011). Ainda assim, a diferença comparece e é sublinhada como fora da regra pelos conceitos normativos da cultura, isto é, homens ou mulheres que não se comportem convenientemente são depreciados ou desprivilegiados relacionalmente, compreendidos como menos humanos. Não é difícil imaginar, por exemplo, nas situações que envolvem os casais em situação de violência doméstica, que um homem desempregado seja interpretado como alguém que não consegue sustentar a família (menos-provedor) e uma mulher que não tenha controle dos filhos seja compreendida como uma má mãe (menos-materna).

Os terceiros elementos das relações de gênero são as instituições e organizações sociais. O gênero é construído dentro dos modos de organização da sociedade. Assim como o parentesco fundamenta relações de gênero, este também é construído no mercado de trabalho, na educação, no sistema político (Scott, 1995).

Se as mulheres são profissionais praticamente exclusivas em profissões como professoras pré-escolares e empregadas domésticas, isso pode estar relacionado às respectivas representações de mulheres como cuidadoras e as que realizam atividades domésticas. Se os homens são praticamente exclusivos em profissões como ajudantes de pedreiro e seguranças pessoais, isso pode estar relacionado às respectivas representações dos homens como fortes e protetores. Isso não quer dizer que a relação é de causalidade entre as práticas das instituições e organizações sociais e as representações organizadas pelos conceitos normativos, mas é evidente que esse é um dos elementos que constituem as relações sociais que organizam os significados 
atribuídos às diferenças sexuais. É importante frisar que dizer quem é apto ou não em uma sociedade para ser educador em uma sala de aula ou segurança em uma festa revela práticas sociais muito distantes das concernentes a uma separação entre quem tem pênis e quem tem vagina, mas os aparatos culturais e construções sociais fazem com que práticas como essas sejam não só naturalizadas como normatizadas.

O quarto elemento apontado por Scott (1995) são as identidades subjetivas. As relações que fundam, organizam e estabelecem os gêneros se dão também em contextos históricos, sociais e culturais específicos que propõem posicionamentos subjetivos específicos. Assim, quem nasce já é demandado a partir de uma posição em que é implicado, seja a de homem ou a de mulher. As lições sobre o que é ser homem ou o que é ser mulher não são transmitidas como aquelas sobre a Guerra do Paraguai, ocasionalmente e provavelmente de maneira formal. As lições sobre o binarismo sexual são experienciadas constantemente nas relações atravessadas nos símbolos e representações em todas as instituições e organizações. Assim, a identidade e o pertencimento ao masculino ou ao feminino são constantemente reafirmadas e reificadas não só como algo que existe em uma cultura exterior, mas como algo que é uma experiência identitária de si. Quando um homem diz que "os homens não conseguem segurar os próprios instintos e por isso traem mais", ele está propondo uma crença sobre a motivação da traição de outros homens, mas implicitamente ele está falando da própria instabilidade corporal. Da mesma forma, quando uma mulher diz que "as mulheres devem ser santas na rua e putas na cama", ela está propondo um valor que opera para dizer qual mulher se comporta bem e qual mulher se comporta mal, mas está tratando de valores que perpassam as vivências dos próprios comportamentos, avaliados a partir de um conjunto de ideais, valorados positiva ou negativamente, pertencentes à distinção binária público-privado. 
Os quatro elementos - símbolos, conceitos normativos, instituições e organizações sociais e identidades subjetivas - estão diretamente relacionados entre si e constituem o gênero, isto é, são dados de uma realidade social. Eles são evidentemente construídos em um contexto histórico e sociocultural que favorece e possibilita relações sociais e identidades pessoais específicas. Os símbolos e os sentidos selecionados normativamente, as instituições e organizações e as identidades pessoais posicionam a experiência do sujeito que percebe a si e aos outros dentro das categorias de gênero que reconhece, como homem e mulher.

O conceito de gênero proposto por Scott (1995, p. 86) também contempla "uma forma primária de dar significado às relações de poder”. Essa acepção pode ser reescrita como "o gênero é o campo primário dentro do qual ou por meio do qual se articula o poder" (Souza \& Carrieri, 2010, p. 67). O gênero é compreendido como uma forma de apontar o sentido das interações humanas, ou seja, de organizar a circulação do poder em relações sociais complexas. As percepções das diferenças sexuais precisam ser compreendidas a partir de uma experiência específica com o poder.

Refletir sobre as percepções das diferenças sexuais é relevante, mas somente se as respectivas construções puderem ser analisadas em seus aspectos relacionais. Pensar, por exemplo, na interação de mulheres e homens precisa passar por analisar como se dão as relações de poder entre eles. As hierarquias e valores se dão em processos de interação e construção que não podem ser isolados de como o poder circula e opera nas relações.

O poder se dá dos grupos mais restritos - como os conjugais - para o conjunto do corpo social e vice-versa. Assim, as grandes representações que envolvem dominação são efeitos sustentados por todas as relações de poder (Foucault, 2013). Vários grupos pesquisados, indicando estruturação do conjunto social sobre a questão, tem a percepção de que na situação de violência doméstica, a mulher gosta de apanhar 
(Brandão, 2006). A face cruel dessa representação é a responsabilização da mulher pela violência que lhe é acometida na conjugalidade (Cavalcanti, Gomes \& Minayo, 2006; Lamoglia \& Minayo, 2009). Lamoglia e Minayo (2009), em estudos em delegacia do interior do Rio de Janeiro, apontam que:

Geralmente quando contam suas agressões, os maridos costumam dizer que: "primeiro, avisam", “procuram conversar" e se não são obedecidos, não agüentam e "bate”. Ou seja, a mulher foi a culpada de seu "rompante". Por isso, os agressores consideram que o comportamento e as atitudes das mulheres estão sempre aquém do ideal que preconizam ou desejam, colocando-se no lugar de guardiões de um tipo de moral que precisam garantir e controlar. (p. 602)

$\mathrm{Na}$ própria conjugalidade, um grupo mais restrito, a mulher vivencia essas justificativas do outro por ter sido violentada, seja com a função educativa, moralizadora ou controladora, seja porque gosta de apanhar. As experiências que envolvem a normatividade para manejar o sentido daquilo que é representado - como a violência, ou o papel do homem e da mulher - são construídas em contextos históricos e socioculturais específicos. Essa forma de compreensão da violência não se dá porque quem gosta de apanhar possui vagina e quem bate porque pode educar ou corrigir possui pênis. A forma de se relacionar e dar sentido a isso é construída na experiência e facilita posições desiguais nas interações dos diferentes, mulheres e homens.

O poder se articula nas situações de violência, na divisão entre funções masculinas e femininas e nas doutrinações do corpo, mas não só nessas circunstâncias. As construções de gênero não são retiradas do corpo como máscaras. Elas podem ser redimensionadas, mas nunca completamente destituídas da história do corpo e das experiências. Assim, o poder que se articula dentro e por meio do gênero circula em todas as interações, está presente em todas as experiências, como um aspecto fundamental da identidade que é redimensionado por toda a vida. 
Um conceito importante para pensar a noção de redimensionamento da identidade é o de experiência para Scott (1998), cuja reflexão é retomada a partir das metodologias referendadas pelas pesquisas históricas. Segundo ela, explicando uma forma como o campo da história se utiliza da experiência para a produção:

o conhecimento é adquirido através da visão; a visão é uma apreensão direta de um mundo de objetos transparentes. Nesta conceitualização o visível é privilegiado; escrever é, portanto, colocado a seu serviço. Olhar é a origem do saber. Escrever é reprodução, transmissão - a comunicação do conhecimento adquirido através de experiência (visual, visceral). (Scott, 1998, p. 300)

A visão relacionada aos objetos transparentes os posiciona de forma que a apreensão do objeto se dá efetivamente pelo olhar, ou seja, olhar (perceber) é uma forma de apreensão direta e inequívoca do objeto. Assim, a experiência é valorizada em detrimento da interpretação, já que quem experiencia tem seu relato tomado como verdadeiro - ou transparente. O mundo dos objetos é transparente àquele que vê, ou seja, a transparência é a característica de inteligibilidade daquele que olha e posteriormente relata. Olhar é já vivenciar a experiência da realidade como ela é, na perspectiva de parte desse campo da história.

Pode se compreender a experiência como um acontecimento para um sujeito que percebe aquilo que olha/sente. A experiência pode, nesses termos, ser descrita e legitimada por quem a enuncia. É como se alguém pudesse dizer algo parecido com: “Eu vi, eu estive lá.” Esse tipo de compreensão evidencia aquilo que se vê como pouco questionável.

A experiência, por outro lado, pode ser pensada como uma forma de os sujeitos perceberem a partir de sua posição. Como propõem Scott e Navarro-Swain (2011, p. 5), "a experiência não é algo que simplesmente temos, mas que interpretamos"1. Ou seja, a

\footnotetext{
${ }^{1}$ Tradução livre do autor do artigo. Grifo da autora na fonte citada.
} 
experiência não é compreendida pela autora como pela lógica do olhar que qualifica o objeto como analisado sem equívocos, já que quem descreve o objeto de fato esteve presente, interpretou-o. A experiência é compreendida como um algo que é significado por quem a percebe, que tem um sentido determinado por quem a descreve (Scott, 1998). A descrição daquilo que se olhou revela tanto o objeto visto quanto a posição subjetiva de quem olhou.

Um homem, em uma determinada relação sexual com sua companheira, pode relatar que ela não queria cumprir com suas obrigações de esposa ou namorada e que ele teve que convencê-la a lhe dar o que é seu direito. Uma mulher, em uma determinada relação sexual com seu companheiro, pode relatar que, por não ter vontade de fazer sexo, foi violentada sexualmente. Os dois podem ser membros do mesmo casal. Apesar de a relação sexual, a vivência experienciada, ter sido a mesma, os dois obviamente têm posições subjetivas completamente diferentes que implicam em significados e sentidos da interpretação diferentes e divergentes. A experiência pode ter sido ao mesmo tempo, com os mesmos corpos, na mesma relação, no mesmo cenário etc., mas as presenças frente à experiência geram interpretações multiplicadas pelas posições sujetivas.

A experiência é uma forma de posicionar os sujeitos. Além de subsidiar a interpretação de uma realidade que o sujeito constrói, a própria subjetividade é construída a partir daquilo que ela experiencia. Nas palavras de Scott (1998, p. 304), precisamos nos referir aos processos históricos que, através do discurso, posicionam sujeitos e apresentam suas experiências. Não são indivíduos que têm experiência, mas sim os sujeitos que são constituídos pela experiência.

Um segundo aspecto da experiência é que ela constitui um sujeito ou uma posição subjetiva. Ainda com o casal que teve a relação sexual com múltiplas interpretações em vista, pode-se dizer que a experiência e o seu respectivo relato posicionam os sujeitos que estabelecem relação. Hirigoyen (2006), em estudo sobre a 
violência doméstica, aponta que a mulher pode ser compreendida como tendo obrigações no que tange à sexualidade e o homem pode ser compreendido como quem pode cobrar essas obrigações e fazer valerem, sendo o sexo um direito para ele e um dever para ela. $\mathrm{O}$ homem pode ser considerado ativo em sua busca por práticas sexuais e a mulher assujeitada. A vontade da mulher pode ter menos valor do que a do homem. Esses exemplos de lugares criados a partir de experiências relacionais com o cônjuge em um relacionamento sexual podem ou não acontecer. Porém, essas possibilidades de posições subjetivas indicam que ser homem ou ser mulher tem distintos significados que são construídos no contexto histórico e relacional dos próprios relacionamentos.

Qualquer experiência que produz posições subjetivas produz papéis de gênero, produz lugares normativos de homens e mulheres. Assim, uma discussão que pode nortear a questão de como a violência conjugal influencia as concepções de gênero pode ser: Quais representações de gênero revelam as interpretações advindas das experiências? e Quais posições subjetivas de gênero as experiências constroem? Ir na direção das questões apresentadas ao entrar em contato com o relato da experiência implica questionar não o que o sujeito viu, como se ele pudesse binariamente estar dizendo a verdade ou não. Questionar os relatos a partir dessas perguntas é tentar encontrar a construção histórica e relacional do sujeito que relata, as suas construções interpretativas das experiências e suas posições subjetivas e identitárias.

A leitura feita da perspectiva de Scott sobre o gênero e a experiência possibilita a reflexão de que os sentidos, interpretações e representações investidos nas diferenças sexuais se dão no contexto das relações. As significações e posições identitárias são constituídas e instituídas nas interações que se dão entre os pares, inclusive nas relações de poder em que há a violência conjugal, geralmente relações hierárquicas e com enrijecimentos provenientes dos elementos tradicionais de gênero. A violência conjugal 
passará a ser discutida como uma tecnologia de gênero, que posiciona os sujeitos a partir da experiência na situação violenta.

\section{Tecnologia de gênero e violência conjugal}

Pode-se traçar algumas relações entre gênero e violência conjugal. A violência que se dá nas relações íntimas opera como tecnologia de gênero. Lauretis (1994, 2007) propõe conceitos que organizam a relação que será feita entre tecnologia de gênero e violência conjugal. Serão retomados o seu conceito de gênero ligado à representação, a respectiva interpelação feita ao sujeito para que ele se posicione e a concepção de tecnologia, desde a tecnologia sexual à tecnologia de gênero.

A compreensão de gênero em Lauretis(1994, 2007) é perpassada por um aspecto importante do gênero, que é sua construção pela via dos signos ou significados, ou seja, por uma concepção semiótica. Lauretis (2007, p. 204) afirma: "Eu especulo que a sexualidade é uma instância específica de semiose, o processo geral de formação do signo e do conteúdo, um processo que articula e estrutura subjetividade à significação social e realidade material.’2

Enquanto para Scott (1998) o enfoque poderia ser o do sentido e da experiência, Lauretis (1994, p. 212) aponta para a noção de representação: "O sistema de sexogênero, enfim, é tanto uma construção sociocultural quanto um aparato semiótico, um sistema de representação que atribui significado (identidade, valor, prestígio, posição de parentesco, status dentro da hierarquia social etc.) a indivíduos dentro da sociedade.”

Lauretis (1994, p. 217) acredita que: “a construção do gênero é o produto e o processo tanto da representação quanto da auto-representação.”. O gênero, portanto, é produzido nessa rede de significações das atribuições que permeiam as posições

\footnotetext{
2 Tradução livre do autor do artigo.
} 
discursivas subjetivas. Os significados atribuídos a homens e mulheres se instituem e constituem social e relacionalmente.

Há uma concepção tradicional de gênero de que o homem é capaz de desejar sexualmente, às vezes incontrolavelmente, e a mulher é objeto de desejo e deve exercer várias práticas para se tornar desejável (Carvalho, 2003). No Código Penal Brasileiro, antes da Lei $\mathrm{n}^{\mathrm{o}} 12.015$ de 07 de agosto de 2009, o estupro era tipificado quando realizado pelo homem e sofrido pela mulher. Enquanto isso, a violência sexual realizada pela mulher contra o homem era considerada atentado violento ao pudor. $\mathrm{O}$ homem poderia ser ativo, mas não passivo no crime de estupro. A mulher poderia ser passiva, mas caso fosse ativa em violência sexual, a tipificação não poderia ser a mesma. Um elemento legal supostamente tratando igualmente os cidadãos claramente referenda a existência de uma tipificação criminal específica para o homem. Associada com uma concepção de homem, que é quem deseja, e com a de mulher, que é alvo, o crime que o alvo do desejo é capaz de cometer não poderia envolver o seu desejo. A atenção dada aqui não é às práticas dos juizados criminais em seu processo, mas às possibilidades semióticas envolvidas nos textos legais. Ela, a mulher, atentaria contra o pudor, ou seja, contra a moral e os bons costumes, caso seu desejo resultasse em prática violenta, se é que sua prática adviria de desejo, de acordo com esse tipo de representação. Os aparatos sociais, culturais e relacionais significam as representações dos corpos que são virtualmente desejantes ou desejados, sendo que os sujeitos são interpelados em suas percepções identitárias a agir de forma correspondente.

Outro conceito retomado por Lauretis (1994) é o de interpelação, descrito por Althusser (1992) ao tratar da ideologia. Esta interpela os indivíduos referidos já como sujeitos. Os indivíduos com contornos livres e abstratos são interpelados já em sua relação de sujeitos com relações imaginárias entre a ideologia que lhes posiciona subjetivamente (Althusser, 1992). Interpelação é “o processo pelo qual uma 
representação social é aceita e absorvida por uma pessoa como sua própria representação, e assim se torna real para ela." (Lauretis, 1994, p. 220).

A representação envolvida por ideologia da mulher como a pessoa mantenedora ou cuidadora da família e do lar afeta diretamente a sua experiência com a violência doméstica. Por um lado, um dos aspectos para que a violência continue ocorrendo aponta que ela é interpelada a não romper a relação violenta porque ela não pode separar a família, seja pela possibilidade de os filhos sofrerem pela ausência do pai, seja pelo casamento que ela percebe como responsabilidade dela, mesmo que tenha vários indícios de sua impossibilidade de controlar o marido violento. As relações que os sujeitos experienciam os convidam a uma posição subjetiva que já foi amplamente construída, mas que é reificada ou questionada a cada interação e percepção. No caso do gênero, esse interpela os sujeitos que se posicionam a partir dos lugares representacionais que lhes são possíveis ou factíveis.

O conceito de interpelação é útil na medida em que informa que o sujeito é chamado a uma representação subjetiva, tendo ou não consciência de sua posição, e certamente sem ter consciência do processo que o levou até lá. O gênero é forma primária de dar sentido às relações de poder (Scott, 1995). Ele interpela os indivíduos a relações sociais em que as diferenças se transformam em desigualdades, como apregoam as feministas. As representações de gênero podem iluminar aspectos relevantes da violência doméstica. Para a consideração da violência conjugal como uma tecnologia de gênero, faz-se necessário rever alguns fundamentos conceituais.

Lauretis (1994) propõe que retomemos a concepção foucaultiana de tecnologia sexual em que as diferentes produções culturais e sociais constituem e instituem a sexualidade. Esta é percebida como sendo do âmbito privado e extremamente particular, do indivíduo ou dos envolvidos nas práticas sexuais, mas vários aparatos disponíveis na cultura a influenciam. Foucault (2013, p. 114-115) aponta quatro conjuntos estratégicos 
que "desenvolvem dispositivos específicos de saber e poder a respeito do sexo" a partir do século XVIII. São eles: 1) a histerização do corpo da mulher, 2) a pedagogização do sexo da criança, 3) a socialização das condutas de procriação e 4) a psiquiatrização do prazer perverso.

A noção de tecnologia, em todos esses quatro grandes conjuntos, envolve dispositivos de saber e poder que se dão também por meio de relações de poder ou relações hierárquicas. A hierarquia diferenciada entre médicos, psiquiatras, professores, pedagogos, juízes, padres etc. proporciona uma interação específica daqueles que deles dependem ou os percebem como autoridades. Mesmo que o poder tenha circulação entre os participantes na interação, as tecnologias e seus dispositivos relacionais continuam reverberando, constituindo e instituindo posições subjetivas a partir da sexualidade.

Um dos aspectos que permeia a dinâmica dos casais na contemporaneidade é a conjugalidade ser avaliada pela sua vida sexual (Diniz, 2009; Férez-Carneiro, 2012). Há uma série de aparatos culturais que aponta que quanto mais e melhor um casal transa, mais eles são bem avaliados como felizes, saudáveis, em bom relacionamento etc. As relações conjugais violentas são relações que envolvem poder e, em muitos casos, relações hierárquicas enrijecidas. Nesse contexto, esse tipo de avaliação pode contextualizar uma experiência normalizada de violência sexual, seja por meio de coerção e, em muitos casos, até estupro. Isso porque a proposição de que os casais têm que praticar sexo vem em relações onde muitas vezes o homem é interpelado à posição de quem deseja e a mulher interpelada à posição de objeto do desejo (Hirigoyen, 2006; Levy \& Gomes, 2008), mas a mulher que de fato não deseja pode ser violentada e o homem que tem o recurso da violência como possível na relação pode usá-lo para conseguir o que deseja. Assim, algo que é um dispositivo cultural de poder sobre os casais e sua sexualidade se torna o cenário contextual para um estímulo à violência. 
Lauretis (1994) explora, além da sexualidade, que as tecnologias sociais, como os aparatos biomédicos e produções culturais, como o cinema e as revistas, produzem apelos diferenciados de sujeitos masculinos e femininos, algo que deveria ser levado em conta na análise da produção da sexualidade. Segundo Lauretis (1994, p. 208) "assim como a sexualidade, o gênero não é uma propriedade dos corpos nem algo existente a priori nos seres humanos." O que se analisa quando se reflete sobre as tecnologias de gênero é (Lauretis, 2007):

a construção social do gênero e sua introjeção ou afetação por parte dos indivíduos, como efeito de discursos e representações que, como Foucault nos ensina, estão ancorados aos mecanismos de poder. Ou seja, eles estão imbricados nas instituições sociais, tais como família, escola, medicina, direito, linguagem, comunicação de massa, mas também em práticas culturais (literatura, arte, cinema) e nas bordas do saber-disciplinar-disciplinado como filosofia ou teoria. ${ }^{3}$ (p. 218)

As tecnologias de gênero ou os aparatos sociais para a construção de gênero se dão pelos mais diversos meios e contextos e podem ser percebidas em discursos e representações nas mais diversas relações sociais. O temo tecnologia de gênero utilizado por uma feminista teórica do cinema, a Teresa de Lauretis, pode suscitar que tecnologia remonte à aparatos eletroeletrônicos ou digitais. No caso do cinema, poderia remontar a uma obra de arte em que a construção do gênero se dá porque o espectador em uma posição relativamente passiva - mesmo considerando que também interpreta assiste algo que lhe transmite as mensagens que engendram. A verdade é que, remontando à tecnologia sexual, as tecnologias de gênero permeiam o cotidiano e as práticas discursivas ou não, conscientes ou não, dos sujeitos. Estes, interpelados por ideologias, constituem-se e instituem-se a partir de representações e auto-representações

\footnotetext{
${ }^{3}$ Tradução livre do autor do artigo.
} 
reificadas nos mais diversos âmbitos dos relacionamentos sociais, mesmo nos mais íntimos, como os relacionamentos conjugais.

Alguns contextos da violência conjugal serão oferecidos para relacioná-los às respectivas experiências que interpelam os sujeitos a posições específicas relacionadas com papéis tradicionais de gênero. As situações apresentadas onde se dá a violência conjugal não pretendem ser conclusivas - nas interpretações das descrições -, nem exaustivas - pois várias outras situações podem contextualizar engendramentos provocados por uma conjugalidade abusiva. A idéia a ser discutida é de que cada situação violenta ou grupo de situações violentas que permeiam a vida de um casal transformam cada um dos cônjuges.

Um aspecto da violência conjugal que sinaliza a produção de posições subjetivas é a significação que radicalmente caracteriza os próprios envolvidos na violência em suas representações binárias: agressor/vítima, autor/alvo, dominador/submisso etc. As posições decorrentes inferem tratamentos diferentes na relação conjugal, além de nos serviços de saúde e segurança (Sarti, 2009; 2011). As diferenças são transformadas em desigualdades hierárquicas na situação de violência entre homem e mulher. Das diferenças nas expectativas de gênero decorrem posições subjetivas diferenciadas. Às mulheres, possibilitam a instauração da mágoa e do ressentimento. A mulher torna-se dependente, passiva, o que sugeriria condição inferior à masculina. (Magalhães, Araújo \& Schemes, 2013; Santos \& Izumino, 2005; Silva, Coelho \& Caponi., 2007)

A violência conjugal caracteriza-se como tecnologia de gênero pela própria experiência violenta e pela relação na qual se dá a agressão. Os papéis destinados pela sociedade aos homens e às mulheres são de dominação/atividade e submissão/passividade respectivamente (Pondaag, 2009; Monteiro \& Souza, 2007). Os papéis - de agressor e vítima - são facilitados e construídos a partir da violência conjugal, mesmo que não tenham necessariamente surgido nessa situação. Assim, a 
violência conjugal introduz na relação um conjunto de representações associados ao masculino e ao feminino que constroem contornos específicos aos gêneros. As posições subjetivas se concretizam relacionalmente e circunscrevem a interação, delimitando-a a uma maior rigidez nos papéis tradicionais de gênero.

Outro aspecto da conjugalidade violenta que produz posições subjetivas associadas a representações tradicionais de gênero são as situações em que há possibilidades de rompimentos ou denúncias. Uma das características comuns aos homens em situação de violência conjugal é o comportamento controlador (Ravazzola, 2005; Diniz, 2011, 2013). Um dos momentos de grande risco de violência, de aumento na intensidade da violência e até de homicídio é quando as mulheres decidem pedir ajuda ou se separar (Walker, 2009; Guimarães, 2009). De alguma forma, os padrões estabelecidos pela relação conjugal apregoam o homem como quem por direito deveria tomar decisões, tais como a interrupção da relação.

A violência conjugal - que tem incidências graves nesses momentos de tentativa de ruptura de uma relação violenta e geralmente com padrões enrijecidos de gênero comparece como uma tentativa de ajuste da relação. A violência assume o papel de garantir o retorno a uma condição relacional específica em que o homem tem o controle que dele é esperado. A violência tem o objetivo alcançado quando se retorna aos padrões hegemônicos de gênero que envolvem o comportamento controlador do homem, inclusive para decidir o término da relação. Qualquer um que perca o controle pode reagir de maneira adversa ou tentar reestabelecer o controle. A questão do controle nas relações violentas é que o homem, como tendência em papéis tradicionais de gênero, pode assumi-lo, inclusive violentamente. $O$ gênero parece precisar de tecnologias constantes que reafirmem o controle e reposicionem os subversivos nas relações permeadas por representações tradicionais. 
Outro aspecto da violência conjugal que cria condições para posicionar os sujeitos em papéis de gêneros é a violência sexual. Ela permanece intocada pois o exercício da sexualidade é reconhecido como um direito para o homem e um dever para a mulher (Hirigoyen, 2006). As representações que as mulheres têm, especialmente em relação à sua sexualidade, nas relações conjugais, muitas vezes perpassa a condição de objeto (Dantas-Berger \& Giffin, 2005; Diniz, 2013).

A violência sexual intraconjugal estabelece parâmetros em que a relação entre homens e mulheres os posiciona especificamente como quem têm direitos, vontades e desejos - no caso dele - e quem têm deveres, concessões e características de objeto - no caso dela. A violência sexual funciona como uma tecnologia de gênero, em que a experiência entre os dois gera significados corporais, relacionais e subjetivos específicos sobre o que é ser homem e o que é ser mulher. Além disso, esse tipo de violência e de significado estabelece condições para que outras cenas violentas aconteçam na conjugalidade.

A interpelação que é feita ao sujeito para que tenha uma percepção identitária se dá ao longo de toda a vida e de diversas formas. A violência conjugal é interpretada como uma dessas formas que fazem com que os membros do casal ocupem lugares inteligíveis a eles, ou seja, lugares que estejam dentro de sua compreensão. Muitos dos elementos que remontam a essa compreensão são as representações tradicionais de gênero, que remontam à compreensão, dentro do casal, do que é ser homem e do que é ser mulher. A violência conjugal é, portanto, uma tecnologia de gênero e uma violência de gênero.

\section{Considerações finais}

A violência conjugal é um tipo de violência de gênero. Isso implica dizer que as características que hoje a compõem e contornam não podem ser consideradas naturais e 
imutáveis. O presente artigo aponta que as experiências dos casais violentos constroem posições relacionais e subjetivas que perpassam representações tradicionais de gênero. As posições citadas influenciam para que as conjugalidades estabeleçam e rearranjem relações com hierarquia rígida. As relações de poder regidas por tais representações, em muitos casos, organizam e facilitam a experiência de novas violências.

A violência conjugal referendada como tecnologia de gênero é possível em um contexto histórico e social. Devem ser percebíveis como mutáveis as percepções de corpo, gênero e a própria sexualidade, além das possibilidades de posições subjetivas que se dão em contexto de violência conjugal. Assim, aquilo que pesquisas e percepções indiquem sobre a violência conjugal não vale para todas as relações, nem todos os tipos de experiência e nem todos os tipos de conjugalidade.

A violência conjugal apresenta elementos comuns a uma grande parte dos casais. Alguns desses elementos - como um sentido permeado por representações tradicionais de gênero e uma relação em que as percepções das diferenças sexuais culminam em desigualdades - foram apresentados para uma aproximação da violência conjugal a alguns elementos das tecnologias de gênero. Isso se deu para tentar compreender como a violência conjugal interpela posições aos sujeitos que constroem e reificam representações tradicionais de gênero como produto e processo das representações e auto-representações.

O texto aponta que não se pode indissociar várias das práticas violentas e suas relações com as construções das representações de gênero. Ao mesmo tempo, algumas das funções da violência se relacionam diretamente às representações de gênero, tornando aquela uma tecnologia de gênero. 


\section{ARTIGO 2 \\ ROTEIROS SEXUAIS E RITUAIS CONJUGAIS: CONSTRUÇÕES DA \\ VIOLÊNCIA SEXUAL NA CONJUGALIDADE}

Resumo: A experiência sexual conjugal é percebida como espontânea, íntima e privada ao casal. Ela é influenciada, no entanto, por construções a partir dos cenários culturais, interpessoais, intrapsíquicos e históricos que roteirizam e ritualizam a conduta sexual. A violência sexual do casal, inclusive o estupro, é pensada a partir de seus contextos atitudinais, discursivos e dinâmicos, ou seja, a violência está inserida em contexto cultural e na dinâmica relacional, impactando outras dimensões da conjugalidade. A violência não é disruptiva, não interrompe a conjugalidade. Pelo contrário, a violência sexual conjugal conta com elementos da dinâmica relacional de modo que suas práticas e significações favorecem a situação de violência conjugal.

Abstract: Sexual experience is perceived as spontaneous, intimate and a private experience within the couple. It is also influenced, however, by constructions from the cultural, interpersonal, intrapsychic and historical dimensions that affect the script and ritualize the sexual conduct. The sexual violence within the couple, including rape, is seen here from its attitudinal, discursive and dynamic contexts. Violence is not disruptive and does not interrupt conjugality. On the contrary, sexual violence includes elements of the relational dynamics so that its practices and meanings support intimate partner violence. 


\section{Introdução}

A violência conjugal é um fenômeno complexo, dinâmico e multideterminado. A compreensão de tal experiência deve passar por uma contextualização pessoal, relacional e sociocultural. Comportamentos idênticos e dinâmicas relacionais similares podem ter significados e interpretações díspares em culturas diferentes, para conjugalidades diferentes e mesmo para cada um dos membros do casal (Cordeiro, 2008; Diniz, 2011; Gagnon, 2006; Simon e Gagnon, 2005). A violência precisa ser pensada a partir de seu contexto pessoal, relacional e sociocultural para que seus diferentes sentidos possam ser problematizados e compreendidos.

Este artigo pretende problematizar a violência conjugal e seus elementos como inseridos em uma dinâmica relacional e em um contexto sociocultural. A violência é muitas vezes percebida ou referendada como elemento disruptivo da relação, ou seja, ela é retratada como ocorrendo pontualmente e isoladamente, como se fosse algo fora do contexto relacional. Nosso entendimento é que a violência acontece em um contexto atitudinal e discursivo, ou seja, os casais em situação de violência conjugal vivenciam a violência como parte de sua história e de sua dinâmica interacional. As cenas, as práticas e as dinâmicas violentas passam a fazer parte da biografia relacional deles.

Nesse contexto, apresentaremos, neste artigo, elementos teóricos para pensar a violência sexual como um processo atitudinal e discursivo. As práticas sexuais são referendadas na conjugalidade como íntimas e privadas, mas são influenciadas por elementos socioculturais - como as representações de gênero. A conduta sexual como uma prática social será levada em consideração para a análise da vivência dos casais a partir dos seus roteiros sexuais. Estes podem ser compreendidos como a interiorização dos modelos de funcionamento das práticas sexuais, a partir das construções sociais e dos aparatos culturais (Bozon, 2004; Gagnon, 2006; Gagnon \& Simon, 1984, 1986; Galli, 2013; Junqueira, 2014) 
As noções de violência sexual na conjugalidade, mais especificamente o estupro conjugal, também serão problematizadas. A perspectiva dos roteiros sexuais será a base através da qual serão pensadas as categorias da violência sexual como narrativas inseridas na dinâmica dos casais em situação de violência doméstica. As práticas sexuais violentas presentes na conjugalidade precisam ser dimensionadas a partir do contexto sociocultural e relacional, precisando ser consideradas a partir de seus contextos narrativos.

\section{Violência conjugal: estruturas narrativas e dinâmicas dos casais}

A violência que se dá entre os cônjuges tem características específicas. É relevante iniciar problematizando o conceito que perpassará o presente trabalho. Algumas nomenclaturas podem ser encontradas na literatura para fazer referência à presença de violência. Muitas vezes o termo utilizado é violência doméstica, violência contra o parceiro íntimo, violência contra a mulher e violência conjugal (Deeke, Oliveira \& Coelho, 2009; Guimarães, 2009; Narvaz \& Kohler, 2006; Pondaag, 2009; Rosa \& Falcke, 2014, Santos \& Izumino, 2005; Schraiber et al., 2007;).

A violência doméstica é um conceito que se revela abrangente e que poderia contemplar formas de violência além daquelas que ocorrem no contexto conjugal (Deeke et al., 2009). A violência intergeracional, ou seja, de pais contra filhos, filhos contra pais e a violência fraternal (irmão contra irmão) também poderiam, entre outras relações violentas, serem categorizadas como violência doméstica, pois elas ocorrem na intimidade da casa, ou seja, estão circunscritas à interação familiar.

A violência conjugal é um tipo de violência doméstica, que se configura geralmente na relação íntima e particular e se manisfesta, na maioria das vezes, nos espaços de socialização privados do casal. Essa pode ser considerada uma das especificidades da violência conjugal, ou seja, ela permeia o privado na distinção entre 
público e privado, mesmo que algumas vezes possa haver algum tipo de porosidade que produza vazamentos para o público.

A violência contra o parceiro íntimo é o modo como tem sido chamada a violência conjugal pela literatura internacional, acompanhada por alguma literatura nacional (Lindner, Coelho, Bolsoni, Rojas \& Boing, 2015; Schraiber et al., 2007; Vieira, Perdona \& Santos, 2011). A relação de intimidade é onde se manifestam formas de violência que contam uma história da relação e da dinâmica do casal. O parceiro íntimo é aquele que, muitas vezes, atende às necessidades de cada um no que diz respeito às dimensões relacionais, tais como a oferta de afeto e apoio mútuos, o exercício da sexualidade, o compartilhamento da vida doméstica, a sociedade financeira, a confidencialidade etc. O agressor ou a vítima - em situação de violência perpetrada por parceiro íntimo - compartilha várias outras dimensões relacionais e mesmo afetivas que qualificam e dão sentidos à história do casal.

O uso da locução violência contra a mulher reflete um modo como a violência conjugal foi redimensionada. Essa terminologia é consequência também dos avanços que os estudos feministas sobre a violência doméstica proporcionaram (Saffiotti, 2001, 2007; Santos \& Izumino, 2005). Há o reconhecimento abrangente na literatura de que as representações de homens e mulheres se dão em contextos que possibilitam e/ou facilitam a desigualdade. As relações hierárquicas entre os membros do casal evidenciam que as violências mais graves e cruéis, presentes nas relações conjugais, vitimam mais as mulheres (Diniz, 2011, 2013; Pondaag, 2009; Soares, 1999). O enfoque que considere a diferença entre homens e mulheres na situação de violência conjugal é necessário para compreender como se estruturam as experiências de vítimas e autores de violência.

A opção pelo uso do termo violência conjugal foi feita aqui para sobrelevar o contexto relacional e dinâmico em que a violência se dá (Guimarães, 2009; Narvaz \& 
Kohler, 2006; Pondaag, 2009; Rosa \& Falcke, 2014). Essa escolha não pretende ignorar o fato de que se trata de uma violência típica de lugares privados, como a casa, de que se dá em relações específicas de intimidade e afeto e de que sua face mais comum e cruel é apresentada às mulheres. A violência conjugal, no contexto deste artigo, é compreendida como "uma modalidade específica de violência de gênero, portanto, doméstica, que ocorre entre os cônjuges em uma relação de intimidade" (Cunha, 2008, p. 168).

A violência conjugal é um tipo de violência que por ocorrer em um contexto relacional, entra na história do casal, como uma parte de sua biografia. Dependendo do momento em que adentram a história do casal, as situações de violência vão ter significados diferentes. O fato é que suas representações podem ser negociadas constantemente. Os membros do casal, ao relatarem esse tipo de violência, mostram que eles têm vieses discursivos específicos, que estão relacionados ao que aconteceu com eles próprios, na condição de pessoas que se relacionam e trocam experiências em múltiplas dimensões. Eles se posicionam subjetivamente, como homem, mulher, vítima, autor, culpado, ressentido etc. As cenas violentas e suas reedições ganham motivações, explicações, justificativas etc. (Moura, Lefevre \& Moura, 2012; Álvarez et al., 2007; Cordeiro, 2008).

A partir de suas posições relacionais e de aspectos intrapsíquicos, suas dinâmicas e aspectos interpessoais e suas representações e aspectos culturais, a violência é apresentada pelos casais por meio de estruturas narrativas diversas. Os discursos apresentados pelos membros dos casais em situação de violência conjugal podem ir na direção de culpabilizar a vítima e de desresponsabilizar o autor "fora de si" (Diniz, 2011, 2013; Lamoglia \& Minayo, 2009; Walker, 2009;).

A dinâmica conjugal é permeada por essas estruturas narrativas. O ressentimento pode funcionar como um adendo à nova dinâmica do casal (Brandão, 2006). A presença 
de violências graves estabelece condições de credibilidade às novas ameaças e favorece formas de controle regulares, geralmente, sobre as mulheres (Dutton \& Goodman, 2005; Schraiber, Oliveira, Portella \& Menicucci., 2009). Serão apresentados aspectos descritos na literatura que permeiam a violência conjugal e a estruturam por meio de suas perspectivas narrativas.

\section{O redimensionamento da violência conjugal}

Compreender a vivência entre casais em situação de violência conjugal implica conhecer e nomear um conjunto de práticas que dá sustentação a essa experiência. Pondaag (2009) aponta a violência como um processo atravessado pela anonímia, que envolve a não percepção das agressões vivenciadas como violência. A experiência passa a ser marcada por silêncio, segredo e pela não nomeação da violência. Esta autora aponta o sofrimento como categoria que permite às pessoas agredidas alcançarem a dimensão afetiva da violência conjugal.

Pondaag (2009) constatou em sua pesquisa que as pessoas tendiam a não nomear a violência não só por uma questão vocabular. A não nomeação da violência redimensionava semanticamente a mesma. Variadas estratégias de redimensionamento dos sentidos, tais como justificativas, minimização, negligência e mesmo negação aparecem na literatura como uma dimensão importante da vivência de violência - todas elas contribuem de forma significativa para sua manutenção (Ravazzola, 2005; Diniz \& Pondaag, 2004, 2006; Álvarez et al. 2007, Pondaag, 2009; Diniz, 2011; Diniz, 2013).

As posições subjetivas e aspectos intrapsíquicos podem indicar aquilo que Ravazzola (2005) aponta como anestesias. Elas revelam que quando uma situação fere, a pessoa tende quase automaticamente a defender-se e a afastar-se da situação. Em determinados momentos, a violência conjugal é uma dessas situações. Muitas vezes 
aqueles que estão envolvidos na dinâmica conjugal marcada pela violência não conseguem se afastar ou se defender.

Desconexões afetivas, dificuldades de nomear as experiências violentas, apagamentos compreensivos revelam o mal-estar que marca a relação. Encontramos anestesias também nos autores da violência, que tentam, por exemplo, apagar a própria culpa. Os autores frequentemente agem como se o sofrimento pudesse não ser sentido pela vítima ou como se ele fosse banal ou extremamente passageiro. Acreditam, por exemplo, que a dor gerada pelo ato violento possa ser negociada em troca de um pedido de perdão rápido e pouco elaborado (Diniz, 2011; Ravazzola, 2005).

A dinâmica de um casal em situação de violência conjugal envolve geralmente um funcionamento com justificativas para as cenas violentas ou para a presença do estilo violento na conjugalidade (Hirigoyen, 2006; Diniz \& Pondaag, 2004, 2006; Pondaag, 2009). As justificativas podem ter as mais diversas funções na dinâmica do casal. Uma delas é a dificuldade de agir frente à violência, de colocar limite, o que dificulta a mudança da condição violenta ou o rompimento da relação. As justificativas podem ter como foco a culpabilização da vítima e consequente desresponsabilização do autor (Narvaz \& Koller, 2006; Corsi, 2006; Hirigoyen, 2006; Rosa, Boing, Buchele. Oliveira \& Coelho, 2008).

Esse processo tem uma dimensão perversa - confunde a pessoa e dificulta sua compreensão acerca do que realmente aconteceu. Angelim (2009), tratando da ambiguidade das justificativas e interpretações para as agressões, propõe:

O episódio violento pode ser interpretado como demonstração de afeto e apreço motivada pelo ciúme. Visto dessa maneira, o gesto violento é uma expressão intensa de amor. A mulher vítima de violência pode se colocar, então, em uma posição compreensiva deixando de lado a dor das agressões para se aproximar do sofrimento causado pelo ciúme vivido por seu marido/companheiro. (p. 59) 
As justificativas que responsabilizam as mulheres e minimizam o descontrole masculino favorecem contextos relacionais entre os casais que enviesam o processo de negociação do significado da violência e favorecem para que a relação continue como tal. Essas mesmas justificativas funcionam como fator de risco para novas cenas violentas. O que mobilizou a violência deixa de ser negociado quando o significado da violência é alienado. Além disso, o silêncio é, muitas vezes, imposto às mulheres por causa das repercussões sociais que a violência poderia ter, ou seja, ao invés de ter seu significado negociado, muitas vezes a violência é retratada como segredo e não dito.

As representações sociais e os aspectos culturais relacionados ao ser homem, ser mulher e aos papéis de cada um permeiam a conjugalidade violenta e podem contribuir para reforçar essas estratégias de silêncio, minimização, justificativas e não nomeações da violência. A distinção entre o público e o privado se dá de forma que o último favorece um sentido de controle da informação, liberdade de não ser observado, liberdade da interferência ou intrusão externas (Okin, 2008).

A violência conjugal também tem suas representações associadas ao espaço doméstico, íntimo, privado (Saffioti, 2001). Desse modo, um mito ainda comum sobre a violência doméstica - facilitado pelos aspectos culturais que circunscrevem as práticas do casal como privadas - é o de que não se interfere nas vivências domésticas, mesmo que elas sejam um problema social (Diniz, 2011; Guimarães, 2009). Dentre os resultados de suas pesquisas sobre os sentidos da conjugalidade violenta, Pondaag (2009, p. 168) aponta que “a conjugalidade é significada pelos homens, independente deles serem os 'autores do fato', como uma experiência privada, em relação à qual não cabem intervenções externas".

Apresentamos aqui aspectos que influenciam um tipo de estrutura narrativa que envolve os membros de um casal em situação de violência conjugal, ou seja, as tendências à minimização, justificação, não nomeação e segredo. Esses processos se dão 
em contextos influenciados pelos aspectos intrapsíquicos - como no exemplo dado das anestesias (Ravazzola, 2005) - nos aspectos interpessoais e dinâmicos do casal - como no exemplo dado das justificativas - e nos aspectos socioculturais - como no exemplo dado acerca da noção de público e privado.

Condicionantes narrativos específicos perpassam a biografia do casal em situação de violência conjugal. Os membros do casal ressignificam a violência vivida a partir de certos elementos que a tornem inteligível para eles e possibilitem um compartilhamento na conjugalidade. Mesmo quando a violência é empurrada para debaixo do tapete, como nos indicam alguns aspectos atitudinais e discursivos apontados até aqui, ela adquire contornos compartilhados pelo casal.

\section{O ciclo da violência: uma dinâmica conjugal}

Outra forma de aproximação da violência conjugal que evidencia estruturações atitudinais e discursivas para as interações é o ciclo da violência, proposto por Lenore Walker (2009). O ciclo da violência possui três estágios compreendidos a partir das vivências de casais em situação de violência conjugal: 1) construção da tensão, 2) tensão máxima e 3) lua de mel (Walker, 2009). O ciclo a ser descrito não compreende todas as vivências de violência conjugal e nem se apresenta igual em todas elas, ou seja, em um mesmo casal podem ocorrer mudanças em termos de intensidade, formas de violência e tempo de cada estágio em cada ciclo.

O primeiro estágio ou fase do ciclo da violência é constituído pelo aumento da tensão, ou seja, acontecem as formas de violência menos intensas. A intensidade vai aumentando gradual e insidiosamente. Guimarães (2009, p. 81) afirma que, nesse estágio, "o casal tende a considerar os fatos como se estivessem sob controle, e tece explicações racionalizadas para aceitá-los em seu cotidiano”. Em algum momento, essas 
explicações têm seus significados alterados e deixam de corresponder ao que está acontecendo entre o casal.

A culpabilização da mulher pelos incidentes vai gerando nela tentativas de agradar e reduzir os comportamentos hostis do homem. Se ela tem sucesso, mesmo que por pouco tempo, isso reforça suas crenças pouco realistas de que ela é capaz de controlá-lo (Walker, 2009). Assim, à medida que o parceiro tende a ficar mais opressivo, a mulher tende a ficar mais vigilante até a tensão ficar inviável de ser mediada.

O segundo estágio, da tensão máxima, é quando ocorre a eclosão da violência. Corresponde ao reconhecimento do descontrole e da intensidade da violência em seu potencial máximo relativo ao casal em questão. Como explica Walker (as cited in Guimarães, 2009, p. 81) “o episódio violento leva a uma reconfiguração da dinâmica relacional do casal, podendo acontecer uma separação, intervenção de terceiros ou a manutenção da relação violenta em outro estágio do ciclo.”

No terceiro estágio, a lua de mel, há uma tentativa de reaproximação com reestruturação da conjugalidade. O agressor pode expressar arrependimento, tentar cuidar da vítima, ser gentil, enchê-la de presentes e promessas, podendo realmente acreditar que não será violento de novo (Walker, 2009). A sedução e a reaproximação afetuosa caracterizam esse estágio, em que, segundo Walker (2009, p. 94-95) tem-se a seguinte repercussão:

\footnotetext{
A mulher quer acreditar no agressor e, no início do relacionamento, pelo menos, pode renovar a sua esperança na capacidade dele de mudar. $\mathrm{O}$ terceiro estágio fornece o reforço positivo para a manutenção da mulher na relação. Muitas das ações que ele fez quando ela se apaixonou por ele durante o período de namoro ocorrem novamente aqui. ${ }^{4}$
}

\footnotetext{
${ }^{4}$ Tradução livre do autor principal do artigo.
} 
A tendência do ciclo é se repetir indo da lua de mel para o primeiro estágio novamente. A intensidade e frequência das agressões vão aumentando ao longo dos ciclos. O encurtamento do primeiro e do terceiro estágio também é outra tendência apresentada em grande parte dos casais em situação de violência conjugal (Walker, 2009).

Um dos aspectos intrapsíquicos que perpassam o ciclo da violência é a idealização. Na terceira fase, apontada como responsável pela manutenção do relacionamento, mantem-se a ilusão de que o homem pode ser diferente. Esse processo contribui para sustentar os ideais da mulher, que costumam ser reeditados nas promessas do cônjuge. O fato é que, movido pela culpa e necessidade de reparação, ele procura se comportar de forma similar à que eles experienciaram nos primeiros momentos da relação, quando estavam apaixonados e os desejos pareciam ligados a ideais de manutenção da relação que seriam concretizados.

Os ideais de ambos possibilitam que uma estrutura narrativa como o ciclo da violência seja recontada de forma cíclica, da terceira para a primeira etapa. As mulheres, em sua maioria, têm - pelo menos nas primeiras transições entre os ciclos - dois conjuntos de ideais acerca de si e do outro. Um deles é o de que ela, pelo seu comportamento e pelas suas intenções, é capaz de transformar o outro.

Esse ideal permeia a fase do aumento da tensão, contexto em que ela tenta fazer as coisas do jeito que o parceiro gostaria para que o mesmo não perca o controle. Isso pode estar relacionado com a prescrição social de que a mulher exerça o papel de compreensiva, de cuidadora do outro, ou seja, que de modo ideal ela seja capaz de resgatar o homem das suas dificuldades, sejam emocionais, vícios em álcool e/ou outras drogas, empregatícias etc.

Outro elemento que favorece a idealização é o mito do amor romântico - que tudo sofre e tudo perdoa. As imagens idealizadas do parceiro e da mulher continuam 
mediando a relação por algum tempo. Ela acredita que ele só não alcança esse conjunto de ideais por causa de algo que o desresponsabiliza. Ela própria, o trabalho, os filhos, o álcool e/ou outras drogas, entre outros, são alguns dos motivos para que ele não seja o parceiro ideal em um relacionamento ideal (Àlvarez et al. 2007; Diniz \& Pondaag, 2004, 2006; Pondaag, 2009; Ravazzola, 2005; Walker, 2009).

As promessas do parceiro, durante a lua de mel, remontam a esse lugar do “ideal”. Muitas vezes, elas são extremamente similares a esses ideais, mesmo que eles nunca tenham vivido o relacionamento como ideal ou que ele nunca tenha se encaixado na posição relacional de parceiro ideal. $\mathrm{O}$ fato é que os ideais intrapsíquicos permeados pelos desejos funcionam de modo que a lua de mel tenha efetividade como mantenedora do relacionamento, sem que ocorra a devida compreensão da violência e reconfiguração da percepção da relação como possuindo uma dimensão violenta.

A experiência com as cenas violentas graves é abafada pela fé em um relacionamento idealizado, amoroso e que possa trazer mais benefícios do que dor. A narrativa relacional que permeia a conjugalidade violenta é imbricada em ideais que transformam posições subjetivas, como a de mulher vítima em mulher que deve lutar pelo bem-estar do algoz e da família.

Os aspectos interpessoais também conduzem a narrativa das situações de violência entre os cônjuges. O próprio ciclo da violência pode ser entendido como contando a história da dinâmica do casal. Na primeira fase, o homem tenta controlar a relação contando com aquilo que a mulher precisa fazer para ele não ter o humor ainda mais alterado. A mulher tenta controlar as alterações da tensão instaurada, tentando atender as demandas do homem e fazer o possível para não desagradá-lo.

Em situações extremas, ela pode estimular o aumento da tensão para controlar as consequências, por exemplo, em uma situação onde há menos risco (Walker, 2009). Na segunda fase, o controle ilusório da fase anterior é alterado pelo descontrole da parte de 
ambos, em que os humores do homem podem levá-lo a incidências graves de violência e a mulher tem a percepção de que não consegue controlar a tensão. Na terceira fase, quando ele pendula entre o relaxamento e a culpa, ela, na tendência cíclica, passa a acreditar que terá controle o suficiente para cuidar de si e do agressor, cujas promessas envolvem o bem-estar e a não repetição da violência.

Um aspecto sociocultural que influencia a estrutura narrativa do ciclo da violência é a representação da mulher culpabilizada por experiências em que é vítima. Muitos dos que estão fora do contexto narrativo da dinâmica do casal têm a idéia de que essa é uma conjugalidade que vive em situação conflituosa grave, mas a mulher não se separa porque não quer porque ela gosta de apanhar (Saffioti, 1999, 2003; Brandão, 2006). A última perspectiva gera dificuldades para ouvir o sofrimento da mulher, antes e após a fase aguda da violência.

Nesse contexto, parece difícil entender a perspectiva da mulher durante a fase da lua de mel, na qual ela "acredita" que o marido vai se transformar e que eles viverão um ótimo relacionamento dali para a frente, momentos depois de cenas graves de violência. A ininteligibilidade do que eles experienciam indica uma perspectiva discursiva da violência que é singular ao casal. Muitas vezes a falta de inteligibilidade para terceiros é fator de risco, por tornar o discurso da mulher - entre o sofrimento e a crença em um ótimo relacionamento - pouco compreensível para sua rede social.

Os aparatos de justiça, segurança, proteção e redes sociais, incluindo pessoas mais íntimas, percebem o discurso como inconstante e descolado da realidade. Essa condução biográfica do casal é algo incorporado socioculturalmente como estranho, mas que tem um sentido dentro da história do casal. A narrativa que envolve o ciclo da violência coloca os agentes externos em posição que envolve dificuldade de entendimento daquela situação violenta. Então, eles passam a usar como anteparo para o estranhamento as representações que culpabilizam a vítima, que já estão disponíveis 
culturalmente, tais como a de que a mulher gosta de apanhar, de que ela apanhou porque fez algo de errado ou de que se ela apanha e continua na relação, é tão sem vergonha quanto ele que bate.

Os estágios do ciclo da violência - o aumento da tensão, a tensão máxima e a lua de mel - têm características que indicam estruturas narrativas das experiências conjugais na situação de violência. Entre os aspectos intrapsíquicos, a idealização e os ideais de relacionamento permeiam posições subjetivas também ideais para o homem e para a mulher. Entre os aspectos interpessoais, a mulher tenta controlar a tensão que se pauta pelos humores do homem e por aquilo que ele indica que o agrada ou desagrada. Entre os aspectos socioculturais, a representação da mulher como responsável pela manutenção da conjugalidade e da família, pode fazer com ela se sinta culpabilizada pelas experiências em que é vítima. Esse processo regula a ininteligibilidade de quem está fora da relação, dos elementos atitudinais e discursivos que pautam a dinâmica da conjugalidade.

As construções narrativas da violência conjugal - envolvem dimensões intrapsíquicas, interpessoais e socioculturais - compõem os sentidos atribuídos às experiências que o casal vive. A violência é uma dimensão da conjugalidade, como a organização da vida doméstica, a afetividade, o trabalho, a sexualidade, entre outras.

Essas dimensões que permeiam as vivências dos casais têm intersecções e interdependências entre si. As agressões não são eventos pontuais que descontinuam a conjugalidade. A estrutura narrativa que dá sentido e organiza a biografia do casal em situação de violência influencia também outras dimensões. A dimensão da sexualidade constitui o foco de nosso interesse. 


\section{Os roteiros sexuais e rituais conjugais: a construção da conduta sexual}

A sexualidade é uma dimensão importante da conjugalidade. Ela é representada como natural e espontânea, como algo para a qual os corpos já estão adaptados e preparados. A percepção normalizada das práticas sexuais é de que elas são naturalmente e evidentemente prazerosas. A adaptação dos corpos ao jogo sexual é vivenciada como se seus movimentos ou encaixes fossem preordenados e funcionassem de forma mais ou menos parecida para todos.

Os contextos culturais são vistos como provocando pequenas variações nessas representações e nas práticas sexuais. É como se a naturalidade da sexualidade fosse preservada ao longo dos tempos. A conduta sexual, nessa percepção, parece ser aquilo que nos é comum e, ao mesmo tempo, aquilo que nem precisamos partilhar ou aprender. O exercício da sexualidade é delimitado como essencialmente privado. Os casais têm a percepção de que as suas práticas sexuais são realizadas a partir de suas vontades, desejos e necessidades mais íntimas (Gagnon, 2006; Heilborn, 2006; Simon \& Gagnon, 2005).

A verdade é que o corpo e as diferenças sexuais foram constituídas e instituídas socialmente. As próprias práticas sexuais são construídas na cultura. A fala de Heilborn (2006, p. 43) sobre a dimensão sexual deixa claro essa construção:

essa dimensão humana não é natural, nem universal em sua forma de expressão, nem inata e, de um ponto de vista sociológico, não pode ser interpretada como pulsão psíquica ou função biológica. [...] a expressão da sexualidade se dá em um contexto social muito preciso, o que orienta a experiência e a expressão do desejo, das emoções, das condutas e práticas corporais.

“Orientar" pode significar tanto dar a conhecer, como regular, normatizar. Assim, o contexto social favorece que se possa apreender perceptivamente e afetivamente a experiência, mas também indica condições específicas e limitadas para que essa experiência se dê. Essas condições específicas são apontadas por Heilborn 
(2006, p.45): “indivíduos são socializados para a entrada na vida sexual por meio da cultura, que orienta roteiros e comportamentos, considerados aceitáveis para cada grupo social." A esses roteiros, comportamentos e apreensões do sexual correspondem diferentes compreensões e significações que se manifestam de formas distintas nas práticas conjugais.

As práticas sexuais - assim como outras atividades, como jantar, jogar amarelinha, fazer compras ou dançar - não dispensam um corpo estruturado. As mais variadas experiências sociais conformam os corpos para que eles executem tais atividades de formas específicas, mesmo que o sujeito tenha a sensação de estar sendo extremamente espontâneo. Conscientemente ou não, constrói-se um arcabouço psíquico, interpessoal e cultural, que organiza a vida social encenada pelo corpo subjetificado. $\mathrm{O}$ percurso que o sujeito atravessou e o modo como esse processo influencia os roteiros para a conduta sexual é o que está em questão, mesmo que ele possa escolher e agir com alguma espontaneidade e conforme o que pensa e sente.

As representações que criam o sistema sexo/gênero são algumas dessas estruturações da experiência social que influenciam as práticas sexuais. Judith Butler (2002, 2013) radicaliza a construtividade corporal, inscrevendo gênero e sexo como indiferenciados em termos de apreensão objetiva, já que ambos são constituídos e instituídos no contexto social e discursivo dos sujeitos. Assim, a caracterização de gênero como um corpo prévio interpretado posteriormente pelo social é inócua, pois segundo Butler (2013, p. 25) “o próprio construto chamado 'sexo' seja tão culturalmente construído quanto o gênero; a rigor, talvez o sexo sempre tenha sido o gênero, de tal forma que a distinção entre sexo e gênero revela-se absolutamente nenhuma”.

O gênero não é simplesmente a contraparte social na interpretação de corpos que apresentam diferenças sexuais, tais como homens e mulheres que têm respectivamente 
pênis e vaginas. Scott (2011, p. 95), apresenta a seguinte perspectiva acerca dessa discussão:

Algumas críticas (Judith Butler, Donna Haraway) indicam que a distinção era falsa, porque se o gênero poderia ser construído culturalmente, o mesmo poderia ser feito com significados biológicos do sexo. Na verdade, foi o gênero que atribuiu à biologia sua significação supostamente inata. ${ }^{5}$

O sexo ou a diferença sexual não podem, para Butler (2002, 2013), figurar em um domínio prévio ao discursivo. A materialidade do corpo foi colocada como domínio então do social. O corpo não é só interpretado pelo discurso, ele é construído no contexto da produção social.

O homem e a mulher, por exemplo, são representados como tendo órgãos eróticos típicos para as relações sexuais mais naturalizadas, o pênis e a vagina respectivamente. O corpo masculino ou masculinizado é localizado como o corpo que penetra - em alguns casos o que agride - e o corpo feminino ou feminizado é localizado como o corpo que é penetrado (Damatta, 2010; Souza, 2009). A experiência corporal a partir da metáfora da penetração é tão balizada, inclusive na literatura técnica, que os corpos dificilmente têm outro contorno ou localização.

Uma alternativa, apenas a título de reflexão, de uma construção metafórica sobre a sexualidade poderia ser a inundação do feminino sobre o masculino, o inundado. A percepção dos corpos atravessada por essa imagem é pouco inteligível. Não é só uma questão de interpretação discursiva sobre o corpo, é a própria construção da matéria. $\mathrm{O}$ pênis - a espada - é contornado compreensivamente, como atributo material, tendo a penetração como uma de suas características e funções. Da mesma forma, a vagina - a bainha - é compreendida com atributos materiais de penetrabilidade.

\footnotetext{
${ }^{5}$ Tradução livre realizada pelo autor principal do artigo.
} 
Essas características dos corpos são fundantes das relações que se dão não só entre os corpos durante as práticas sexuais, mas também nas comunicações midiáticas, aparatos de saúde, decisões judiciais, educação sexual, entre outros. Vale apontar um exemplo: em decorrência do crescimento da Aids nos anos 80 e 90, as políticas de saúde modificaram o tratamento discursivo do sexo oral, um fator de risco, apregoando-o como penetrativo.

Essa mudança discursiva fez com que depois disso, vários artigos da área da saúde e que tratam dos riscos do exercício da sexualidade associados a doenças sexualmente transmissíveis qualifiquem a penetração oral (Chambers, 2007; Stone, Hatherall, Ingham \& McEachran., 2006). A expansão da discussão sobre a violência sexual também expandiu a noção de penetração oral para as interações violentas que se dão por meio de contato sexual entre órgão genital e boca (Silva \& Muro, 2014; Vertamatti, Abreu, Drezett, Valenti \& Barbosa, 2013).

A percepção da boca como local de penetração a recria como órgão sexual, já que com o uso dela, nas práticas sexuais, vivencia-se o risco de doenças sexualmente transmissíveis e a violência sexual plena. No entanto - apesar de a penetração oral agora ser percebida de forma mais inteligível pela cultura, especialmente no campo da saúde a expressão sexual que compõe a interação entre o pênis ou a vagina e a boca geralmente são interpretados na cultura em oposição à penetração, seja ela vaginal ou anal.

Esse exemplo denota que a boca é ocasionalmente transformada em sua matéria, ou seja, como adendo das funções e características que envolvem penetrabilidade. Essa transformação ocorreu a partir de um dado momento histórico, de um contexto cultural e das mudanças nas práticas de significação correspondentes. Da mesma forma, o modo como os corpos são vistos e práticas sexuais se dão está pautado em um contexto 
cultural e discursivo que os/as interpretam, mas, além disso fundamentam-nos, estruturam-nos e tornam-nos inteligíveis.

O gênero precisa ser analisável de acordo com a sua inteligibilidade. Butler (2013) argumenta que para que o gênero seja compreensível, o sujeito deve manter performances coerentes e contínuas entre sexo, gênero e desejo. Há a tentativa de, na apreensão discursiva da sexualidade, compreender como estáveis e indissociados entre si os elementos: sexo, gênero e desejo. Assim, é naturalizado que se alguém tem um sexo específico, identifique-se com um gênero específico e tenha percepções desejantes específicas associadas entre si. É naturalizado e normatizado, por exemplo, que exista um macho na natureza, que esse se identifique como homem e que sinta desejos por fêmeas identificadas como mulheres.

A relação entre sexo, gênero e desejo não é coerente e contínua como a inteligibilidade ou normatividade aponta:

A questão acerca do que estará excluído da norma estabelece um paradoxo, pois se a norma confere inteligibilidade ao campo social e normatiza esse campo para nós, então estar fora da norma é continuar, em certo sentido, a ser definido em relação a ela. Não ser totalmente masculino ou não ser totalmente feminina é continuar sendo entendido exclusivamente em termos de uma relação a "totalmente masculino" e "totalmente feminina". (Butler, 2014, p. 253)

As relações entre sexo, gênero e desejo podem ser dissonantes daquilo que as normatiza e hierarquiza. A dissonância ou a consonância em relação ao socialmente prescrito não são estáveis. As subjetividades envolvidas nas relações entre sexo, gênero e desejo não têm, como as expectativas poderiam demandar, uma natureza essencial que torne as interações entre esses três elementos perenes. Essa perenidade ou estabilidade na relação entre sexo, gênero e desejo não é mantida nem social, nem historica e culturalmente, e muito menos corporalmente. 
$\mathrm{Na}$ relação que o sistema sexo/gênero opera nas interações sexuais dos casais, o homem é representado como aquele que busca a interação sexual e a mulher como aquela que cede à busca sexual. Essa diferença possibilita interpretações das experiências reais em contextos específicos. As ações são valoradas a partir das normas de procedimentos relacionais e corporais.

Assim, o homem que faz sexo somente quando é demandado pode ser interpretado como alguém que não deseja a mulher. Da mesma maneira, a mulher que sempre demanda pode ser interpretada como muito intrusiva, fogosa ou sem pudor. O homem que requer a relação sexual e a mulher que cede a essa solicitação são interpretados geralmente como agindo mais de acordo com as normas, valores e expectativas sociais (Zampieri, 2004). A diferença sexual, construída discursivamente, é percebida como naturalizada e conforma práticas relacionais e sexuais particulares, além das representações e interpretações das experiências e posições relacionais.

As práticas sexuais precisam ser compreendidas como práticas sociais, permeadas por corpos construídos e estruturados em sua materialidade. A análise das práticas sociais, como a relação sexual, pode ser feita ao se relacionar o contexto em que elas acontecem e os significados atribuídos pelos autores aos seus personagens em cena e às suas ações. Uma apropriação sensível das experiências sexuais demanda que sejam levadas em conta as expectativas, planejamentos, valores, crenças, experiências, interpretações de todos os atores envolvidos nas cenas sexuais.

Os roteiros sexuais - conceitos construídos por John Gagnon e William Simon (1984, 1986, 2005) com base em suas pesquisas sobre as fontes sociais da sexualidade serão referência para a análise da sexualidade violenta. Eles são entendidos como a interiorização de modos de funcionamento das práticas sexuais. Estes roteiros descrevem uma sexualidade possível, a organizam e a estruturam, como em um aprendizado técnico, a partir da impregnação dos múltiplos relatos pessoais, familiares, 
sociais e culturais. Eles funcionam como planos ou projetos antecipatórios e retrospectivos que avaliam o que acontece na prática sexual e conduzem as respectivas expectativas.

Gagnon (2006, p. 220) afirma que:

A sequência do que deve ser feito num ato sexual depende da existência prévia de um roteiro que defina o que deve ser feito com tal ou qual pessoa, em tal ou qual circunstância, em tal ou qual ocasião, e quais são os sentimentos e motivações apropriados a esse evento [...] Fornece orientação quanto ao que é ou não é uma situação sexual e contém os elementos que ligam a vida erótica à vida social em geral [...] Os roteiros não são uma mera propriedade cognitiva de atores isolados; devem existir como parte da estrutura social.

Os roteiros se apresentam, portanto, em três dimensões: cenários culturais, interpessoais e intrapsíquicos (Bozon, 2004; Gagnon, 2006; Gagnon \& Simon, 1984; 1986; Galli, 2013; Junqueira, 2014). A dimensão intrapsíquica dos roteiros sexuais é um conjunto complexo de significados superpostos. O material simbólico que erotiza é proveniente de meios de comunicação ou de experiências locais, e aponta para condensações e micropontos das vivências sensoriais, excitações, interpretações e cenários culturais (Bozon, 2004; Gagnon, 2006). Os roteiros intrapsíquicos criam a fantasia, a reorganização simbólica para que o ator acesse múltiplas camadas e dissonâncias dos desejos individuais que são conectados aos significados sociais da conduta sexual (Simon e Gagnon, 1984).

A dimensão intrapsíquica dos roteiros sexuais envolve dois passos, de acordo com Gagnon (2006, p. 221):

Existem os "fragmentos" e "emoções" mentais eróticos, que são a fonte dos sentimentos do erótico. Posteriormente, estes são codificados em roteiros cognitivos mais organizados, que constituem os guias das interações concretas com outras pessoas. Essa necessidade de uma roteirização interna ocorre durante todas as condutas sexuais que envolvem a coordenação da vida mental com o comportamento social. 
Há então uma estruturação que envolve o reconhecimento das situações sexuais, a diferenciação entre estas e as situações sociais não sexuais e os estados corporais concernentes (Bozon, 2004; Gagnon, 2006;). Os roteiros intrapsíquicos orientam as condutas sexuais presente e posteriores e interpretam a passada, na forma de projetos, como planos para ações (Bozon, 2004; Gagnon, 2006; Paiva, 2000).

Os roteiros interpessoais resolvem a falta de coesão entre os cenários, os ordenamentos abstratos e a situação concreta. O ator social deixa de ser mero personagem para conjuntamente escrever com sua participação e posição na cena, o seu papel. Assim, as expectativas se aliam às identidades em contextos e ações particulares e ritualizadas (Bozon, 2004; Gagnon, 2006; Parker, 2010; Simon \& Gagnon, 1984).

A pressuposição do outro coerente com as práticas é fundamental para ligar o contexto material e social à conduta sexual (Bozon, 2004; Gagnon, 2006; Galli, 2013; Paiva, 2000). Os níveis interpessoais de roteirização diminuem a incerteza quanto às práticas sexuais e aumentam a legitimidade de suas interpretações (Galli, 2013; Simon \& Gagnon, 1984).

Os cenários culturais que primeiro foram analisados por Simon e Gagnon (2005) foram as representações de sexo explícito, a pornografia. Apesar de serem limitadas em termos de práticas e roteiros, essas representações possuíam indicações evidentes do que era apropriado como motivador de excitação ou conduta sexual (Simon \& Gagnon, 2005; Gagnon, 2006). As questões que são colocadas frente aos cenários culturais vão além de normas, valores ou crenças e precisam ser retomadas como conformando elementos atitudinais que se integram das mais diversas formas e estruturações nas narrativas sexuais que compõem os roteiros sexuais (Gagnon, 2006). Os cenários culturais definem prescrições de ordem coletiva, que demandam práticas dos atores a 
partir do que é interditado, daquilo que pode ser feito durante as práticas sexuais, do que é exigido de cada um dos envolvidos (Bozon, 2004; Parker, 2010; Gagnon, 2006).

Os direcionamentos que são retomados como instruções estão em todas as instituições, como a família, a escola, as igrejas, entre outras. A construção do sistema sexo/gênero é uma dessas formas de encaminhamento no nível do cenário cultural para a operacionalização da conduta sexual. Assim, elementos corporais pressupõem um nível de roteirização, pois o sujeito que acessa o corpo em uma festa, por exemplo, empreende um sentido erótico, oferece uma estrutura narrativa a partir de uma imagem, cuja composição contempla elementos interpretativos como a idade, o estágio no ciclo de vida, a estruturação dos órgãos visíveis no corpo, as cores, as roupas, as expressões faciais, entre outros. A interpretação é a organização dos elementos em um roteiro plausível que conte com as expectativas também atitudinais do outro.

Os rituais familiares e conjugais - como compreendidos nas práticas da terapia sistêmica - compõem as análises das significações e práticas sexuais. Os rituais são atos simbólicos que contêm partes abertas - não definidas e/ou plásticas e partes fechadas definidas e/ou rígidas (Imber-Black, 2006a; Roberts, 2006). As partes dos rituais se mantêm ligadas por uma metáfora orientadora, a qual organiza também eventos prévios organizadores e eventos posteriores como partes significativas do ritual (Roberts, 2006).

As práticas e significações sexuais são, nessa perspectiva, rituais conjugais que mantêm e estruturam as relações dos casais. Roberts (2006, p. 45) afirma que "se o ritual é um meio de conectar a estrutura e o significado, pode-se pôr em jogo os dois aspectos da vida familiar." Assim, as sequências interacionais dos cônjuges - a preparação para o sexo, as práticas sexuais, as atividades que possibilitam o retorno à vida cotidiana - estão em jogo tanto quanto o que fazer sexo significa para cada um dos parceiros sexuais.

\footnotetext{
${ }^{6}$ Tradução livre do autor principal do texto.
} 
Os rituais podem ter como motivações estruturantes o status dos membros, o pertencimento familiar, social e cultural, as identidades de cada um, os modos de expressão ou de negociação de crenças, comemoração, reconciliação, entre outras dimensões (Crespo, 2011, 2012; Crespo et al, 2013; Imber-Black 2006a, 2006b; Roberts, 2006; Smit, 2011; Whiting, 2006). Os rituais têm a capacidade de vincular tempos, manter contradições e trabalhar com as mudanças das relações em ação (Roberts, 2006).

Os processos de manutenção e mudança se sustentam por meio dos rituais, em que as práticas sexuais, em muitas situações, conflitam com os significados atribuídos a elas. Carmona (2011), em pesquisa sobre as negociações no âmbito da sexualidade, constatou que todas as mulheres falaram de amor, afetividade e outros aspectos de cunho romântico quando lhes foi pedido para associar espontaneamente sobre a sexualidade. A mesma pesquisa apontou que a maioria das entrevistadas cede aos avanços sexuais do homem para evitar conflitos. A contradição entre as motivações que elas denotam e as que aparecem são sustentadas pela regulação dos rituais. Os rituais sustentam as contradições inerentes aos significados e às estruturas ou sequências práticas.

A conduta sexual pode ser interpretada como não violenta pelos membros do casal, mesmo contendo contradições rituais, como práticas sexuais humilhantes, muita insistência, consentimento por medo etc. A dimensão sexual pode, por outro lado, não abarcar essas contradições e o ritual ser percebido como evidentemente violento em muitos relacionamentos. O ritual se transforma e deixa de abarcar a contradição entre a idealização da sexualidade e a prática coercitiva, situando a expressão corporal como violência sexual. O ritual que contempla o estupro, por exemplo, abarcaria possivelmente outras contradições, que também merecem atenção. 


\section{A violência sexual conjugal}

A violência sexual conjugal é imersa em práticas e discursos relacionais e dinâmicos. A violência sexual, ao ser referenciada na Lei Maria da Penha - a Lei 11.340/2006 - é redimensionada como violação de direitos. Essa estruturação do conceito é importante, pois leva em conta os direitos sexuais e reprodutivos, que podem se transformar e alcançar diversas práticas protetivas e assistenciais. Violência no âmbito da sexualidade também é, por exemplo, forçar práticas abortivas, forçar o casamento, forçar a exposição a doenças sexualmente transmissíveis e a divulgação de imagens íntimas, entre outras. A violência sexual é tipificada na lei do seguinte modo:

A violência sexual, entendida como qualquer conduta que a constranja a presenciar, a manter ou a participar de relação sexual não desejada, mediante intimidação, ameaça, coação ou uso da força; que a induza a comercializar ou a utilizar, de qualquer modo, a sua sexualidade, que a impeça de usar qualquer método contraceptivo ou que a force ao matrimônio, à gravidez, ao aborto ou à prostituição, mediante coação, chantagem, suborno ou manipulação; ou que limite ou anule o exercício de seus direitos sexuais e reprodutivos. (Brasil, 2006, p. 14)

Feix (2011) aponta que a partir do surgimento de legislação internacional sobre a questão da violência sexual que foram provenientes de Conferências Mundiais que ocorreram no Cairo, em Copenhagen e Pequim), pode-se afirmar que os direitos sexuais e os direitos reprodutivos abrangem os seguintes conteúdos normativos, entre outros:

Direitos Sexuais: 1) O direito de explorar a própria sexualidade sem medo, vergonha, culpa, falsas crenças e outros impedimentos à livre expressão dos próprios desejos e orientação sexual. 2) O direito a viver a própria sexualidade sem violência, discriminação, nem coerção, dentro de um marco de relações baseadas na igualdade, respeito e justiça. 3) Pleno respeito à integridade física do corpo. 4) O direito a escolher os/as próprias compaheiras/os sexuais sem discriminação. 5) O direito a escolher ser sexualmente ativo/a, a não ser-lo, incluído o direito a ter sexo que seja consensual. 6) $\mathrm{O}$ direito a expressar a sexualidade independentemente da reprodução. 7) $\mathrm{O}$ direito a praticar sexo seguro e com prevenção de gravidez não desejada, bem como de doenças sexualmente transmissíveis, incluindo HIV. Direitos Reprodutivos: 1) decidir livre e 
responsavelmente o número de filhos e intervalo entre eles; 2) controlar seus próprios corpos; 3 ) ter sexo consensuado, sem violência nem coerção; e 4) contrair o casamento com o consentimento pleno e livre de ambas as partes. (p. 206)

A violência sexual é evidenciada nas representações e cenários culturais dos roteiros sexuais como algo que se dá em ambientes públicos. A violência sexual também é associada a lugares com venda de bebidas, como bares e boates, com representações associadas ao descontrole no uso de álcool e outras drogas. A violência conjugal, típica de ambientes privados, não combina com a expectativa que o senso comum apregoa sobre a violência sexual. No ambiente doméstico, a violência conjugal é associada aos múltiplos tipos de violência, física, sexual, psicológica, entre outros.

Antes de adentrarmos o estupro conjugal propriamente, é necessário apresentar o conceito de cena sexual, o contexto social de representações em que os roteiros sexuais se imbricam para a implementação da conduta sexual. A cena sexual, que pode ser vivida ou imaginada, é articulada a fatores que estão dinamicamente relacionados:

A idade, o sexo, a classe, a escolaridade, a raça, a religião ou ideologia de cada parceiro do ato sexual, já que a atividade sexual é um caso especial das relações sociais [...] Reflete o poder e a hierarquia entre os gêneros (homem/mulher) e entre sexualidades (heterossexual, bissexual, homossexual...). [...] Depende do sentido que se atribui ao sexo naquele contexto: prazer, troca de afeto, reprodução, descarrego, exercício de poder, construir a reputação e mudar de status na comunidade, entre outros. A cena sexual depende dos scripts sexuais (e eróticos) disponíveis, se são scripts masculinos ou femininos, do sentido e valor de cada script, e de como os personagens e atores (o “eu” e o "outro") são percebidos: amante, esposo, namorada, caso, transa de um dia, iniciador ritual, dono, propriedade... [...] Depende do que está sendo trocado no ato sexual: apoio, dependência, afeto, poder, dinheiro. [...] Depende de como se percebem as consequências e subprodutos da atividade sexual, do grau de tolerância para cada eventualidade (vínculo mais forte, rompimento, gravidez, doença, violência etc.), e da capacidade de avaliar os riscos de subprodutos indesejáveis (estupro, HIV, divórcio, filhos não planejados). Portanto a cena está sempre impregnada da personificação das normas coletivas (presença invisível da 
família, de amigos e pares, do líder religioso, da USP). A cena sexual é diferente, dependendo do lugar e horário: do tempo disponível, se está em casa, de quem é a casa, na rua, na escada do prédio, no motel, em outra cidade ou país, no trabalho, na praia etc. A cena depende também do ritmo (rapidinho ou lento). [...] Vai depender dos recursos sociais disponíveis: informações, dinheiro, contraceptivos, camisinha, quantidade de parceiros disponíveis no "mercado" etc. A cena sexual depende de recursos pessoais: aparência, capacidade de comunicação e fluência numa conversa sobre sexo, identidade sexual atribuída ou auto-referida, auto-estima, experiência sexual, apoio da família e de amigos. Finalmente, a cena é composta de práticas, ações (beijo, tipo de manipulação ou penetração), palavras ou comunicação sem palavras (gestos, olhares, posturas, ruídos). ${ }^{7}$ (Paiva, 2000, p. 222-223)

\section{Estupro conjugal}

Estupro, do ponto de vista de uma leitura que incorpore os roteiros sexuais, figura em dois planos da experiência na conduta sexual. Um dessses planos é a atuação dos personagens e suas práticas efetivas, algo que se aproxima do desempenho propriamente dito (Fontanella \& Gomes, 2015; Gagnon, 2006; Gagnon \& Simon, 2005). Outro plano da experiência na conduta sexual é a cena sexual (Bellenzani et al., 2008; Paiva, 2000, 2006), um contexto sociocultural individualizado e não generalizável, ou seja, único, que estrutura os significados das práticas sexuais.

O estupro, uma forma de violência sexual, é percebido como algo que acontece na rua, em lugares escuros e pouco frequentados, pouco conhecidos. No entanto, a análise dos dados produzidos no contexto da saúde pública indica que por volta de $17 \%$ dos estupros com vítimas adultas são realizados por cônjuges, ex-cônjuges, namorados e ex-namorados (Cerqueira \& Coelho, 2014). Os estupros por desconhecidos na mesma análise figuram em $60,5 \%$ dos casos. Apesar de o número de estupros que se dão no contexto da conjugalidade já serem altos, supõe-se que eles devem ser muito maiores. Elementos que compõem os roteiros sexuais mais frequentemente presentes nas relações

\footnotetext{
${ }^{7}$ Grifos da autora.
} 
conjugais facilitam, relativizam e naturalizam a prática da violência sexual, inclusive o estupro.

Há indícios de que o estupro intraconjugal é uma prática muito regular e mais naturalizada pelas relações de poder domésticas do que o estupro realizado por estranhos. O fato é que estupro e o sexo não violento se confundem nas conjugalidades no que diz respeito a ser ou não qualificado como violência - mesmo que envolvam práticas e consequências diferentes.

A violência sexual é marcada, em muitas conjugalidades violentas, como uma experiência sexual conjugal normalizada, mesmo que se utilize de força, ameaça ou outra forma de violação de direitos. A relativização do estupro acontece, entre outros processos, implicada na composição de narratividade que os roteiros sexuais dos sujeitos envolvidos construíram.

O estupro conjugal é aquele que se dá no contexto da relação afetivo-sexual em que os roteiros sexuais são tais que alguém não está de acordo ou não tem condições psíquicas de concordar com a conduta sexual, tendo em vista a cena sexual em que ela se dá. A prática deve ser sexual para configurar estupro, porém, os roteiros sexuais que estruturam as significações da cena como sexuais podem ser os mais diversos.

A violência sexual intraconjugal - assim como outras formas de violência que acontecem nos relacionamentos afetivo-sexuais - situa-se relacionada ao contexto atitudinal e discursivo do casal. A violência sexual conjugal não é disruptiva em relação à história do casal. Ela ocorre inserida no processo no qual o casal se fundamenta e se estrutura. Dessa forma, é importante apontar disposições dos cenários culturais, dos roteiros interpessoais e dos roteiros intrapsíquicos que compõem os roteiros sexuais que favorecem os estupros.

Cenários culturais fundamentam, além de outras condutas, as violências sexuais. As práticas sexuais são vistas como obrigação, principalmente das mulheres, nas 
relações afetivo-sexuais. Gagnon (2006, p. 254), ao refletir acerca da presença de violência sexual nos relacionamentos, afirma que:

Há variações específicas do cenário cultural para o uso 'legítimo' da força, mas todos têm a característica comum do homem cujos direitos legítimos ao sexo (em função do relacionamento) são frustrados pela recusa desses direitos por parte da mulher. O direito de o homem empregar medidas coercitivas para manter relações sexuais tende a ser tratado como mais legítimo à medida que o relacionamento assume níveis maiores de permanência e legalidade.

As perspectivas feministas de gênero apontam nitidamente uma diferença percebida e construída nos relacionamentos entre homens e mulheres que posicionam os primeiros como aqueles que têm direito ao usufruto dos corpos das segundas. Nessa relação, de alguma maneira, o cenário cultural dá conta de resguardar a demanda do homem como um direito e o consentimento da mulher frente ao requisitado como mais ou menos necessário. A depender do modo e do quanto a relação de poder se estabelece e enrijece, mais o estupro intraconjugal é intercambiável com o sexo não violento, nos termos dos discursos e práticas relacionais dos casais.

No nível interpessoal dos roteiros sexuais, aspectos relacionais podem refletir dinâmicas conjugais relativas às práticas sexuais violentas. A crença de que o casal compartilha momentos de intimidade muitas vezes não é corroborada quando se trata da comunicação entre os cônjuges acerca de suas próprias experiências sexuais. Pesquisas (Fleury, Abdo \& Marra, 2005; Risen, 2005) apontam que os casais têm dificuldade de se expor e de se comunicar sobre a sexualidade com seus parceiros, mesmo em relacionamentos duradouros.

Risen (2005, p. 9), ao se referir à falta de comunicação sobre a sexualidade na maioria dos casais, afirma que: "Muitos casais, mesmo aqueles que desfrutam juntos de uma vida sexual ativa e abundante, não necessariamente se sentem confortáveis falando 
dos seus desejos sexuais, necessidades, fantasias, ou medos." ${ }^{8}$ Essa afirmação aponta para a complexidade da interação entre desejo, afeto, necessidade, comunicação e consentimento.

A distância social que opera nas relações conjugais em torno da sexualidade facilita as situações de violência sexual, inclusive estupros. A negociação, a cooperação e a resolução não violenta de conflitos são interdependentes da comunicação. Por outro lado, a falta de roteiros sociais para iniciar e fazer fluir a conversação sobre as condutas e roteiros sexuais favorece a maior dificuldade de resolver conflitos e negociar diferenças, o que abre espaço para tensões e disputas pouco mediadas. A violência sexual se torna mais provável nesse contexto discursivo de menos tematização da sexualidade na conjugalidade.

Os roteiros intrapsíquicos também podem favorecer diretamente o estupro conjugal. Uma indicação de roteiro intrapsíquico que envolve a sexualidade do homem é a de que a atividade sexual na conjugalidade é um direito. A dinâmica interpessoal em que o homem demanda e a mulher consente provoca frustração quando esta nega e o direito se evidencia barrado pelo direito do outro de consentir ou não. Se o homem percebe a conduta sexual como seu direito, ele pode reclamá-lo como tal.

Gagnon (2006, p. 254), acerca da pesquisa que realizou nos Estados Unidos, afirma que "as agressões e as coerções sexuais observadas entre homens e mulheres que mantêm um relacionamento afetivo e sexual não-marital parecem ocorrer quando as expectativas anteriores de sexo, por parte do homem, são frustradas”.

A concepção de injustiça e ressentimento que surgem partindo da negação a um direito que deve ser percebido como inalienável fundamentam a frustração tão grande, mesmo entre casais não casados. Em um contexto em que a violência não é tão

\footnotetext{
${ }^{8}$ Tradução livre do autor principal do artigo.
} 
estrutural - em uma relação mais recente e menos legitimada - o estupro conjugal já aparece como reação a essa frustração do homem.

Gagnon (2006, p. 254) afirma algo similar sobre as conjugalidades estáveis:

No casamento, o estupro parece surgir com mais frequência em dois tipos de relacionamentos: primeiro e mais comumente, aqueles em que a mulher é fisicamente maltratada e em que a violência sexual faz parte do quadro mais amplo de maus-tratos conjugais; e segundo, aqueles em que houve dificuldades anteriores quanto à frequência da manutenção das relações sexuais ou quanto às técnicas julgadas apropriadas nos contatos sexuais do casal.

O estupro conjugal acontece mais regularmente nos casais em que a violência é parte da dinâmica e da resolução de conflitos. Mesmo em casais em que a violência não é cotidiana, quando a relação não é percebida como apropriada, o estupro é a tentativa de realinhar as práticas de acordo com as expectativas, geralmente masculinas. Diversas dinâmicas conjugais e representações podem favorecer o estupro conjugal.

Outra indicação intrapsíquica que envolve as mulheres nos relacionamentos nos quais há violência sexual está pautada por um cenário cultural da percepção do estupro. A representação está voltada para a prática sexual violenta entre estranhos em ambientes públicos ermos e bares e boates por sua associação com álcool e outras drogas (Cavalcanti et al., 2006; Machado, 1998). Essa percepção contribui para a naturalização da violência doméstica na conduta sexual. A violência sexual doméstica coaduna com roteiros intrapsíquicos presentes nas mulheres e homens que vivenciam circunstâncias em que tal tipo de violência tem maior grau de aceitabilidade. Gagnon (2006, p. 254) afirma que "o estupro por conhecidos e a atividade sexual e a atividade sexual coercitiva com conhecidos são pouco denunciados, em parte pela pouca disposição de descrever a coação no seio dos relacionamentos como violência sexual ou comportamento criminoso." 
Os roteiros sexuais envolvidos nas cenas de violência sexual e nos estupros conjugais indicam a violência como parte da narrativa conjugal. As representações comuns da violência sexual orientam o olhar para o estupro por desconhecidos em lugares públicos e o processo discursivo da separação entre vítima e agressor na experiência com as consequências do estupro.

Como indicado, por meio dos cenários culturais, roteiros interpessoais e intrapsíquicos, o estupro conjugal tende a ser mais naturalizado e menos retratado como estupro. O contexto que situa os discursos e práticas nas estruturas dinâmicas relacionais que se dão entre os cônjuges precisa ser levado em conta na análise de qualquer violência sexual intraconjugal, inclusive o estupro conjugal.

\section{Considerações finais}

A violência sexual e o estupro que acontecem nas relações conjugais precisam ser contextualizados levando em conta os significados e práticas da conduta sexual. $\mathrm{O}$ estupro perpetrado por parceiro íntimo é de compreensão desafiadora, tendo em vista as representações do estuprador como criminoso ou louco. Em contrapartida, o autor do estupro conjugal é aquele a quem se ligam representações da conduta sexual como manifestação de afeto, compromisso, ligação, intimidade, entre outros.

Os casais que vivem em situação de violência conjugal precisam ser compreendidos em um enquadre complexo. A sexualidade é apenas uma das muitas dimensões que estão presentes na vida conjugal. A produção de conhecimento que considere os vários condicionantes de violência e/ou vulnerabilidades sociais se faz necessária, pois a sociedade está longe de lidar de forma adequada com vítimas e agressores para promover menos violações.

Os processos dinâmicos discursivos e atitudinais e de inteligibilidade encontrados na situação de violência conjugal são caminhos para reconhecer 
características nas relações em que ocorrem violações sexuais e reprodutivas. A vítima de violência sexual intraconjugal lida com distorções narrativas que minimizam, justificam, anestesiam, negam, controlam e reorientam uma constelação de significados e práticas que permeiam a experiência das agressões. $\mathrm{O}$ estupro conjugal apresenta roteiros sexuais e estruturas rituais que sustentam suas contradições nas vivências da conjugalidade, o que pode favorecer a violação e ocultá-la ao mesmo tempo.

Os estudos indicam claramente que a violência conjugal comumente apresenta na mesma relação afetiva suas múltiplas facetas - psicológica, física, sexual, patrimonial, entre outras. A sexualidade intraconjugal violenta parece de difícil acesso para a produção de conhecimento. Mais estudos precisam ser realizados sobre as várias formas de violação de direitos sexuais e reprodutivos na situação de violência conjugal.

Além disso, para que a relação entre outras vulnerabilidades sociais e a violência sexual seja melhor compreendida, são necessários mais estudos sobre a conduta sexual de forma geral. As representações que situam relações entre homens e mulheres como relações de poder com posições enrijecidas desiguais permeiam toda a sociedade. 


\section{ARTIGO 3 \\ VIOLÊNCIA CONJUGAL: FAMÍLIA E ESTADO FAVORECEM PRÁTICAS E DISCURSOS DE GÊNERO E PODER}

Resumo: Este artigo discute dois estudos de caso, com dois casais que buscaram atendimento psicossocial por apresentarem violência conjugal com denúncia judicializada. O artigo investiga as construções e significações das dinâmicas da violência conjugal, com vistas a compreender de que forma as questões de gênero e poder atravessam essas relações. Foram realizadas entrevistas semiestruturadas e a construção de genogramas. Os dados passaram por análise de conteúdo. Os resultados apontam que as interações dos cônjuges — entre si, com a família ao longo da vida e com o Estado depois da violência — constroem práticas e significações que influenciam as representações, as posições subjetivas e o contexto relacional da violência conjugal.

\footnotetext{
Abstract: This article presents two case studies with two married couples who sought psychosocial treatment offered by the judicial system due to intimate partner violence. The aim was to investigate the constructions and meanings of intimate partner violence dynamics in order to understand how gender and power issues may permeate those relationships. Data was collected through semi-structured interviews and the construction of genograms. Content analysis was used to process the data. The results point out that the spouses' interactions with their families throughout their life course, as a couple and with the state right after violence lead to practices and meanings that influence representations, subjective roles and a relational context prone to intimate partner violence.
} 


\section{Introdução}

A violência doméstica é um problema social e relacional. Ela traz consequências para os indivíduos, as famílias e a sociedade como um todo (Diniz, 2013; Lamoglia \& Minayo, 2009; Waiselfisz, 2015). Pesquisa realizada no território brasileiro aponta que 40\% das mulheres entrevistadas já sofreram algum tipo de violência, cujos autores, em mais de $90 \%$ dos casos, são pessoas com as quais elas têm relações de intimidade (Abramo, 2010). Entre as participantes que responderam positivamente às perguntas "bateu ou espancou você, deixando marcas, cortes ou fraturas?" e "usou armas de fogo ou facas para ameaçar você?”, $87 \%$ e $86 \%$, respectivamente, revelaram que as violências foram perpetradas por maridos, ex-maridos, namorados, ex-namorados ou noivos, ou seja, se deram no contexto da conjugalidade. Esses dados não incluem vítimas de assassinato, já que a coleta foi realizada com as próprias mulheres.

O Mapa da Violência aponta que $71,9 \%$ das agressões contra mulheres aconteceram na residência da vítima (Waiselfisz, 2015). Além disso, pesquisa realizada com jovens de 16 a 24 anos no Brasil aponta que $43 \%$ deles já presenciaram a mãe ser agredida por algum parceiro (Instituto Avon/DataFolha, 2014). A violência contra a mulher é, em sua maioria, doméstica, pendendo para o privado na distinção público/privado e situando-se nas relações de intimidade e conjugais.

Pesquisa realizada pelo DataSenado (2013) com mulheres brasileiras de 16 anos ou mais indica que, em $78 \%$ das que sofreram violência, os autores da agressão se enquadravam nas categorias de maridos, companheiros ou namorados (65\%) e exmaridos, ex-companheiros ou ex-namorados (13\%). Essa pesquisa identificou também as razões que levam a mulher a não denunciar o agressor. A primeira razão é o medo do agressor (65,2\%); a segunda está relacionada com a dependência financeira (39,6\%); a terceira envolve a preocupação com a criação dos filhos (41\%); a quarta decorre da vergonha de revelar a agressão $(29,5 \%)$; e a quinta refere-se à inexistência de punição 
(30\%). As três primeiras categorias indicam aspectos conjugais e parentais como determinantes para a manutenção do silêncio e do segredo acerca da situação da violência (Pondaag, 2009). Todas as razões implicam a elevação do risco de novas situações de violência e/ou a manutenção da situação de violência.

A violência conjugal é uma violência de gênero (Aguiar, 2009; Cunha, 2008; Diniz, 2011; Saffioti, 2007). Os relacionamentos são sempre atravessados pelas construções e posições de gênero que os cônjuges têm e ocupam. Tais construções e posições podem assumir formas mais ou menos rígidas. A análise das práticas e dos significados para os casais em situação de violência conjugal perpassará, portanto, pela reflexão acerca dos papéis de gênero no contexto de uma sociedade patriarcal. Saffioti (2007), tratando da tentativa arbitrária de diferenciar o social do sexual no patriarcado, afirma:

\footnotetext{
integra a ideologia de gênero, especificamente patriarcal, a ideia, defendida por muitos, de que o contrato social é distinto do contrato sexual, restringindo-se este último à esfera privada. Segundo esse raciocínio, o patriarcado não diz respeito ao mundo público ou, pelo menos, não tem para ele nenhuma relevância. [...] As relações patriarcais, suas hierarquias, sua estrutura de poder contaminam toda a sociedade. (p. 54)
}

Os padrões tradicionais de gênero e as estruturas patriarcais estão presentes tanto na esfera privada quanto na pública. A violência conjugal - típica dos espaços privados, apesar das porosidades para os públicos — é muito influenciada pelo que Saffioti (2007) aponta como contrato social. A dominação masculina que representa os corpos femininos objetificados e/ou assujeitados está também na esfera privada e subsidia a violência doméstica.

A separação entre as esferas pública e privada - como se uma não fosse intimamente ligada à outra - é artificialmente reinstituída nas práticas da violência conjugal para torná-la normalizada, banalizada, invisível e silenciada. De um lado, há o 
mito de que ninguém deve interferir nas relações privadas e de que a violência, quando existe, é um problema do casal (Guimarães, 2009; Saffioti, 1999). De outro lado, a violência doméstica parece particular, já que os casais têm seus próprios modos de atuála. O fato é que a violência está extremamente disseminada. Ela é estruturada a partir de padrões tradicionais de gênero e estruturas patriarcais que circulam por toda a sociedade.

Um dos mais importantes núcleos sociais que estruturam e transmitem padrões de gênero é a família. Negreiros e Férez-Carneiro (2004), citando Goffman, propõem que o papel

é concebido como um conjunto de prescrições e proscrições para determinada inserção no meio social. Tal noção compreende direitos e deveres, com as respectivas sanções, numa determinada condição. Os papéis masculino e feminino configurariam tipificações do que seria pertinente ao homem e a mulher num dado contexto. Englobam aprovações, restrições e proibições que seriam apreendidas e transmitidas ao longo de gerações e durante o percurso da vida, do bebê ao idoso. (p. 34-35)

Referindo-se à transmissão transgeracional nas famílias, Bucher-Maluschke e Penso (2008) afirmam que:

cada membro do casal que se constitui traz consigo uma memória familiar vinculada ao que lhe foi transmitido e vivenciado em sua família de origem, a qual será repassada a seus filhos, que, por sua vez, terão a mesma missão de transmissão desses conteúdos, numa sucessão de gerações, ainda que, nessa transmissão, ocorram transformações. (p. 79)

A família é um grupo social com relações íntimas, papéis sociais interdependentes e autônomos e relações intergeracionais. Essas relações e a transmissão de conteúdos se dão por meio de vários tipos de interação. Aspectos dos papéis sociais de homens e mulheres - e relativos mais diretamente à violência 
conjugal — são alguns desses conteúdos transmitidos entre os familiares. Lisboa, FéresCarneiro e Jablonski (2007) apontam que

o conceito de transmissão intergeracional compreende a travessia de uma geração à seguinte de legados, rituais e tradições, a qual pode ser consciente ou inconsciente. [...] A transmissão intergeracional permite continuar a identidade de uma família através de um legado estruturante de rituais e mitos, por exemplo.

Um dos modos como acontece a transmissão transgeracional é a congregação familiar de mitos. Os mitos são arcabouços explicativos para elementos comuns à vida cultural e familiar. As famílias desenvolvem mitos que atravessam gerações e mantêm atreladas estruturas de significações e práticas comuns. Essas estruturas mutáveis organizam a perpetuação geracional de valores, crenças, representações e condutas. Os mitos são sistemas que contemplam elementos da realidade e atos criativos de fantasia para introduzir e explicar temas que são dimensões da vida familiar. As formulações míticas familiares se tornam, ao longo do tempo, jeitos de dar sentido e de contribuir para construções da realidade que definem relações e posições dos membros da família (Andolfi \& Angelo, 1989; Wagner, 2014).

Os rituais, por sua vez, estão relacionados aos mitos familiares. Esses rituais operam como suas expressões visíveis nas famílias, com a função de transmitir, perpetuar ou reestruturar características míticas. Andolfi e Angelo (1989) propõem que: há uma ligação estreita entre mitos e ritos familiares: consideremos estes últimos como elementos constitutivos do mito familiar, isto é, aqueles a partir dos quais ele é criado. [...] Os "ritos" são uma série de atos e de comportamentos estritamente codificados na família, que se repetem no tempo e dos quais participam todos ou uma parte dos familiares. (p. 90)

Mitos e rituais estão presentes na situação de violência privada. Cabe inserir entre rituais e mitos, a presença do segredo. Um aspecto significativo que perpassa pela identidade conjugal na relação dos casais em situação de violência é a experiência 
daquilo que não é dito (Welter-Enderlin, 2002). Silêncios, não ditos, interditos, minimizações, justificativas, negações, relativizações e outras formas de distorção dos significados e das práticas violentas sobressaem nas comunicações e interações entre os membros dos casais (Diniz, 2011, 2013; Diniz \& Pondaag, 2004, 2006; Pondaag, 2009).

Os segredos são formas de ocultar fatos contrários às expectativas estabelecidas pela família e/ou pela cultura. Os segredos são usados pelos membros da família para encobertar aspectos da vida, eles definem, ao mesmo tempo, intimidade e distância social segundo os limites entre quem sabe e quem não sabe ou quem pode e quem não pode falar sobre os conteúdos do segredo. Esse tipo de transmissão pode afetar todo o modo comunicacional da família (Falcke \& Wagner, 2014; Imber-Black, 2002). Falcke e Wagner (2014) falam sobre os impactos da manutenção do segredo:

tanto as mentiras quanto as informações omitidas podem perturbar a confiança interpessoal nos relacionamentos. Isso acontece porque, embora o evento ou o conteúdo do segredo possa ser mantido oculto, a intensidade dos sentimentos em relação a ele dificilmente pode ser disfarçada. O próprio ato de manter o segredo gera ansiedade. Quem o possui deve estar continuamente acautelando-se contra a revelação, evitando determinados assuntos e distorcendo informações. (p. 35)

Os segredos, os mitos e os rituais foram apresentados para apontar modos como a transmissão transgeracional funciona entre membros da família. Um dos conteúdos transmitidos nas famílias através de gerações são os papéis destinados a homens e mulheres e as representações que constroem as relações de gênero. A presença de mitos, rituais e segredos afeta os processos de transmissão de valores e crenças e os componentes atitudinais nas famílias ao longo de gerações; além disso, influencia os papéis exercidos por homens e mulheres na dinâmica familiar e a própria situação da violência intrafamiliar. 
Cada membro do casal em situação de violência é representante das gerações anteriores de sua família. Este artigo problematiza as construções, significações e práticas afetivo-sexuais dos casais como produto de um processo de transmissão transgeracional. Esse processo será pautado pela forma como os papéis de gênero são transmitidos e, consequentemente, atuados em contextos marcados pela violência.

\section{Método}

Este artigo apresenta dados de estudos de caso realizados com dois casais em situação de violência conjugal. O objetivo geral da pesquisa, de natureza qualitativa, foi identificar as construções e significações afetivo-sexuais que permeiam o exercício da sexualidade e analisar seu impacto na dinâmica de casais em situação de violência conjugal. $\mathrm{O}$ foco deste estudo recai sobre as construções e significações das dinâmicas da violência conjugal, a fim de compreender de que forma as questões de gênero e poder atravessam essas relações.

Entre os recursos utilizados para a construção dos estudos de caso, estão entrevistas que contemplam temas associados aos padrões de gênero, à conjugalidade, à violência e à família de origem dos membros do casal. A pesquisa teve caráter exploratório, pois conecta diferentes recursos para uma finalidade: produzir conhecimento sobre fenômenos humanos complexos, multideterminados e dinâmicos.

\section{Participantes}

Os participantes da pesquisa foram dois casais que vivenciaram situações de violência conjugal. Os casais foram selecionados por conveniência no Programa de Assistência Multidisciplinar a Vítimas de Violência - Pró-Vítima do Distrito Federal, onde trabalha o pesquisador. Os critérios para inclusão dos participantes na pesquisa foram: formar casal heterossexual; ter vínculo conjugal formal ou informal; residir na 
mesma moradia; conviver maritalmente há pelo menos um ano; ter pelo menos uma denúncia formal de situação de violência conjugal; ser maior de 18 anos. Além desses critérios, houve coincidência no fato de ambos os casais terem um filho, que mora com eles. Todos os participantes também possuem empregos formais.

\section{Procedimentos éticos e instrumentos utilizados para coleta de dados}

O estudo seguiu os parâmetros éticos estabelecidos para pesquisas com seres humanos. Ele foi submetido e aprovado pelo Comitê de Ética em Pesquisa do Instituto de Ciências Humanas (CEP-IH) da Universidade de Brasília. Os participantes leram e assinaram o Termo de Consentimento Livre e Esclarecido (TCLE). Foram aplicados: um questionário sociodemográfico para cada membro dos dois casais (Anexo 1-A); uma entrevista com cada casal para construção de seu genograma (Anexo 1-B); duas entrevistas com cada casal para construção de seu genograma sexual, uma para a família de cada membro (Anexo 1-C); uma entrevista com cada membro do casal, com questões sobre casamento, violência e sexualidade (Anexo 1-D); uma entrevista de fechamento e avaliação da coleta de dados com o casal (Anexo 1-D). Assim, o corpus que permitiu os dois estudos de caso são o questionário sociodemográfico, as entrevistas com os casais e as entrevistas individuais com os cônjuges.

\section{Estratégias de coleta e análise}

As entrevistas foram semiestruturadas e focadas no problema (Witzel, as cited in Flick, 2009). Nas entrevistas focadas no problema, o entrevistador decide momentos do roteiro em que introduz seus interesses temáticos, a fim de diferenciar os tópicos (Witzel, as cited in Flick, 2009). As induções — planejadas no roteiro ou não — vão dos conteúdos gerais para os específicos. Espera-se com essa dinâmica aprofundar a compreensão e identificar contradições e inconsistências, quando pertinente. 
As entrevistas foram gravadas em áudio e transcritas, e posteriormente submetidas a análise de conteúdo. Entre as formas de análise de conteúdo, Minayo (2010) aponta como adequada para investigações qualitativas em saúde a análise temática. Essa análise não tem como foco apenas a frequência com que um conteúdo aparece; ela prioriza a seleção de unidades do corpus associadas ao tema da pesquisa. Essa busca garante acesso a materiais que não têm necessariamente relevância quantitativa, mas podem esclarecer relações entre as unidades temáticas. A análise de conteúdo temática privilegiou a complexidade, a dinamicidade e, inclusive, os conteúdos conflitantes apresentados pelos participantes a respeito da violência conjugal. O delineamento geral da pesquisa foi de estudos de casos múltiplos, especificamente dois (Yin, 2010).

\section{Resultados e discussão}

Três categorias serão discutidas com base nos conteúdos trazidos pelos membros dos casais que vivenciaram situação de violência grave. São elas: violência conjugal e construções do poder; família e interferência conjugal; e justiça e reposicionamento da conjugalidade violenta. Em cada categoria, serão apresentados e discutidos os dados do casal V e do casal K. ${ }^{9}$

\section{Quadro 1 - Dados sociodemográficos}

\begin{tabular}{|l|c|c|c|c|}
\hline \multirow{2}{*}{} & \multicolumn{2}{|c|}{ Casal V } & \multicolumn{2}{c|}{ Casal K } \\
\cline { 2 - 5 } & Sr. V & Sra. V & 30 K & 24 \\
\hline Idade & 41 & 38 & Superior incompleto & Superior incompleto \\
\hline Escolaridade & Ensino médio & Pós-graduação & De 1 a 2 & De 1 a 2 \\
\hline Renda (salários) & De 3 a 4 & Mais de 4 & Acredita em Deus & Evangélica \\
\hline Religião & Católico & Evangélica & Branca & Branca \\
\hline Cor/etnia & Parda & Parda & & \\
\hline
\end{tabular}

\footnotetext{
${ }^{9}$ As iniciais dos sobrenomes são fictícias.
} 


\section{Violência conjugal e construções de poder}

\section{Casal V}

A situação que fez o casal V chegar ao Pró-Vítima é narrada pela Senhora V: eu subi as escadas. Eu estava sozinha esse dia. O filho ${ }^{10}$ estava na casa do meu pai. [...] Na hora em que eu fui fechar a porta, ele veio com tudo correndo. Tanto que eu pensei que era um ladrão. Ele pegou e empurrou. “Ah, você aí!” Ele falou assim: "Como é que é? Você não faz isso comigo." Eu falei: "Senhor V, pelo amor de Deus! Você está bêbado, tem a medida protetiva. Pelo amor de Deus, vai embora!” Ele: "Não, não sei o quê...” Pegou assim: "Você vai! Eu quero fazer amor com você." Eu falei: "Não, eu não quero." E ele: "Você vai fazer, sim!", bem transtornado. "Você vai fazer amor!" "Não, eu não quero." Aí foi lá no quarto. "Não, eu não quero. Calma, vamos conversar." Ele assim, super alterado. Nessa hora, eu falei: "Não adianta eu medir forças com ele!" Aí foi na hora que eu cedi.

A Senhora V contou diversas cenas de sua vida que envolviam formas de controle e violência por parte do Senhor V. Ela narrou um episódio, depois de um término entre eles, em que estava com outro homem em um bar:

eu estava de costas e a pessoa do lado. Aí ele pegou e deu um tapa na cadeira. Eu: "O que foi?" "Você vai embora agora!" "Não vou." Aí ele: "Você vai!" Pegou a chave do meu carro... Não, pegou os meus documentos. Pegou: "Você vai!" Me puxando assim. Falei: "Me solta, me solta!" O pessoal do bar: "Vamos chamar a polícia, vamos chamar a polícia." Aí ele pegou, rasgou a minha roupa. "Você não vai sair?"

A Senhora V interpreta a intenção dele ao rasgar sua camisa: “Que eu voltasse para casa. Porque assim, ela está rasgada: 'Não vai ter coragem de sair”'.

A agressão do Senhor V a terceiros é descrita por ela em outras cenas: "Quando ele ficava me seguindo... Aí se ele via uma pessoa, ele queria agredir essa pessoa. Um

10 Os conteúdos itálicos nas falas dos membros dos casais são alterações para não identificar os participantes. 
amigo meu, ele: 'Ah, eu vou matar.' 'Você quer acabar com o meu casamento". A Senhora V relatou que foi seguida sem perceber: "Ele veio, agrediu um colega meu. A gente estava sentado num barzinho, eu, minha amiga e mais outro colega". E mencionou também agressão a ela e outros: "Passamos por situação assim, de ele me agredir porque eu já estava com outra pessoa, de ele agredir a pessoa. Porque não aceitava esse fim”. Sobre os terceiros, afirmou: “Gente, assim, que não tinha nada a ver com a nossa história".

A Senhora V relatou ameaças à vida dele e à dela: "Foi um dia que ele seguiu e me agrediu, dizendo: 'Você vai morrer hoje comigo'. Me colocou dentro do carro. Falou: 'Você vai morrer. Se você não fica comigo, nem com ninguém'”. Os relatos da Senhora V indicam a presença de mecanismos de controle e ameaça. Ela relata como constante a dinâmica de ser seguida: "Essa perseguição, que ele não parava de me seguir". "Todo lugar que eu ia, ele aparecia. Eu falei assim: "Você colocou um GPS no meu carro"".

O abuso sexual foi outra forma de controle usada pelo ex-parceiro. Nos momentos que antecediam o estupro conjugal, ela era surpreendida por uma situação de espreita: "Quando eu chego em casa, acho que ele já estava em algum lugar ao redor me esperando. Mas eu não vi o carro ali por perto. E às vezes ele ficava sentado na parada de ônibus esperando". O Senhor V também interferia na relação da Senhora V com terceiros:

Ficou aquele ciúme doentio que eu não podia nem ir na padaria sozinha. Aí eu falei pra ele que não aguentava mais. Eu falei: "Não aguento mais isso. Não quero. Me sinto presa. Eu não posso ter um contato com a minha família, com minha irmã”. Se alguém fosse lá em casa, ele ficava o tempo inteiro de cara feia. [...] Se eu levasse para sair num lugar comigo, era cara fechada o tempo inteiro. Se a pessoa falasse com ele, nem respondia.

Ele tentava controlar os contatos dela. Invadia sua privacidade via controle do celular: “A questão de querer pegar o meu telefone. Às vezes, na hora dele pegar meu 
telefone, ficava uma marca. Ele: 'Vou pegar seu telefone, porque esse telefone...' Era sempre essa neura de pegar meu telefone, para ver o que que tinha no telefone". Ele também investia em controlar suas saídas: "Eu não podia, porque não era só com homem esse negócio. Era até se eu fosse na casa de uma avó, se eu falasse com uma amiga. Eu ia, mas quando eu voltava, ele estava brigando porque eu tinha saído”.

A Senhora V relata que, além da obsessão pelo controle, as tentativas de contato dele eram invasivas: "Ele ficava aparecendo lá em casa do nada. Aí era mensagem toda hora. A tortura psicológica também era assim: 'Ah, você me deixou'. Era mensagem no Whatsapp, coisa que eu não aguentava mais”. Todos esses exemplos revelam a presença do que é chamado, na literatura, de terrorismo íntimo.

O terrorismo íntimo é caracterizado pelas tentativas de dominação do parceiro íntimo e pelo controle geral da relação, manifestas por meio de ampla variedade de estratégias de imposição de poder e controle, inclusive a violência. O controle coercitivo se dá de tal modo que mesmo estratégias que, em outras relações, seriam não violentas ganham contornos e significados violentos, por se darem em uma conjugalidade que apresenta ameaças, abuso emocional, intimidação etc. (Johnson, 2006; Johnson \& Leone, 2005; Leone, Johnson \& Cohan, 2007).

Em outro casal, alguns desses comportamentos poderiam ter uma interpretação romântica - o homem esperar a mulher chegar na parada poderia ser um carinho, e o desfecho poderia ser um encontro amoroso pleno. No caso da Senhora V, essa é uma cena que desperta medo e terror, pela sensação de insegurança em uma relação violenta, que a situação contada corrobora, pois tem um estupro como desfecho. O Senhor V evita falar dessa cena, mas parece muito pesaroso cada vez que qualquer conteúdo associado a ela aparece na conversa, tanto nas entrevistas individuais, quanto com o casal. 


\section{Casal K}

A cena que fez o casal K chegar ao Pró-Vítima é narrada pela Senhora K:

Quando ele voltou, ele já voltou um pouco estranho, sem falar direito comigo. Tentei conversar:

"E aí, como é que foi a viagem? Você não mandou mensagem." Porque ele quase não tinha mandado mensagem durante a viagem. Não tinha ligado, nada. Mesmo eu tentando falar com ele, ele já ficou meio estranho.

A tensão continuava no dia seguinte:

Quando foi no dia seguinte, ele não dormiu na cama, preferiu dormir no sofá. Quando foi no outro dia, quando eu cheguei em casa, ele já estava no sofá. Ele já tinha chegado. Peguei a criança $K$, levei lá pra casa. [...] Já era noite, já ia virar o dia. Aí eu cheguei em casa. Aí eu tentei pressionar: "O que que está acontecendo? Por que que você está no sofá? Vamos dormir lá na cama comigo? O que que foi, o que está acontecendo?” Aí ele: "Não dá, me deixa! Eu estou com sono, eu estou cansado". "Não, a gente vai conversar. [...] O que que você não está querendo falar comigo, que você está todo estranho? Vamos dormir lá!" "Não, não quero. Vou ficar aqui e não vou dormir lá e não quero conversar."

\section{A cena continua e a esposa relata que falou:}

“Não, a gente vai conversar". Puxei a coberta dele. [...] Tentei pressionar ele de alguma forma. [...] Fiquei com raiva. Falei: "Cadê o dinheiro do aluguel?" O nosso aluguel eu já tinha pago, já tinha recebido. Falei: "Eu preciso da sua parte do aluguel para comprar as coisas do aniversário da criança $K^{\prime \prime}$. O aniversário de um ano dela seria dias depois, e a gente iria fazer um bolinho no sábado. Ele: "Eu não tenho dinheiro, não". Eu falei: "Pois é, acontece que eu estou precisando. E agora? A gente precisa fazer o bolinho da criança $K$ ”. Ele "Ah, me deixa em paz. Eu não quero conversar agora.” [...] Ele: "ah, me respeita, me respeita!"

\section{Nesse momento, a Senhora K também decide mostrar que não era respeitada.}

Falei "Não, você também não me respeita". Nisso a gente começou a discutir. Aí eu pressionei. Aí ele veio para cima de mim. Começou a me agredir, me dar socos. Eu pedia para ele parar e ele não parava. Até que de uma hora para outra ele parou. Me olhou assim, como se estivesse meio 
que em choque também. Deitou no sofá e voltou a dormir. Eu fiquei em estado de choque. Peguei a criança $K$.

O Senhor K relata:

Ela estava pressionando minha barriga com a mão. Ela é meio fortinha. Ela pressionou minha barriga com a mão, com as duas mãos inclusive, e puxou meu edredom. Eu explodi. Se eu não me engano, ela caiu de joelho, no sofá. [...] No sentido contrário do sofá. Eu só lembro dos choros. Chorando, chorando. A criança $K$ chorando, ela chorando. Ela levantou e já foi para a casa da mãe dela. Eu fiquei meio que chocado. Eu estava dormindo na verdade. Eu levantei no susto. Eu levantei no susto.

$\mathrm{O}$ casal $\mathrm{K}$ contou que, durante suas discussões, eles costumam ser agressivos verbalmente. No entanto, essa é para eles a cena mais emblemática da violência conjugal. A violência conjugal situacional é diferenciada do terrorismo íntimo, por ocorrer em situações específicas, possivelmente com escalada da violência. Esse tipo de violência é mais bem compreendido em uma perspectiva que leve em consideração os conflitos conjugais. Eles são parte de qualquer conjugalidade, mas em alguns casais, uma ou mais vezes, alcançam o nível de uma violência mais grave (Johnson, 2006; Johnson \& Leone, 2005; Leone et al., 2007). Apesar de o Senhor K indicar, às vezes, que foi uma cena de resistência violenta, o enquadre de violência conjugal situacional é mais adequado, seguindo essa divisão terminológica.

Embora o terrorismo íntimo se diferencie de violência conjugal situacional, nenhuma cena é descontextualizada da vida geral do casal. As representações de violências e controles do casal $\mathrm{V}$ e do casal $\mathrm{K}$ revelam-se não somente nas cenas de violência entre eles, mas também em outros momentos e associadas às representações e práticas que perpassam pela vida familiar. Vale ressaltar que as famílias de origem de ambos os casais são repletas de conflitos e situações violentas. 


\section{Família e interferência conjugal}

É comum a violência ser fruto de um processo de transmissão transgeracional. A presença de violência nas famílias de origem pode resultar em um aprendizado que normaliza esse tipo de dinâmica na vida relacional. É fundamental, portanto, conhecer a história familiar de casais em situação de violência.

\section{Casal V}

O Senhor V relata que conviveu com violência doméstica:

Pai também era alcoólatra, bebia bastante. De vez em quando, tem aquelas discussõezinhas internas em casa. Depois da bebida, ele queria ter agressão com mãe. Até quando eu fui entender de alguma coisa, fui crescer, que eu fui interferir. [...] Uma vez por mês, era mais quando chegava o próximo pagamento, porque aí sobrava um dinheirinho, ele ia tomar as pinguinha dele. [...] Com os filhos, não. Foi somente mesmo com mãe.

A Senhora V também relatou uma situação com os pais: "Quando teve a separação, que ele foi para cima da minha mãe, porque ele não era assim. Aí eles já separaram".

O Senhor V sofreu violência com função de controle corretivo:

Eu estava sentado no sofá. Do jeito que ele veio com o cinto, e vap, vap, vap. Nem perguntou nada. Desceu aquela surra boa. E nesse momento da surra o cinto foi e bateu no meu olho. $\mathrm{Na}$ mesma hora o olho ficou desse tamanho. [...] Aí perguntavam o que que era aquilo e eu não tinha nem coragem de falar que tinha sido meu pai. Naquele exato momento, ficava mentindo, inventando alguma coisa. Mas foi um acidente. [...] Mágoa nenhuma, mágoa nenhuma. Principalmente porque era um jeito de educação, de educar os filhos. Então, a recomendação foi dada.

A Senhora V também contou ter vivenciado uma educação com controle violento: 
Naquela época, coisa de adolescente. De querer enfrentar e ele, como pai, não aceitar que eu passasse por cima dele. Às vezes dava um tapa. Eu já não aceitava essas coisas assim. Mas no mais, acho que não era nem questão de violência. Era ele querendo impor a condição dele de pai. Que eu também não estava respeitando.

Nas famílias de origem, a violência era percebida como um recurso normal de correção e controle. A tentativa de controle violento do pai da Senhora V é associada à perda do poder de decisão do fim do relacionamento com a mãe. O pai do Senhor V, por sua vez, agredia frequentemente sua mãe, tendo o álcool como fator precipitante. A agressividade na interação com o outro é percebida como um modelo a reproduzir. É comum, nas situações em que a geração dos pais apresenta violência conjugal, o aprendizado de que a família e a conjugalidade têm como fatores estruturantes a agressividade e a violência (Colossi \& Falcke, 2013; Razera, Cenci \& Falcke, 2014).

A Senhora V relata ausência de assistência dos familiares do cônjuge:

eu não escondi a situação para eles. Falei tudo que estava acontecendo. Falei: "Isso vai prejudicar ele no local de trabalho". Liguei para a mãe dele, "Senhora U., conversa com ele, porque ele tem que aceitar [o fim do relacionamento]”. Falei com o irmão dele.

Houve um período em que ele estava preso e outro em que estava internado no hospital. A Senhora V buscou ajuda e não recebeu. Ela explica:

Porque a família dele é muito distante. Até essa questão de ficar no hospital. Às vezes ninguém podia e ele precisava de alguém. [...] Até a questão dele na prisão, de pedir as coisas, era eu que levava. Porque se dependesse da família dele. [...] Porque eu sei que eles não iam ajudar. Como assim, até para ficar no hospital... Se fosse, tinha que pagar para a família ir lá ficar. [...] Não vou deixar ele sozinho, por mais que tenha me feito sofrer. 
A cena que fez com que ele ficasse internado, pelo que conta a Senhora V, foi uma cena em que ele pegou o celular dela transtornado, acusando-a de ter contato com um suposto amante. Ela relata o pedido de ajuda por meio de intervenções familiares:

eu liguei para minha mãe. Aí ele pegou, tirou todos os telefones. Eu falei: "Mãe, vem para cá, que $V$ está doido". [...] Foi minha mãe, meu cunhado e minha irmã. Quando chegaram lá, minha irmã falou assim: “Ah, você está querendo o quê? Porque você, eu vejo direto. Não dá valor para minha irmã, não. Sexta-feira mesmo eu te peguei com uma mulher lá no local de entretenimento frequentado pelo Senhor $V^{\prime}$. Minha irmã vivia vendo ele com mulher. Aí ele foi para a janela. [...] Eu falei: "Mãe, parece que ele vai pular". [...] Minha irmã até brincou: “O quê? Vaso ruim não quebra, não”. Quando chego lá, ele botava sangue pelo nariz, pela boca e pelo ouvido.

A Senhora V relata acusações da família de origem dele com base no incidente em que o Senhor V pulou do primeiro andar: "Quando eu fui para o Hospital, o homem falou do risco de morte altíssimo dele. 'Ele vai morrer. Não vai sobreviver, não.' Aí outra coisa, a família me acusando porque achava que eu tinha empurrado ele da janela".

Depois do estupro relatado anteriormente, a Senhora V contou: "Ele foi embora. Aí quando eu saí de lá, já liguei para minha irmã. 'Não, não. Vamos para a delegacia. Vamos para a delegacia.' Que eu fiquei bem perturbada. Aí foi na hora que, depois de um tempo, ele já foi preso”. As intervenções das duas famílias de origem depois dele preso também são relatadas pela Senhora V:

Depois todo mundo entendeu: “Não, Senhora $V$. A gente sabe. Ele é uma pessoa boa”. A família dele ficava só me julgando, mas a minha família teve um carinho com ele, uma coisa tão grande. [...] Da minha família, todo mundo que ele colocava fazia questão de ir [visitar o Senhor V preso]. E ficava: "Você vai sair daqui. Você vai sair dessa. A gente sabe que você é uma pessoa boa”. 
A narrativa acerca da presença e das formas de interferência das famílias de origem na conjugalidade violenta indicam posturas diferentes. A Senhora V, mesmo perturbada, contou com a ajuda da irmã e conseguiu fazer uma denúncia logo após o estupro. A família dela também foi capaz de interferir no ambiente doméstico e socorrêla em situações extremas - quando o Senhor V a estava ameaçando e pulou do primeiro andar; e depois apoiando-a em situações difíceis, quando ele estava preso. A ausência de suporte da família de origem do Senhor $\mathrm{V}$ - que vivenciou violência conjugal constante na infância — parece acentuar a vulnerabilidade experimentada na conjugalidade atual, marcada igualmente por manifestações de violência.

A experiência de violência na geração anterior pode diminuir a capacidade de proteção das vítimas, além de reiterar a banalização e naturalização da violência conjugal. Nesse contexto, as pessoas envolvidas aprendem a não esperar ajuda, e tendem a não vislumbrar um meio de escape da situação ou de mudança (Oliveira et al., 2009; Renner \& Slacker, 2006; Walker, 2009). A Senhora V, que presenciou cena de violência conjugal ocasional na sua família de origem, parece contar mais com a ajuda da família e tê-la mais receptiva.

A maioria das mulheres em situação de violência conjugal não procura ajuda no sistema legal ou de saúde (Narvaz \& Kohler, 2006). A fonte de ajuda mais procurada nas violências conjugais graves e não graves é a família de origem, em primeiro lugar, e a família do companheiro, em segundo (Bruschi, Paula \& Bordin, 2006). Para o casal V, fez grande diferença a família da Senhora V ter competência para dar suporte e oferecer socorro quando demandada. Já a ausência de apoio da família de origem foi fator de risco para a reincidência e o aumento da gravidade da violência na família constituída pelo Senhor V, ao não oferecer suporte adequado quando necessário. 


\section{Casal K}

O Senhor K afirmou que as relações com a família de origem da Senhora K são marcadas pelo isolamento. Ele também se sente isolado e discriminado: "Não, totalmente isolado. Até hoje, nunca houve. Desde o princípio foi assim. Agora mais ainda por causa do fato [a violência física perpetrada por ele]. Discriminado por todos”. Ele afirma sobre o pai e a família:

nunca tivemos contato nenhum. [...] Nunca um "bom-dia!", "Boa-tarde!” Eu sinceramente nunca fui tão destratado, em toda a minha vida, igual é nessa família. Meu casamento parece que é uma piada, tem hora. Acho que entrei de gaiato no navio total, porque não há vínculo nenhum de relacionamento.

A Senhora K, ao falar sobre a relação da família com ele, diz: quando ele ia, não se sentia bem. A família, querendo ou não, sempre foi muito na dela. [...] Então quando ele ia para algum lugar comigo, ficava comigo e só. A família nunca foi de entrar para conhecer e nem ele também foi para conhecer. Então sempre houve esse distanciamento.

O Senhor K reconhece a presença de relacionamento igualmente difícil entre sua mãe, única familiar com quem tem mais contato, e a Senhora K:

família para mim é minha mãe. Não, [a Senhora K] é intolerante: "Porque ela não foi com a minha cara”. É sempre o mesmo discurso. Minha mãe sempre foi enfática de não gostar de certas posturas dela em relação a mim. Depois de namorar, já, se casar. Mas naquele momento que ela enfatiza como ponto pacífico, de que minha mãe não foi com a cara dela e pronto. Acabou e morreu. Eu que tenho que engolir isso. Não sai disso. É impressionante, é uma coisa que eu realmente não consigo entender. É difícil, muito difícil.

A Senhora K fala de situações em que a mãe do Senhor K foi agressiva com ela: foi o nosso casamento religioso. Ela já chegou lá, no lugar [...], passou por mim e: “Ah, assim não vai dar certo! Você trata de tomar jeito". [...] Eu não estava entendendo o que estava acontecendo. Não sei, realmente não sei o que tinha acontecido. [...] Quando foi no outro dia, 
ela... A gente conversando e tal, ela falou assim em tom de brincadeira: “Ah, vou te matar! Da próxima vez que você for lá em casa, eu vou te matar”.

A Senhora K relata que a animosidade continuou. Logo depois do casamento, aconteceu a seguinte situação: "Eu fiquei um mês adoecida, passando mal todos os dias. Com dor de cabeça, com enjoo. Enfim, passei um mês assim me sentindo mal. Aí teve uma vez que ela estava com a gente e era um dia que eu estava passando mal. Ela falou assim: "Você não casou pra cuidar de uma doente"'. A Senhora K narra o que ocorreu meses depois:

eu descobri a minha gravidez. Dias depois, eu vi uma mensagem no celular dele: “Aborta logo!" Eu entendi que era ela pedindo para abortar. Porque, quando eu engravidei, ele sugeriu que eu abortasse a criança. Eu falei que não. [...] Aí, quando foi num sábado, eu estava tendo um pequeno sangramento. Fomos ao hospital. Estava tendo um pequeno descolamento de placenta. Aí foi aquelas recomendações: "Você vai ter que ter repouso". [...]

No outro dia, de manhã, [...] a mãe dele chega lá na nossa casa e ele vai pra praça com ela. [...] Cheguei lá na praça, ela falou: “Oi!” Aí eu fiquei calada. Não conseguia responder, porque eu entendi na mensagem que era aquilo. Ele falou: "Não vai falar com a minha mãe, não?" Falei: "Não, não sou obrigada a falar com quem quer matar o meu filho".

A Senhora K conta o ato contínuo: "Ela começou a me bater, a me dar tapa, me dar tapa, só que foi tudo tão rápido. Ele me segurou e ela meio que me afastou. Falou: 'Você é louca, eu sou sua mãe. [...] Mãe tem direito de bater no filho'. Eu virei para ela e falei: "Você não é a minha mãe"”.

Quase um ano depois do nascimento da filha do casal K e três semanas antes da cena de violência grave entre o casal, ou seja, a violência que gerou a denúncia atual, outros conflitos familiares bastante agressivos ocorreram depois de a mãe do Senhor K dormir sucessivamente na casa do casal: 
“Tudo bem, mas que essa seja a última vez". Isso no banheiro, só eu e ele conversando. Quando eu saí do banheiro, que ele estava tomando banho, ela já veio para cima de mim: “Ah, você não manda em nada! Você não cuida nem da sua filha! Como é que vai falar de alguma coisa!? Você é uma porca igual a sua mãe!” [...] Falei: "Eu não quero discutir com a Senhora”. Falei isso num tom firme. [...] Aí eu entrei no banheiro de novo. Abri a porta de novo. Falei assim: "Pede para a sua mãe parar, porque eu não vou ficar aceitando sua mãe me difamando, falando de mim aqui na minha casa". Na mesma hora ela veio, puxou os meu cabelos assim, com força pra trás. Ele estava tomando banho e falou: “Mãe, para! Para! Para! Para!” Eu falei: "Ela vai embora dessa casa agora".

\section{A Senhora K continua o relato:}

saí, fui na minha mãe deixar a criança $K$. Chamei a minha tia, a minha tia que sempre se deu muito bem com ele e comigo. Fui lá e falei: "Ela não dorme aqui. Ou ela sai daqui, ou eu vou na polícia”. [...] Eu fui para minha mãe para supostamente pegar a neném. Quando eu estava saindo, ela falou [...]: "Nunca vi, nunca vi puxão de cabelo matar ninguém, da próxima vez vou matar de verdade!” Minha tia ouviu. Minha tia: “Olha, Senhora, isso que você está falando é muito sério! Você acabou de ameaçar minha sobrinha!" Ela falou: "É isso mesmo, da próxima vez eu mato ela".

Fica evidente a presença de violência na família de origem do Senhor K. Sua mãe revela, por meio de suas falas e atitudes, que recorre à violência como forma de exercício de autoridade e poder. Trata-se de uma situação de transmissão transgeracional de estratégias de resolução de conflito marcadas pelo uso da violência.

Os termos "transgeracional" e "multigeracional" são usados, em muitos trabalhos, de forma intercambiável (Wagner, 2014). No presente artigo, “transgeracional” refere-se à herança familiar transmitida de uma geração à outra que o representante do casal reproduz de alguma forma. Já "multigeracional” é a ação ou presença de representantes de mais de uma geração que fazem uso do mesmo conjunto de práticas ou significações. No momento em que o Senhor K e sua mãe perpetram 
violência contra a Senhora K, podemos falar de uma violência multigeracional, ou seja, mais de uma geração está envolvida na reprodução e manutenção de práticas e representações transmitidas de forma transgeracional. A violência conjugal como fenômeno transgeracional é bastante descrita na literatura (Colossi \& Falcke, 2013; Narvaz \& Kohler, 2006; Ribeiro \& Bareicha, 2008).

A díade formada pelo Senhor K e sua mãe manifesta a expressão de uma violência multigeracional na conjugalidade violenta. A violência, que parecia situacional quando contada com base nas violências intraconjugais, revela, na verdade, um processo de terrorismo familiar quando os conflitos familiares são iluminados pelos depoimentos. A análise aponta questões de herança familiar e revela a coparticipação multigeracional na situação de violência.

O Senhor K conta que, depois da cena em que espancou a Senhora K, ela e a criança K passaram a morar na casa dos avós maternos. Ele revela:

Eu fui lá visitá-la. [...] O pai dela, assim que ele me viu, ele já entrou lá para dentro. Já saiu com a faca na mão, em frente de todo mundo na rua, crianças, jovens, senhoras. Todo mundo vendo ele atrás de mim. Tive que correr quase quatro quadras. Ele com uma peixeira, falando que ia me matar.

A Senhora $\mathrm{K}$ fala do comportamento de seu pai no dia em que houve o espancamento: "Ele foi, pegou a faca, porque queria ir lá no Senhor K. A gente não deixou". Ela narra a conversa que teve com o pai depois da tentativa de assassinato: "Falei que as coisas não era assim, ele errou, mas que ele tinha direito a uma segunda chance, assim como meu pai tinha tido uma segunda chance depois do que ele tinha feito comigo". A Senhora K então se refere a algo que o pai tinha feito com ela quando criança: "Meu pai começou a discutir com a minha mãe. [...] Fui para o quarto. Fui para o meu quarto e bati a porta do quarto, com raiva, porque meu pai brigava muito com a 
minha mãe. [...] Nisso, meu pai veio e me pegou e bateu minha cabeça várias vezes atrás da porta". ${ }^{11}$

Ela continua: "A gente nunca conversou a respeito. Ele nunca me pediu desculpas. [...] Na minha cabeça, eu era uma criança. Estava com raiva porque os dois estavam discutindo". A Senhora K relata uma conversa subsequente com sua tia sobre o evento: "Minha tia: 'Mas ele não te agrediu tanto, foi só um tapa. Foi só um tapa mais de correção do que eu lembro'. Eu falei: 'Não tia, não estou falando desse episódio. Eu estou falando de quando eu era criança, que meu pai pegou e bateu a minha cabeça atrás da porta'. Ela falou: 'Nossa, eu não sabia!'”

A associação feita pela Senhora K entre a violência perpetrada pelo pai contra ela, aos 9 ou 10 anos, e pelo Senhor K, na idade adulta, indica semelhança entre a submissão que ela tinha quando criança, na relação com os pais ou adultos, e a submissão doméstica em um novo relacionamento, dessa vez conjugal. A submissão, cultural e familiarmente exigida das crianças, é naturalizada, como indica a conversa com a tia.

A submissão doméstica da esposa e a responsabilidade pelas tarefas domésticas também aparecem nas falas da díade formada pelo Senhor K e sua mãe como motivos para "disciplinar" a parceira. Experiências, valores e mitos culturais patriarcais, androcêntricas e adultocêntricas representam as mulheres e as crianças sob a dominação masculina, muitas vezes violenta. Mesmo não percebendo, homens e mulheres perpetuam e reproduzem a violência e outras assimetrias estruturantes da cultura em suas relações de gênero e geração (Guedes \& Moreira, 2010; Ribeiro, Rosso \& Martins, 2004).

As reações fusionais presentes no casal $\mathrm{K}$ e entre os cônjuges e suas famílias de origem são manifestadas por meio de expressões de aniquilamento. A mãe do Senhor K

\footnotetext{
${ }^{11}$ A senhora $\mathrm{K}$ faz um gesto que indica que o pai segurava a porta e batia contra a cabeça dela, a qual
} ficava prensada entre a parede e a porta. 
ameaça a nora de morte constantemente e a agride fisicamente a partir do casamento do filho, momento crucial para a experiência ansiosa advinda da mudança do ciclo de vida de uma mãe que dedicou a vida ao filho. A Senhora K — com grau de fusionamento ao Senhor K - rompeu relações com a sogra, que se mantém interferindo na dinâmica relacional do casal por conta do apoio dele.

O Senhor K, por sua vez, tem relações rompidas com a família da Senhora K, que é buscada ansiosamente a cada problema apresentado pelo casal. O pai da Senhora K, representante da intervenção de sua família de origem, busca solucionar os problemas no casamento da filha por meio da tentativa de homicídio do genro em dois momentos: na situação de violência e quando ele retorna para ver a filha do casal $\mathrm{K}$. Apesar de confrontar o pai quando ele age de forma grave, a Senhora K o apoia e compreende.

Esses processos revelam dificuldades de diferenciação do eu em relação às famílias de origem. A diferenciação do eu - conceito central na Teoria dos Sistemas Familiares de Murray Bowen — é parâmetro fundamental para identificar o grau de maturidade (autonomia) ou imaturidade (indiferenciação) em relação às famílias de origem. As dificuldades de diferenciação estão particularmente relacionadas à presença de alto grau de ansiedade ou tensão no sistema familiar.

Os membros menos diferenciados são mais dependentes dos ambientes relacionais para o equilíbrio e o bem-estar. Ao vivenciarem processos que provocam mudanças no ambiente, esses membros menos diferenciados têm mais dificuldade de criar percursos individuais. Nesses contextos, tendem a retornar ansiosamente à família de origem à qual estão vinculados. As polaridades reativas que surgem nos contextos de indiferenciação são a fusão e o rompimento (Bueno, Souza, Monteiro \& Teixeira, 2013; Papero, 2014). 
O modelo de funcionamento dessa família parece operar por meio de uma dinâmica em que o aniquilamento do outro ou o rompimento drástico é a forma de resolução de problemas diante da ansiedade que se apresenta nos triângulos. As duplas indiferenciadas parecem funcionar com plenitude de fusionamento, com base na destruição do triângulo. Assim, as duplas Senhor K-mãe, Senhor K-Senhora K e Senhora K-pai permanecem conectadas pela fusão e pelo rompimento de pelo menos uma das partes envolvidas como terceiro.

Essa aproximação com o conceito de indiferenciação de si para entender o funcionamento desses casais e famílias não indica um caráter psicopatológico nem a valoração das ações. Por um lado, é bom que a Senhora K possa procurar apoio na família ou ter com quem deixar a criança $K$, mas é importante vislumbrar a ansiedade por trás das respostas reativas nas tentativas de fusão e rompimento. A Senhora $\mathrm{K}$ relatou eventos mais recentes na relação com o Senhor K e deste com sua mãe:

Eu cheguei em casa do serviço, me deparo com a mãe do Senhor $K$ fazendo as coisas dentro da minha casa, lavando sei lá o quê. Pegou um balde, que estava fazendo sei lá o quê. Eu virei para ele e falei: "Eu não quero que sua mãe faça nada na nossa casa". Ele: "Ah, mas eu quero". Eu falei: "Mas eu não". Ele: “Ah, direitos iguais”. Eu falei: "Então tá. Vou trazer o meu pai para cá”. A gente começa a falar coisas meio chatas [risos da Senhora K]. Ele: "Ah, então traz mesmo, que eu aproveito e mato ele aqui mesmo".

Elementos transgeracionais favorecem a violência conjugal e violências multigeracionais estruturadas nas díades familiares que envolvem o casal $\mathrm{K}$. A violência, mesmo que intraconjugalmente seja considerada situacional, nunca se dá ao acaso. Ela é percebida como recurso corretivo e como estratégia de resolução de problemas desde a infância, tanto na relação entre os pares como na submissão das crianças aos adultos. Na última discussão, em que a mãe do Senhor K é novamente percebida como uma presença intrusiva, as díades são incorporadas nas falas 
intraconjugais. Essas falas envolvem ameaças mútuas e explícitas, ambas contra a vida, ou seja, a possibilidade de resolução do problema é dramática: passa pelo aniquilamento. Fica evidente, nesse caso, que a violência multifamiliar é marcada pelas heranças familiares transgeracionais, por crenças, valores e mitos que agenciam as narrativas, contribuindo para perpetuar a situação de violência intraconjugal.

\section{Justiça e reposicionamento da conjugalidade violenta}

\section{Casal V}

A Senhora V conta sua reação ao ter a camisa rasgada: "Foi a primeira ocorrência que eu fiz. A gente foi para aquele NAFAVD. Fizemos encontros". ${ }^{12,13}$ Ela relata sua experiência nos grupos frequentados por decisão judicial: “É diferente, porque lá o pessoal não quer se expor”. Ela compara essa situação com a situação de entrevista, em que está sozinha ou somente com o cônjuge.

O Senhor V relata dificuldade similar na experiência com o NAFAVD: "Quer se abrir para poder falar: 'Não, eu fiz isso, isso e aquilo. Não, aconteceu isso e isso'. Um ou outro que realmente não está nem aí. Ele se desabafa mesmo”. Ele continua:

\footnotetext{
Achei bom. É o que eu falo, no início ninguém quer. Você tem que estar lá. Todo dia útil e dia útil você tinha que estar lá. [...] No trabalho do Senhor $V$ tem dias bons. Tem cara que é tranquilo, que entende que você precisa fazer aquilo ali. Mas tem outros que não. Começam a virar a cara para você. Então para mim foi ruim só essa fase. Mas graças a Deus consegui fazer. [...] E para mim foi muito valioso. [...] Foi muito bom. Muito legal.
}

12 O Núcleo de Atendimento à Família e Autores de Violência Doméstica (NAFAVD) é um órgão da Secretaria de Estado de Políticas para as Mulheres, Igualdade Racial e Direitos Humanos do Governo do Distrito Federal. Apesar de serem órgãos do Executivo, auxiliam diretamente órgãos do Judiciário no atendimento aos envolvidos nas situações de violência doméstica.

13 O NAFAVD, assim como a polícia, o juiz e as equipes psicossociais dos tribunais são considerados parte do sistema de Justiça. Este conta com a segurança pública, o Judiciário e órgãos vinculados, pois os membros dos casais estudados, apesar de perceberem funções diferentes dos atores nos órgãos, veem os últimos como uma constelação única de representação do Estado perante um crime. 
O Senhor V aponta como crítica aos grupos o fato de eles serem obrigatórios e de desconsiderarem seu horário de trabalho. Apesar desses aspectos negativos, achou o processo valioso. $\mathrm{O}$ casal $\mathrm{V}$ parece ter encontrado mais dificuldade de se abrir no contexto da modalidade grupal. Durante as entrevistas, no entanto, o Senhor V apresentou algumas reflexões acerca de gênero e dos tipos de violência que a mulher sofre agora - antes desconsideradas - que parecem ter resultado das discussões efetuadas nesses encontros. Estudos indicam a importância desse trabalho com os grupos vinculados à Justiça para a prevenção de violência doméstica (Aguiar, 2009; Monteiro, 2014).

A Senhora V ressalta a interferência popular na cena do bar em que o Senhor V rasgou sua roupa: 'Falei: 'Me solta! Me solta!' O pessoal do bar: 'Vamos chamar a polícia. Vamos chamar a polícia.' [...] Foi embora. Porque o pessoal lá: 'Vou chamar a polícia'. Ele pegou e foi embora". Ela parece reconhecer que tal posicionamento resultou em uma intervenção que gerou limite e proteção.

A interferência da Justiça, que resultou na prisão do Senhor V, também foi avaliada positivamente:

\footnotetext{
Se não tivesse dado essa parada, as coisas não iam terminar muito bem, porque ele estava tão transtornado. [...] Ou ele ia se matar, porque ele falava o tempo inteiro que ia se matar. Era se matar e me matar. [...] Porque estava assim transtornado, algo de pior ia acontecer. [...] Essa parada da prisão, não sei... que fez ele refletir, ver que não era daquele jeito.
}

A Senhora V fala das consequências da prisão do Senhor V para ela: "Nos primeiros dias, eu senti aquele alívio. Alívio de quê? De não estar sendo perseguida. De onde eu ir, saber que nada pode acontecer". Ela fala também das consequências para ele: "Essa parada, por mais dolorosa que tenha sido... Ele fala que foram os piores dias da vida dele. Eu acredito mesmo, porque ninguém quer perder sua liberdade. [...] Eu sei que foi difícil, mas ele refletiu. Tudo que estava acontecendo, saiu outra pessoa”. 
A interposição da ameaça da Justiça por populares inibiu a continuidade da situação violenta. A prisão, em uma circunstância extrema, após violência grave, provocou alívio na Senhora $\mathrm{V}$, que, apesar de achar o limite imposto pela prisão motivo de sofrimento, percebeu a contribuição na mudança no agressor. Essa mudança foi atribuída à oportunidade de reflexão que o contexto propiciou. A Justiça que dá limite, mesmo que interpretada como disruptiva ou excessiva, pareceu oferecer algo de positivo ao casal V.

A Senhora V falou sobre a maneira como a Justiça atuou e, consequentemente, sobre como ela se posicionou diante do trabalho:

eu não gostava muito, porque eu achava as psicólogas de lá... Quando eu ia para as audiências, eu acho que elas tentam induzir. Eu sei que elas trabalham com isso o tempo inteiro. Elas entendem muito mais do que eu, que no caso sou a vítima. Nesse processo eu sou a vítima. Mas de uma forma que elas querem induzir que você fale. [...] Eu vi que elas queriam: "Vamos condenar, condenar. O caso dele é de condenação, condenação". [...] Elas não achavam que depois de tudo que aconteceu a gente pudesse ter uma vida mais ou menos normal. Elas achavam que já era um caso que não tinha mais jeito.

A senhora V revelou sua opinião sobre outro ator judicial importante:

o juiz lá, eu vejo que ele não é só o que está ali escrito. Ele é muito de saber a história, o que está acontecendo. [...] Quando o advogado pediu para ele ser solto, ele me ligou e falou: "Senhora $V$, o advogado está querendo soltar. Como não tem nada provado ainda... Você tem medo que ele saia e mate você?" Falei: "Não". [...] Perguntou se a gente saía, se eu já tinha tido alguma visita íntima [...] Ele: "Quando ele sair, vocês vão voltar?" Eu falei: "Não sei, doutor, não vou mentir para o senhor, dizer que sim ou que não". [...] Ele quer saber da história, de tudo que está acontecendo. [...] Não foi uma vez só que ele me ligou. Foram umas duas vezes, querendo saber da minha situação, o que que eu achava, se eu tinha medo.

A Senhora V esclarece a posição da família dele perante a Justiça: "Eles não aceitaram muito isso. Até hoje a gente não tem um bom relacionamento. [...] Eles 
dizem: 'Ah, mas ela colocou ele na cadeia. Agora, estão juntos'. Ela relata também a própria posição: “Aí eu ficava pensando: ‘Meu Deus, será que eu fiz certo?’ Eu falei: 'Não era nem questão de fazer certo. Era uma coisa que estava acontecendo e que eu precisava me proteger. Eu tive que acionar a Justiça, porque falar não estava adiantando"”.

As indicações da responsabilização da Senhora V pelo andamento do processo judicial parecem incomodá-la, apesar de ela entender que a Justiça age assim com outros também. A culpabilização da família de origem do Senhor V é percebida como gesto de incompreensão por parte da Senhora V. Ela também apresenta algo desses incômodos pela culpa internalizada, como se nota na dúvida se fez certo ou errado ao denunciar.

Atores da Justiça envolvidos a responsabilizam pelas condições da conjugalidade violenta, pela violência que o homem perpetrou e pela consequência que ele teve que sofrer. Tudo isso, somado às próprias representações internalizadas, a coloca em um lugar de culpa. O fato é que a mulher vítima de violência doméstica procura na Justiça um limite representado pela interrupção da violência ou continência do agressor. Além disso, busca operacionalizar uma transformação do parceiro e do relacionamento (Angelim, 2009; Guimarães, 2011).

A Justiça é percebida como um aparato paradoxal — ao mesmo tempo que gera a possibilidade de cuidado e proteção, pressiona a vítima por meio de tentativas de convencimento, que indicam que o julgamento da situação, implicitamente, é responsabilidade dela. A pressão é exercida em uma direção específica: a condenação da relação conjugal e do réu processual. Por outro lado, a Justiça, na figura do juiz, também se apresenta como uma instituição que quer tomar decisões com base nas particularidades da experiência e das necessidades de proteção e segurança da Senhora V e de sua relação com o Senhor V. 
O juiz, por sua vez, deixa clara a intenção de protegê-la. Esse posicionamento a deixa confortável para responder o que deseja e se sentir menos incomodada. Escutar o que as mulheres vítimas de violência conjugal esperam da Justiça quando pedem ajuda é de fato necessário. A complexa construção da autonomia máxima possível da mulher vítima não deve eximir o Estado e seus atores dos seus deveres e posicionamentos institucionais (Angelim, 2009; Angelim \& Diniz, 2009; Guimarães, 2011).

\section{Casal K}

A Senhora $\mathrm{K}$ relatou recorrer à Justiça nas situações de violência física perpetrada pela mãe do Senhor K: "Tem dois boletins de ocorrência contra ela", derivados da agressão na praça e dos puxões de cabelo na casa da vítima. Após os puxões de cabelo, a Senhora K ameaçou contar toda a situação à polícia caso a mãe do Senhor K não fosse embora. Já quando a tia da Senhora K ouviu as ameaças de morte, elas tomaram a decisão: "Aí minha tia foi comigo e a gente foi na delegacia".

A Justiça é percebida como um limitador dinâmico e relacional à violência. Recorrer a essa instituição é indicado nas situações de ameaça ou de denúncia. A ameaça de recorrer à Justiça, na situação de violência cometida pela sogra, tinha o interesse de promover o afastamento da agressora. A ameaça não pareceu contê-la, de modo que a Senhora K e sua tia acharam conveniente denunciar, possivelmente na expectativa de outro tipo de continência ou proteção.

A correção dos excessos da violência não pode ser o limite do trabalho da sociedade ou da Justiça nas situações de violência contra a mulher. É importante promover a desestabilização da própria ordem de status que envolve a feminização dos corpos por meio da submissão e violência (Segato, 2010). Os status que envolvem a submissão no contexto patriarcal definem a normatividade de gênero, de geração, de 
classe etc. A Senhora K demandou da Justiça a mediação de uma relação pautada por representações de desigualdade hierarquicamente situadas entre mulheres.

A Senhora $\mathrm{K}$ relatou que, depois da cena de espancamento a que foi submetida pelo Senhor K, pegou a criança $K$ e foi para a casa da sua mãe. Ela afirmou que já estava machucada. Nesse contexto sua mãe ligou para o seu pai, [...] que a levou na delegacia, momento em que fez o boletim de ocorrência. De lá, a Senhora $\mathrm{K}$ foi encaminhada para o Instituto de Medicina Legal - IML, órgão vinculado à Polícia Civil do Distrito Federal. "Na delegacia, perguntaram dele. Eu falei que ele estava em casa. 'Não, então a gente vai lá'. Eu dei a chave para o meu pai. Eles foram lá. Pegaram, ele estava dormindo. Igual eu falei, dormindo no sofá.” O Senhor K relata sua versão do que aconteceu:

\begin{abstract}
eu lembro de ter visto ela saindo com a criança $K$, fechando a porta. [...] Deitei de novo no sofá. Eu nesse sentido, de que eu achei que era um sonho. Já estava dormindo de novo. Passou um pouco, os policiais invadiram minha casa, sem minha autorização. [...] Alguém deu a chave para o pai dela e ele entrou lá com a polícia. Entrou dois agentes e o pai dela na minha casa. Não sabia nem o que falar, o que falaram e tal. Não sabia nem o que estava acontecendo. "Por que que vocês estão aqui? O que que vocês estão fazendo aqui? " [...] Não, até então eu não sabia do que estava acontecendo. Eu não sabia mesmo.
\end{abstract}

Nesse momento do relato, o entrevistador perguntou se o Senhor K sabia por que tinha sido preso: "Não. Até então, não. E ninguém falou nada comigo. Ninguém falou nada comigo. Me prenderam: 'Pega suas coisas aí'. Eu: 'Por quê? Por quê?' Não me falaram nada. Me colocaram no camburão. Me colocaram na cela, só de cueca”.

O Senhor K é capturado pelos agentes da Justiça, colocado em um camburão, levado à delegacia, despido e jogado em uma cela, sem sequer saber o que tinha acontecido para ser carregado e quais eram as acusações. Ninguém explicou. A Justiça é 
percebida e relatada por ele como muito intrusiva. Os policiais entraram sem autorização em sua casa e o jogaram na cela despido, segundo seu relato.

O Senhor K conta suas impressões sobre a cena de espancamento: "Eu acho que esse assunto foi um grande incidente na minha vida... total. Depois que eu fui tentar entender a situação, foi mais uma reação do que uma ação, de fato. Inclusive, foi o que eu disse diretamente para o juiz". A Senhora K aponta falas do Senhor K sobre sua prisão: "Ah, você tem a sua família. Você teve o amparo". Ele acha que o que ele sofreu foi muito pior. Ele acha que eu apanhei na hora e depois ficou tudo bem”.

Para o Senhor K, houve desproporcionalidade da Justiça ao lidar com o espancamento:

fui preso na mesma hora. Não tive tempo nem de revidar, para explicar nada, falar nada. [...] Nossa, virou o caos a minha vida, virou o inferno literalmente. Uma coisa que acontece aqui. Parece que já tinha uma avalanche pronta, já. A propensão para o mal, acho que é uma coisa extraordinária. [...] Acho que não é nem uma bola de neve, porque a bola de neve é uma coisa que vai acumulando, é uma coisa que já vem pronta. [...] No nosso caso, a gente nunca teve atrito, nunca teve discussão, nunca teve nada assim. Eram só coisas bestas, banais, do dia a dia. Do nada explode uma situação, vira um inferno total, cara.

Segundo a Senhora K, o Senhor K “[...] acha que ele é vítima, no sentido de que ele não merecia estar lá. Para ele, ele não merecia. Foi algo injusto, algo totalmente de graça. Ele não merecia estar lá na prisão. Que o algo que aconteceu foi pequeno”. Os eufemismos e as distorções, marcados pelo uso das palavras "incidente", "reação", "situação" e "algo pequeno", aparecem nos discursos tanto da Senhora K quanto do Senhor K sobre a Justiça. As estratégias que envolvem o redimensionamento dos sentidos da violência conjugal são frequentemente descritas nos estudos e envolvem anestesias, justificativas, minimização, negligência e mesmo negação (Diniz, 2011, 2013; Diniz \& Pondaag, 2004, 2006; Pondaag, 2009; Ravazzola, 2005). A violência do 
casal fica evidenciada no discurso como se fosse algo pequeno, pouco danosa ou mesmo não reconhecida.

Ao ser perguntado sobre ações da Justiça, o Senhor K disse: "Eu fiquei preso três dias. Saí e ela entrou com uma ação de [...] medida protetiva. Contato nenhum, telefone, Whatsapp, e-mail, nada. Nada, nada. Cumpri os dois meses. Ela foi lá e cancelou a medida". A Senhora K, por sua vez, relatou suas impressões sobre a postura do Senhor K:

ele desconsidera um pouco [grifo nosso para pontuar a minimização] o ato violento que ele fez contra mim. Ele acha que ele sofria muito mais na prisão do que eu com o ato. Ele já falou coisas insinuando que eu fui a responsável por ele estar preso. [...] "Você não estava nem aí para mim quando fez isso. [...] Você não pensou quando você foi lá. É assim que você diz que me ama? É assim que você diz que me amava, fazendo isso? [...] Você não pensou em mim quando foi lá na delegacia”. Coisas assim, ele já disse várias vezes.

O reposicionamento das posições subjetivas inverte algoz e vítima, apontando e confundindo a aliança entre vítima e Justiça em desfavor do agressor. A Senhora K se torna um agente da Justiça no discurso do Senhor K. Para a Justiça, as posições de algoz (homem, ativo, forte) e vítima (mulher, passiva, fraca) se reorganizam em réu (homem, passivo, fraco) e denunciante (mulher, ativa, forte) (Andrade, 2005; Campos \& Carvalho, 2006). No relacionamento do casal K, esse reposicionamento corrobora a postura de não reconhecer a violência em sua gravidade e consequências e culpabilizar a mulher pelos conflitos conjugais que tangenciam a situação de violência.

\section{Considerações finais}

Esta pesquisa relatou dois estudos de caso referentes à confrontação de situações de violência conjugal, sua denúncia e inserção no sistema de Justiça, assim como os encaminhamentos resultantes dessa ação. Foram problematizadas as construções e 
significações das dinâmicas da violência conjugal com base no ponto de vista da mulher agredida, do agressor e dos profissionais do sistema de Justiça. A intenção foi compreender de que forma as questões de gênero e poder atravessam essas relações marcadas pela violência. Categorias que envolviam os cônjuges, a família e a Justiça compuseram essa análise para aproximar os aspectos externos que influenciam a dinâmica relacional e os aspectos internos da conjugalidade violenta.

A violência conjugal — mesmo aquela que parece surgir espontaneamente de um conflito relacional — é atravessada por padrões tradicionais de gênero mantidos e reforçados por estruturas patriarcais disseminadas e estruturantes das mais diversas práticas e representações da sociedade. Ficou evidente que a compreensão da violência deve levar em consideração sua complexidade e dinamicidade, pois as construções que engendram as cenas violentas nos relacionamentos são estruturais e permeiam todo um contexto sociocultural. Em um dos casos estudados, do casal K, apesar de a cena de violência mais grave ter sido considerada situacional, é perceptível como o casal carrega perspectivas de suas famílias de origem cuja dinâmica relacional deixa clara a presença de práticas violentas. Estas agravam a situação e contribuem para a vulnerabilidade instaurada pela violência conjugal.

A vida conjugal ainda é marcada pela ordem do privado. Existe uma compreensão cultural de que a conjugalidade não deve sofrer interferência externa. No entanto, a interferência familiar foi relatada em várias situações extremas como protetiva e equalizadora de poder. Por exemplo, na situação em que o Senhor V tentou privar a Senhora $\mathrm{V}$ de contato, esta poderia ter sofrido agressão mais grave se os familiares dela não chegassem à casa a tempo de intermediar a situação. Por outro lado, a ausência de suporte da família do Senhor V aumenta sua vulnerabilidade.

As interferências familiares não são necessariamente positivas, negativas ou equalizadoras de poder. As díades Senhor K e mãe do Senhor K e Senhora K e pai da 
Senhora K se apresentaram ou foram convocadas a interferir na conjugalidade de tal forma que os dois sogros perpetraram violências graves contra os cônjuges dos respectivos filhos. O relacionamento competitivo entre a Senhora $\mathrm{K}$ e a mãe do Senhor K promoveu distanciamento e conflitos conjugais. A tentativa de proteção e/ou vingança do pai da senhora $\mathrm{K}$ gerou rompimento com o senhor $\mathrm{K}$ e conflitos conjugais.

A violência é amplamente influenciada por crenças, valores, mitos e práticas, rituais ou não, que se situam nas famílias de origem dos cônjuges. Algumas das bases conflitivas que promovem circunstâncias de violência podem ser instigadas pela dificuldade dos cônjuges, representantes de suas famílias de origem, em negociar as diferenças. Uma base de conflitos indicada no estudo é a submissão feminina ao homem/masculino; de geração nova e dominação masculina e/ou de geração velha. Outra base de conflitos é a diferença das considerações sobre a divisão e a execução de trabalhos domésticos, que passa pelas concepções tradicionais de gênero.

O Estado, por sua vez, na figura da Justiça que dá limite, mostrou seu potencial de interromper situações extremas de violência que poderiam levar à morte, como no caso do casal $\mathrm{V}$, e de provocar mudanças. O Estado não pode se eximir de tomar decisões e interferir em relações de desigualdade e violência, mesmo que estas se deem no ambiente doméstico, onde há maior dificuldade de acesso. Além disso, a pesquisa mostrou ser muito importante para o Estado considerar as particularidades de cada caso, escutar as necessidades das vítimas e evitar violações ao agressor.

A Senhora $V$ se encontra em uma posição difícil perante a Justiça. As representações que a responsabilizam, com culpabilização ou não, pelas decisões e pelos protocolos judiciais são vistas como incômodo. Por outro lado, quando foram consideradas suas particularidades e a Justiça indicou a intenção de protegê-la e de não se eximir da função da decisão, ela se mostrou mais confiante na interação com a 
Justiça. Escutar as partes interessadas não significa delegar às mulheres a responsabilidade pelas ações do Estado.

A Justiça funcionou como um agente que limitou a incidência, a reincidência e a escalada da violência. Uma boa parte do mérito está, na verdade, com as mulheres que acreditaram na instituição e denunciaram as violências algumas vezes antes mesmo de as cenas mais graves ocorrerem. Parece que o que foi buscado nesse contexto foi o limite, ou seja, um aparato de Justiça que pudesse indicar balizas e continência para as agressões.

As denúncias apareceram nos dois estudos de caso como fatores de proteção. $\mathrm{O}$ mérito da Justiça é ter tomado providências diversas, mas voltadas para as demandas. A Justiça que aparentou ser mais punitiva, como no caso do Senhor K, revela que a cadeia de violência não termina quando se transforma o dominador em submetido. Escutar a demanda da vítima não significa perpetrar violações contra o agressor. De forma perversa, o Senhor K se utiliza da situação em que teve seus direitos violados para minimizar a violência e distorcer o papel da companheira na interferência que ela teve sobre a decisão judicial.

Estudos sobre a forma como as instituições - o casamento, a família e/ou os aparatos da segurança pública e Justiça — influenciam a conjugalidade violenta são extremamente necessários, pois podem contribuir para a construção de melhores formas de atuar com os casais em situação de violência conjugal. É fundamental, portanto, a realização de mais estudos que tenham como foco compreender os mecanismos de construção das situações de violência conjugal.

A adesão aos papéis tradicionais de gênero permeia todas as instituições sociais, entre elas o casamento, a família, o sistema de Justiça, as instituições que oferecem serviços de intervenção e prevenção. A desestabilização das hierarquias rígidas é importante para a diminuição da violência de gênero como um todo, inclusive a 
conjugal. Além disso, são necessários mais estudos que se dediquem a compreender a interação das mulheres e dos homens com a Justiça. Esses estudos são importantes devido ao fato de as legislações concernentes constituírem avanços muito recentes e de suas aplicações ainda serem muito diversas, frequentemente sem correspondência com os avanços da lei. 


\section{ARTIGO 4 \\ A VIOLÊNCIA SEXUAL NA CONJUGALIDADE: GÊNERO E PODER NOS \\ ROTEIROS SEXUAIS E RITUAIS CONJUGAIS}

Resumo: As relações entre as construções e significações afetivo-sexuais e as dinâmicas da violência conjugal precisam ser compreendidas. Este artigo apresenta parte dos dados de dois estudos de caso cujo objetivo foi identificar de que forma as práticas sexuais e as questões de gênero e poder atravessam relações marcadas pela presença de controle e violência. Os casais participantes vivenciaram violência conjugal com denúncia judicializada e passaram por atendimento psicossocial. Foram realizadas entrevistas de construção de genogramas e entrevistas semiestruturadas, e foi aplicado o instrumento CTS-2. Os dados passaram por análise de conteúdo. Os resultados apontam que a violência sexual parece menos comunicada e inteligível que outras formas de violência conjugal. $\mathrm{O}(\mathrm{a})$ agressor(a) age intencionalmente e em contextos de poder e controle perpassados por dupla moral sexual.

Abstract: This article presents part of the data from two case studies. The aim was to investigate how sexual-affective constructions and meanings relate to intimate partner violence dynamics, in order to understand how sexual practices and gender issues permeate such relationships. The participants were two couples that experienced intimate partner violence followed by judicial complaint. They were referred to psychosocial treatment. The CTS-2 test, semi-structured interviews and interviews based on the construction of genograms were applied. Content analysis was used to build the case studies. The results show that sexual violence is even less communicated and intelligible than other forms of intimate partner violence. The aggressor acts intentionally in contexts of power and control permeated by a twofold sexual morality. 


\section{Introdução}

Pesquisas que tratam da violência sexual perpetrada por parceiro íntimo indicam que esse tipo de violência é extremamente frequente — um estudo abrangente de base populacional realizado no Brasil indica a incidência de 8,6\%. Os critérios adotados para considerar a presença de violência sexual cometida por parceiro íntimo foram: "1) 'Foi forçado(a) fisicamente a manter relações sexuais quando você não queria?'; 2) 'Teve relação sexual porque estava com medo do que ele/a pudesse fazer?' e 3) 'Foi forçado(a) a uma prática sexual degradante ou humilhante?"” (Schraiber, Oliveira \& Junior, 2008). Esses critérios revelam a presença de uso da força, medo, coerção, humilhação e imposição da vontade e poder no ato sexual.

Outro estudo, que caracterizou a violência sexual perpetrada por parceiro íntimo de forma similar, foi realizado com mulheres na faixa etária entre 15 a 49 anos. Os resultados indicaram a incidência de $10,1 \%$ de violência sexual em São Paulo e 14,3\% em 15 municípios da Zona da Mata Pernambucana (Schraiber et al., 2007). Um estudo realizado em unidade de saúde em Porto Alegre apontou a incidência de $9 \%$ de violência sexual conjugal, a qual foi caracterizada de forma similar aos estudos anteriores (Kronbauer \& Meneghel, 2005).

Pesquisa realizada com jovens de 18 a 24 anos apontou que a coerção sexual foi de $10,9 \%$ em Porto Alegre, $13,1 \%$ no Rio de Janeiro e 16,7\% em Salvador. Na mesma pesquisa, quando comparados mulheres e homens, a incidência foi de 15,3\%, 15,4\% e $19,1 \%$ entre as mulheres e $6,3 \%, 10,7 \%$ e $14,1 \%$ entre os homens. A coerção sexual foi considerada, em tal pesquisa, como: violência física, ameaça de violência física, outro tipo de violência e muita insistência. Entre aqueles que sofreram coerção sexual, o agente foi o parceiro ou ex-parceiro amoroso em 53,6\% dos casos entre as mulheres e 33,3\% dos casos entre os homens (Moraes, Cabral \& Heilborn, 2006). 
Uma questão presente nos estudos relacionados à violência sexual conjugal chama a atenção: há forte tendência ao sub-registro e à subnotificação da violência. Fica a indagação se tal tendência se deve fato de as pesquisas terem sido realizadas, em sua maioria, nos âmbitos institucionais, ou seja, nos contextos da saúde, segurança pública e Justiça. É importante ressaltar também que esses estudos evidenciam processos de relativização da violência, em razão das construções culturais que representam o sexo como obrigação das mulheres. Há maior prevalência e maior gravidade da violência contra as mulheres (Dantas-Berger \& Giffin, 2005; Moraes et al., 2006; Schraiber et al., 2007, 2008).

A violência sexual, ao ser incluída e referenciada na Lei Maria da Penha - a Lei 11.340/2006 —, é redimensionada como violação de direitos. Essa estruturação do conceito é importante, pois passa a considerar os direitos sexuais e reprodutivos das mulheres, que podem ser objeto de diversas práticas protetivas e assistenciais. No âmbito da sexualidade, violência é também, por exemplo, forçar práticas abortivas, obrigar ao casamento, transmitir doenças sexualmente transmissíveis, expor imagens íntimas e praticar pornografia. A violência sexual é assim tipificada na lei:

\footnotetext{
a violência sexual, entendida como qualquer conduta que a constranja a presenciar, a manter ou a participar de relação sexual não desejada, mediante intimidação, ameaça, coação ou uso da força; que a induza a comercializar ou a utilizar, de qualquer modo, a sua sexualidade, que a impeça de usar qualquer método contraceptivo ou que a force ao matrimônio, à gravidez, ao aborto ou à prostituição, mediante coação, chantagem, suborno ou manipulação; ou que limite ou anule o exercício de seus direitos sexuais e reprodutivos (Brasil, 2006, p. 14).
}

Feix (2011) aponta que as Conferências de Cairo, Copenhagen e Pequim resultaram na construção de legislação internacional referente aos direitos sexuais e reprodutivos das mulheres. Tais direitos abrangem os seguintes conteúdos normativos: 
Direitos Sexuais: 1) O direito de explorar a própria sexualidade sem medo, vergonha, culpa, falsas crenças e outros impedimentos à livre expressão dos próprios desejos e orientação sexual. 2) O direito a viver a própria sexualidade sem violência, discriminação, nem coerção, dentro de um marco de relações baseadas na igualdade, respeito e justiça. 3) Pleno respeito à integridade física do corpo. 5) O direito a escolher os/as próprias companheiras/os sexuais sem discriminação. 4) $\mathrm{O}$ direito a escolher ser sexualmente ativo/a, a não ser-lo, incluído o direito a ter sexo que seja consensual. 5) O direito a expressar a sexualidade independentemente da reprodução. 6) O direito a praticar sexo seguro e com prevenção de gravidez não desejada, bem como de doenças sexualmente transmissíveis, incluindo HIV. Direitos Reprodutivos: 1) decidir livre e responsavelmente o número de filhos e intervalo entre eles; 2) controlar seus próprios corpos; 3) ter sexo consensuado, sem violência nem coerção; e 4) contrair o casamento com o consentimento pleno e livre de ambas as partes. (Feix, 2011, p. 206)

O estupro conjugal, por sua vez, envolve um conjunto de práticas inseridas no conceito de violência sexual. No estupro, o ato sexual violento se dá por meio de força ou ameaça, entre outros aspectos intimidadores ou coercitivos, de modo que a vítima é constrangida a realizar a prática sexual específica por medo ou outra vulnerabilidade que implique a impossibilidade ou ilegitimidade do consentimento.

O estupro conjugal é o estupro cometido por parceiro íntimo. Muitas vezes, o acordo conjugal compreendido como o término do relacionamento não coincide com as experiências psíquicas ou dinâmicas de desligamento do contexto relacional. Por conta dessa dinâmica, o estupro praticado por ex-parceiros é considerado estupro conjugal neste artigo.

A coerção sexual também é um conceito relevante neste trabalho, pois é um pouco mais abrangente que o estupro. Esse conceito leva em consideração elementos como a insistência — pressão verbal que não necessariamente contenha ameaça; o sexo consentido sem desejo, mediante mentiras, manipulações e falsas promessas ou para evitar conflitos; e o estímulo ao uso de álcool e outras drogas que 
possam alterar e/ou limitar a consciência (Carmona, 2011; Cordeiro, 2008; Cordeiro, Heilborn, Cabral \& Moraes , 2009; Lottes \& Weinberg, 1997).

A violência sexual e, de modo especial, a violência sexual praticada por parceiro íntimo nos colocam diante da invisibilidade da violência, decorrente de sua relativização e banalização (Dantas-Berger \& Giffin, 2005; Kronbauer \& Meneghel, 2005). Uma postura relativista em relação à violência pode intensificar sua invisibilidade e corroborar a violência sexual conjugal como prática própria ao contexto doméstico, com interferência externa limitada.

A adoção de tal postura estimula as relações hierárquicas no contexto das conjugalidades violentas — produz um processo de retroalimentação que deixa pouca potencialidade e espaço para a mudança. O agressor faz algo similar. Ele controla a rede social da vítima, reduzindo-a o máximo possível, e explora elementos relacionais que enrijecem as posições subjetivas dele e da mulher, o que naturaliza cada vez mais a violência.

Este artigo não pretende relativizar a violência, mas sim apontar e problematizar a complexidade das situações em que ocorre a violência conjugal. A violência sexual conjugal se manifesta em um contexto intrapsíquico, interpessoal, cultural e histórico particular. As significações atribuídas às práticas são determinantes para a vivência e percepção da experiência violenta, seja como agressor, seja como vítima. As práticas sexuais não podem ser descoladas das estruturas narrativas que compõem a dinâmica relacional em uma dada cultura e momento histórico-social. É preciso levar em conta as interpretações de cada ator acerca dos processos dos quais participa.

Um ponto central para contextualizar a noção de violência sexual é a presença ou não do consentimento. Ele parece um contraponto à noção de estupro, em que a vítima não concorda com o que acontece ou é forçada a aceitar. Existem, porém, 
muitas situações em que o sexo consentido é um sexo indesejado. Infelizmente, esse processo se faz presente no contexto das conjugalidades.

Estudo realizado por Muehlenhard e Peterson (2005) propõe modelo que explora descontinuidades entre sexo desejado e indesejado. Os fatores propostos pelos autores para a avaliação de experiências no contexto da sexualidade são:

- múltiplas dimensões nas quais o sexo pode ser, ao mesmo tempo, desejado e indesejado. Alguns exemplos dessas dimensões são: excitação sexual, atração, medo de danos à imagem, desejo de melhorar a imagem, medo de gravidez e medo de contrair DSTs;

- distinção entre desejar a atividade sexual e desejar suas consequências, como promover intimidade, satisfazer as necessidades do parceiro, evitar tensões no relacionamento e engravidar;

- diferenciação entre sexo desejado e sexo consentido. Alguns motivos para consentir podem envolver ter medo de violência, evitar conflitos e perceber a prática sexual como obrigação;

- $\quad$ sexo não consentido desejado. Pode ser muito conflitiva a elaboração de uma prática sexual como estupro.

É importante que não se confunda uma discussão complexa sobre as múltiplas dimensões dos roteiros sexuais intrapsíquicos, interpessoais e presentes nos cenários culturais com o mito de que as mulheres gostam de ser estupradas. $\mathrm{O}$ estupro pode ser e frequentemente é experienciado e vivido com culpa, como se a vítima tivesse alguma responsabilidade ou tivesse causado a situação da violência sexual.

Mesmo que algumas dimensões e significações da experiência sexual possam indicar à vítima e ao autor que ela desejou o sexo - tais como intumescimentos corporais, lubrificação ou expressões faciais —, a caracterização do estupro passa pelo não consentimento. A hipótese de Muehlenhard e Peterson (2005) é de que diferenciar 
consentir e desejar, nesse caso, pode esclarecer a confusão e culpabilização que a vítima sofre.

O sexo com consentimento envolve complexidades que vão além de práticas sexuais de poder explícito, como nas relações com alguém que está alterado e é considerado incapaz de consentir ou forçado a consentir. Em casais em que a situação de violência sexual conjugal é regular, o desejo da mulher de evitar consequências negativas implica relações consentidas pautadas em práticas sexuais coercitivas. Ao mesmo tempo, a conjugalidade violenta pode envolver relações sexuais desejadas e com estruturas narrativas que envolvem reconciliação, prazer mútuo, nova possibilidade de união etc.

A percepção do sexo como obrigação da conjugalidade pode garantir consentimento em cenas violentas. Práticas sexuais humilhantes, sexo que envolve danos físicos e dificuldade de negociação podem estar entre as formas de violência sexual vivenciadas na conjugalidade. O consentimento, por si só, é insuficiente para qualificar a experiência como livre de violência sexual.

Outro aspecto importante para a compreensão da violência sexual conjugal é a noção de sedução. Alguns tipos de sedução podem ser atribuídos diferentemente aos dois sexos na conjugalidade. $\mathrm{O}$ homem parece vincular a sedução a um processo que reverte a falta de interesse ou vontade da mulher - um "consentimento", nesse contexto, forçado. Caso seja seduzida, a mulher fica, em muitos casos, "responsável" pela resposta positiva em relação às práticas sexuais. Assim, a masculinidade é continente de uma forma de sedução ativa, enquanto a feminilidade é associada a forma de sedução passiva.

Em uma pesquisa sobre a negociação da sexualidade entre membros de casais, realizada no Chile, Carmona (2011, p. 813) relata que "as entrevistadas descrevem que, para evitar o conflito, não falam, mas sim cedem às demandas dos homens. Além disso, 
os homens não negociam, já que ou se incomodam com suas parceiras, o que pode gerar discussões, ou seduzem, como uma forma de evitar conflitos". ${ }^{14}$

A sedução realizada pelo homem pode constar nas práticas sexuais como uma não negociação, uma forma de realizar uma transição entre a falta de interesse ou desejo da mulher, de fazê-la mudar de ideia e aceitar o ato sexual. Na conjugalidade violenta, pode-se supor que a sedução é feita ativamente pelo homem, em muitos casos, independentemente de interesse ou desejo da mulher. Algo muito similar a essa representação de sedução masculina é descrito nas experiências dos casais violentos e dos condenados por estupro. Diniz (2013, p. 204) afirma que,

nas relações violentas, é comum a mulher ser vista como objeto sexual. A relação tende a ser pautada em prescrições tradicionais: o sexo é uma obrigação das mulheres casadas, que têm que servir e estar dispostas a satisfazer as necessidades e os caprichos sexuais dos maridos. Suas próprias necessidades raramente contam. Manifestações de violência sexual agravam esse contexto.

Machado (1998, p. 237), em reflexão sobre os condenados por estupro, diz que "as narrativas dos apenados fazem referência a uma expectativa da moralidade social vigente, que atribui ao homem a transformação do não inicial da mulher em sim. Se o não continua é porque a sua natureza viril, sua capacidade de conquista, é a que está em jogo".

Fica evidente a relação entre a objetificação sexual da mulher e o estupro, dentro e fora do contexto da conjugalidade violenta. Esse processo gera jogos de sedução e manipulação perversos, bem diferentes daqueles comuns e saudáveis entre casais que não vivem em situação de controle, manipulação e violência. Apesar da distinção entre essas vivências — violentas e não violentas —, é importante mencionar que elas estão

\footnotetext{
14 Tradução livre realizada pelo autor.
} 
associadas em termos de seus operadores hierárquicos que normatizam as relações de poder em uma cultura patriarcal.

A sedução que parece extremamente relacionada à negociação, ou seja, um contraponto à coerção sexual, é retomada em vários contextos simplesmente como um processo para transformar não em sim. O estupro conjugal é a transformação do não em sim pela força. A coerção sexual pode ser a transformação do não em sim por insistência. Significados e práticas sexuais coercitivas, por força ou não, podem ser interpretados e organizados nas narrativas como um fim alcançado, ou seja, a sedução para obter do outro algo que ele não quer dar.

Estudar a sexualidade de casais em situação de violência requer contextualizar as estruturas narrativas subjacentes às condutas sexuais. As significações e práticas sexuais se dão em uma cena sexual com roteiros sexuais intrapsíquicos, interpessoais e socioculturais (Gagnon, 2006; Gagnon \& Simon, 2005). Os atores que desempenham seus papéis não precisam que a violência seja relativizada ou banalizada para que possamos analisá-la ou compreendê-la em contexto.

\section{Método}

Este artigo apresenta dados de dois estudos de caso realizados com dois casais em situação de violência conjugal. $O$ objetivo geral da pesquisa foi identificar as construções e significações afetivo-sexuais que permeiam o exercício da sexualidade e analisar seu impacto na dinâmica de casais em situação de violência conjugal.

A investigação da dinâmica relacional foi feita com o uso de roteiros sexuais, rituais conjugais e genogramas sexuais para identificar as construções pessoais, geracionais e sociais que resultam em significações para o exercício da sexualidade dos casais participantes. Investigou-se também como as questões de gênero atravessam as experiências identitárias, relacionais e afetivo-sexuais dos casais. 
O material coletado foi analisado com a intenção de identificarmos as relações existentes entre as construções e significações afetivo-sexuais com as dinâmicas da violência conjugal. A intenção foi compreender de que forma as práticas sexuais e as questões de gênero e poder atravessam essas dinâmicas.

Entre os recursos utilizados para a construção dos estudos de caso, estão entrevistas que contemplam temas associados à sexualidade no contexto da violência. Essas entrevistas foram construídas com base nos referenciais dos roteiros sexuais, dos rituais conjugais e do genograma sexual, que conta com roteiro próprio. Além das entrevistas, foram utilizados dados de um instrumento que contém uma escala de coerção sexual. Além de qualitativa, a pesquisa é exploratória, pois diferentes recursos são conectados para uma finalidade: produzir conhecimento sobre fenômenos humanos complexos, multideterminados e dinâmicos.

\section{Participantes}

Os participantes da pesquisa foram dois casais que vivenciaram situações de violência conjugal. Os casais foram selecionados por conveniência no Programa de Assistência Multidisciplinar a Vítimas de Violência - Pró-Vítima do Distrito Federal, onde trabalha o pesquisador. Os critérios para inclusão dos participantes na pesquisa foram: formar casal heterossexual; ter vínculo conjugal formal ou informal; residir na mesma moradia; conviver maritalmente há pelo menos um ano; ter pelo menos uma denúncia formal de situação de violência conjugal; ser maior de 18 anos. Além desses critérios, houve coincidência no fato de ambos os casais terem um filho, de morarem no domicílio apenas casal e filho; e de todos os participantes terem empregos formais. 


\section{Procedimentos éticos e instrumentos utilizados para coleta de dados}

O estudo obedeceu aos requisitos éticos para a condução de pesquisa com seres humanos. O projeto foi submetido à Plataforma Brasil e aprovado pelo Comitê de Ética em Pesquisa do Instituto de Ciências Humanas (CEP-IH) da Universidade de Brasília. Todos os participantes leram e assinaram o Termo de Consentimento Livre e Esclarecido (TCLE).

Foi aplicado um questionário sociodemográfico para cada membro dos dois casais (Anexo 1-A). Além disso, foram realizadas: uma entrevista com cada casal para construção de seu genograma (Anexo 1-B); duas entrevistas com cada casal para construção de seu genograma sexual, uma para a família de cada membro (Anexo 1-C); uma entrevista com cada membro do casal, com questões sobre casamento, violência e sexualidade (Anexo 1-D); uma entrevista de fechamento e avaliação da coleta de dados com o casal e aplicação do CTS-2 (Anexos 1-E e 1-F). ${ }^{15}$ O instrumento CTS-2, usado para identificar a violência entre casais, foi aplicado nos casos estudados por conter dimensão específica sobre a coerção sexual.

O genograma sexual é o processo de construção de uma imagem gráfica para alcançar informações sobre os relacionamentos e padrões familiares plurigeracionais, ou seja, no tempo e no espaço (McGoldrick \& Gerson., 1995; McGoldrick, Gerson \& Petry, 2012). Entre os genogramas mais específicos, as entrevistas para os genogramas sexuais têm como foco o aprendizado da sexualidade, bem como as transmissões transgeracionais e culturais da atitude em relação à expressão sexual e a questões de poder, intimidade e afeto (Belous, Timm, Chee \& Whitehead, 2012; McGoldrick, Loonan \& Wohlsifer, 2011; Mcgoldrick et al., 2012).

\footnotetext{
${ }^{15}$ Revised Conflict Tactic Scales (CTS-2). Traduzido por Moraes et al. (2002).
} 


\section{Estratégias de coleta e análise}

As entrevistas foram semiestruturadas e focadas no problema (Witzel, as cited in Flick, 2009). Nas entrevistas focadas no problema, o entrevistador decide momentos do roteiro em que introduz seus interesses temáticos, a fim de diferenciar os tópicos (Witzel, as cited in Flick, 2009). As induções — planejadas ou não — vão dos conteúdos gerais para os específicos.

As entrevistas foram gravadas em áudios e transcritas, e posteriormente submetidas a análise de conteúdo. Entre as formas de análise de conteúdo, Minayo (2010) aponta como adequada para investigações qualitativas em saúde a análise temática. Essa análise envolve a verificação da frequência, mas vai além para incluir a seleção de unidades dentro do corpus associadas ao tema da pesquisa. Essa busca garante acesso a materiais que não encontram relevância quantitativa, mas podem esclarecer relações entre as unidades temáticas. A análise de conteúdo temática privilegiou a complexidade, a dinamicidade e, inclusive, os conteúdos conflitantes apresentados pelos participantes que estavam relacionados aos temas pertinentes à violência conjugal. O delineamento da pesquisa geral foi de estudos de casos múltiplos, particularmente dois (Yin, 2010).

\section{Resultados e discussão}

Neste artigo, o foco da análise do material e discussão recai sobre a categoria construções da sexualidade e violência sexual. Essa categoria será discutida com base nos conteúdos trazidos pelos membros dos casais que vivenciaram situação de violência. Serão apresentados e discutidos os dados do casal V e do casal K. O Quadro 2, abaixo, mostra os dados sociodemográficos de cada casal. 
Quadro 2 - Dados sociodemográficos

\begin{tabular}{|l|c|c|c|c|}
\hline \multirow{2}{*}{} & \multicolumn{2}{|c|}{ Casal V } & \multicolumn{2}{c|}{ Casal K } \\
\cline { 2 - 5 } & Sr. V & Sra. V & 30 & Sra. K \\
\hline Idade & 41 & 38 & Superior incompleto & Superior incompleto \\
\hline Escolaridade & Ensino médio & Pós-graduação & De 1 a 2 & De 1 a 2 \\
\hline Renda (salários) & De 3 a 4 & Mais de 4 & Acredita em Deus & Evangélica \\
\hline Religião & Católico & Evangélica & Branca & Branca \\
\hline Cor/etnia & Parda & Parda & & \\
\hline
\end{tabular}

\section{Construções da sexualidade e violência sexual}

\section{Casal V}

A violência na família de origem costuma ser uma herança comum entre pessoas que recorrem à violência em suas dinâmicas relacionais. O Senhor V começa relatando as tentativas de controle de seu pai: "Ele só preserva muito, assim, quer preservar, mas não tem força. [...] As netas, quer se intrometer, dar um conselho: 'Porque está vestindo uma roupa com um decote grande'. 'Está vestindo um short que é muito curto". O Senhor V relata discurso de controle similar na igreja: "O padre um dia desses chamou atenção: 'Porque vai uma menininha nos seus 15, 16, 17 anos para a frente, com a calça muito colada. Vai uma menininha com decote. Vai outra com a saia que não tampa nada'. Então o padre chegou e reclamou que lá na igreja não é o lugar de andar dessa forma: "Você pode vir para a igreja assistir à missa, mas sem mexer com ninguém"”.

A Senhora V também relatou como sua vó exercia controle sobre as filhas mulheres: "Minha vó não deixava às vezes sair para namorar, tinha que ser na sala mesmo. Então ela não dava liberdade para nada. As meninas, não sei, pelo que eu ouço, assim, casaram, a maioria assim tudo virgem, porque minha avó não dava abertura de nada". A Senhora V relata que o controle se estendia para outros ambientes: 
Minha tia gostava de jogar handebol e ela só podia fazer o tal do CID antigamente, que era da escola pública, se eu fosse junto com ela. ${ }^{16}$ Se eu não fosse, minha avó não deixava. [...] Depois, nem minha tia podia ficar, porque ela tinha uns namoradinhos dela, mas depois teve que sair, porque minha vó não... [...] Eu era pequenininha. Eu lembro que eu tinha uns 6, 8 anos. Mas eu ia nesse negócio, que minha vó achava que ficando comigo ela estava segura e não ia aprontar nada.

A Senhora V relata as posturas da mãe diante de seus namoros: "Minha mãe: 'Ah, o ex-namorado da Senhora $V$ sempre foi uma gracinha'. Só que minha mãe não sabe que a minha primeira relação foi com ele. Ela pensa que foi o segundo, que ela odeia. Ela fala que odeia esse menino até hoje. O fato de ela achar que foi com o outro, ela fala: 'Esse fez minha filha andar no caminho errado, o outro não"'. A Senhora V expõe a diferença de tratamento entre homens e mulheres na sua família: "Sempre que eu via, e família comentando. Era assim, que homem, por mais que homem traísse, o homem... era o papel de homem. Mulher não podia fazer. Sempre essa coisa do machismo, machismo".

As representações do controle sexual da mulher aparecem associadas à família, à igreja, à escola e às relações conjugais e extraconjugais no discurso do casal V. A posição subjetiva em que as mulheres são colocadas inclui o outro como alguém que exerce controle sobre sua sexualidade, com pouco questionamento sobre liberdade ou direitos sexuais (Gagnon, 2006). Além disso, há o valor explícito de que não se relacionar ou controlar a conduta sexual é um trabalho a ser feito sobre a mulher e internalizado por ela, que deve se controlar (Heilborn, Aquino, Bozon \& Knauth., 2006).

A Senhora V fala sobre a situação atual no relacionamento:

16 Os Centros de Iniciação Desportiva ofereciam modalidades desportivas que o estudante selecionava para as práticas da educação física, substituindo ou não a atividade na escola. 
Antigamente eu não podia ir ali. Não podia sair, não. Não, isso mudou. A questão da roupa ainda, nossa, ele me enche o saco demais: “Ah, não vai com essa roupa, que não sei o quê, não sei o quê". "Você não me conheceu, você me conheceu assim." "Não, mas já mudou." "Não, eu não mudei, não. Continuo a mesma."

A Senhora V relata outras formas de tentativas de controle: “Às vezes, na hora dele pegar meu telefone, ficava uma marca. Ele: 'Não, vou pegar seu telefone, porque esse telefone...' Era sempre essa neura de pegar meu telefone, para ver o que que tinha no telefone". Algumas formas de controle envolviam terceiros: "Ele diz que não tinha [um GPS ou outro mecanismo para saber onde ela estava], era mesmo ele me seguindo. Mas tinha hora que eu ficava naquele cuidado, olhando, e eu não enxergava. [...] Ele veio, agrediu um colega meu que estava dormindo dentro do carro. A gente estava sentado num barzinho, eu, minha amiga e mais outro colega". O controle envolvia suposto pretendente a novo cônjuge: "Quando a gente estava separado, igual eu falei... Quando ele ficava me seguindo, se ele via uma pessoa, ele queria agredir essa pessoa. Um amigo meu, ele: “Ah, eu vou matar! Você quer acabar com o meu casamento?”

O controle da sexualidade parece envolver algum tipo de escalada da violência, como relata a Senhora V:

Eu estava de costas e a pessoa do lado. Aí ele pegou e deu um tapa na cadeira. Eu: "O que foi?"

"Você vai embora agora!" "Não vou." Aí ele: "Você vai!" Pegou a chave do meu carro... Não, pegou os meus documentos. Pegou: "Você vai!" Me puxando assim. Falei: "Me solta, me solta!" [...] Aí ele pegou, rasgou a minha roupa. "Você não vai sair?"

A Senhora V interpreta a intenção dele: "Que eu voltasse para casa. Porque assim, ela [a camisa] está rasgada: 'Não vai ter coragem de sair”.

As representações que envolvem o controle sobre a sexualidade e os corpos das mulheres são comuns à vida do casal V. As tentativas de controle da sexualidade da mulher na conjugalidade desse casal estão roteirizadas no cenário cultural em que se 
encontram, ou seja, contêm estrutura coercitiva e violenta. As mulheres e os homens vivem uma situação de dupla moral em relação ao exercício e controle sexual, em que há restrições e "liberdades" (Goldenberg, 2005; Jablonski, 2007). O impedimento dos direitos sexuais da Senhora V e a violência sexual perpetrada pelo Senhor V são atitudes inscritas em um roteiro que tem como pano de fundo essa dupla moral.

O Senhor $\mathrm{V}$ fala das práticas sexuais como uma dimensão garantida na conjugalidade: "Minhas piores experiências, ou a pior, não sei. A pior foi a nossa separação. [...] Você ter uma garantia e daqui a pouco essa garantia sua acaba". Ele relata uma das funções do sexo para o casal:

Querendo ou não, aquelas discussãozinha besta, boba, que um fica emburrado daqui, outro dali. Um de cara fechada. Qual é a reconciliação? Você não vai ficar o resto da vida ou o mês sem conversar com a sua esposa, com a sua mulher, com a sua companheira. Não vai. Então a melhor reconciliação dos dois começa por um pedido de desculpas, um perdão, um abraço, um beijo, e o final de tudo... [...] Não que seja um objeto para poder você, só ali, usar e acabou. Não, eu acho que sim, tem que ter o interesse de ambas as partes.

A Senhora V também se manifestou sobre essa função do sexo: "Quando você está brigando, às vezes, você não quer muito, não. Quando eu brigo com ele, eu: 'Não, não. Não vem de coisa, não’. Eu acho engraçado que, quando tem uma relação assim, no outro dia... A gente está brigado, ele continua brigado. Eu não. Já teve relação, quero ficar de boa".

O Senhor V menciona ainda outra função das práticas sexuais:

Você pode estar perdendo uma oportunidade. Porque o ato sexual, não vai dizer que o cansaço vai te atrapalhar: "Porque eu passei o dia todo cuidando da criança. Estou morta de cansada". Não. Você quer ver o seu parceiro feliz. Você quer ver a pessoa do seu lado feliz. Por mais que você esteja cansado, não seria muito mais bonito... [...] Você vai no banheiro, toma aquele banho, se perfuma toda e serve seu parceiro. Olha que ato bonito você fez. Depois daquilo ali, beleza, você vai cair na cama. Você vai acordar no outro dia com um sorriso na orelha. Então o 
cansaço muitas vezes não é um empecilho. O empecilho, sim, é você falar que está cansada. Você está arrumando desculpa para cumprir aquilo ali.

A construção dos roteiros sexuais que envolvem o casal $\mathrm{V}$ toma a conduta sexual como uma forma de resolução de conflitos, como algo garantido na conjugalidade e uma obrigação da mulher. Esse tipo de crença favorece a alienação do direito à liberdade sexual da mulher em favor do preceito do homem de poder dispor do corpo feminino (Dantas-Berger \& Giffin, 2005; Diniz, 2013). As práticas coercitivas são favorecidas quando tais roteiros estão inseridos no imaginário, na identidade de gênero, e permeiam a conjugalidade.

A Senhora V relata formas de coerção sexual sem uso da força:

Às vezes, você não está com tanta vontade e a pessoa quer. Você já fez, eu já fiz. [...] Mais para me deixar quieta. Toda mulher já fez isso. Não vai me deixar quieta. Estou morta. Pelo amor de... Para eu dormir. Estou morrendo de sono. [...] Mas assim, nada de agressão. Às vezes: “Ah, vou fazer logo, que eu quero dormir logo". [...] Para parar a insistência. Não que venha a agressão aí, não.

O Senhor V assume a intenção de perpetrar a coerção sexual: "Eu já estou para dar um cartão vermelho (risos): 'Oh, minha filha, como é que é?' [...] Ela diz que não pode engravidar... Porque não pode também engordar... Porque está tomando umas medicações. Ela tem que estar bonita no casamento. Aí eu não posso não, é?! Essa desculpa aí, não sei se vai colar, não".

Questionado sobre o que mudaria se um casal parasse de fazer sexo, ele diz: “Oh, pode ir embora. Pega suas malas. É, pode pegar e ir embora. Não tem palavra, não. [...] Não faz diferença? Faz. Faz. Faz diferença, sim. Embora sem, meu amigo, sem é complicado. Não tem. 'Se tu não quer, tem outro que quer'. Então essa é a realidade”. O 
sexo parece ser visto como o marcador fundamental, o elemento que atesta a existência da relação.

Ao comentar sobre a cena de estupro conjugal que resultou em sua prisão, o Senhor V afirma: "Por minha parte, não. Minha parte, não. Agora, pode ser pelo conceito da outra pessoa. O que eu acho que não, para ela pode ser constrangimento, sim”. Subsequentemente, o entrevistador pergunta se ela pode ter interpretado mal, e ele responde: "Com certeza sim".

Já a Senhora V assim narra o estupro conjugal: "Eu falei: 'Senhor $V$, pelo amor de Deus. Você está bêbado. Tem a medida protetiva. Pelo amor de Deus, vai embora'. [...] 'Você vai! Eu quero fazer amor com você!' Eu falei: 'Não, eu não quero'. E ele: 'Você vai fazer, sim!', bem transtornado. 'Você vai fazer amor!' 'Não, eu não quero.' [...] Nessa hora, eu falei: 'Não adianta eu medir forças com ele"'.

A Senhora V fala das interpretações dele sobre o ocorrido:

$\mathrm{O}$ fato de eu ter cedido e agido normalmente para ele pareceu que estava tudo normal. Então assim, ele confessou: "Senhora $V$, eu nunca pensei que tivesse..." Depois a gente conversou muito. Ele falava assim: "Eu nunca pensei que tivesse te feito tão mal. Que você não queria, que eu estava fazendo uma coisa que eu falava que não queria. [...] "Eu pensei que estava tudo normal. Que a gente ia ficar numa boa." Nesse dia não foi assim.

Os roteiros sexuais são construídos em um contínuo que vai desde as condutas sexuais mais rotineiras, com sua dupla moral, até os estupros. A expressão "fazer amor", seguida da frase que denotava força e obrigatoriedade "você vai fazer", deixa clara uma imposição, a prerrogativa do homem que precisa ter seu desejo satisfeito, sua vontade atendida. A interpretação do Senhor $\mathrm{V}$ de que eles ficariam bem depois do ocorrido expressa um mito presente na cultura de que o sexo tem o poder de apagar malentendidos, de consertar tudo. 
Os padrões da conjugalidade violenta permeada pelo controle, por coerções sexuais e por representações do corpo feminino como disponível (garantido) ficam evidentes nesse episódio. A violência sexual, desde a mais corriqueira à mais grave, infelizmente não é um ato ocasional na situação de violência conjugal. Estudos indicam que, nas representações mais comuns de virilidade, assim como nas situações de violência conjugal, há uma estreita relação entre os ideais da masculinidade hegemônica e a busca pelo controle dos desejos e vontades das mulheres (Diniz, 2011, 2013; Machado, 2004).

\section{Casal K}

O Senhor K retrata aspectos de sua educação ligados à sexualidade:

Já tinha orientação sexual na escola nessa época, de prevenção, de uso dos preservativos, das fases da mulher, da menstruação. Minha mãe já reforçava isso, questão de zelo e respeito com a mulher, que ela tem certas fases, que podem ocasionar certas coisas. Então não tinha muito segredo em relação a nada disso. E a descoberta depois, sexual, acho que foi no namoro mesmo.

Ele continua: “A primeira relação também foi muito clara para minha mãe: 'Olha, tive uma relação com outra pessoa'. Na mesma hora, ela perguntou se eu tinha me prevenido, usado preservativo e tal. Primeira coisa. Você tem que tomar cuidado, você precisa se prevenir de, relembrando de doenças, relembrando de coisas que podiam acontecer".

A Senhora K fala de uma conversa de sua adolescência: "Quando eu namorei a primeira vez... [...] Eu fui na casa de um namorado. Minha mãe não gostava que eu ia lá. A conversa que tinha era: 'Ah, se você arrumar um filho, não pensa que ele vai assumir você'.” A Senhora K comenta também um aborto que aconteceu na família:

Minha tia falou que a minha prima ia ser $X$. Eu lembro. Eu tenho memória dela grávida e eu e a minha prima pegando na barriga dela. Foi muito sofrido. A minha mãe diz que a família fala que 
realmente não era para ser, porque no enterro diz que a menina era tão linda, tão linda, parecia um anjo. [...] Parecia um anjinho, assim, que era só mesmo para devolver para Deus. Foi sofrido. Ela não pode engravidar mais depois disso. Foi complicado.

Na sequência, ela relata um encontro com uma amante de um tio, que indicou estar ressentida por ter sido obrigada a abortar:

Foi impactante, porque ela chegou a engravidar, só que ela fez aborto. [...] Não, não foi um acidente. Ele pediu para ela abortar. [...] Eu lembro, eu lembro que uma vez a gente encontrou ela na rua, eu, minha mãe e minha tia. Minha tia estava grávida da minha prima. Essa mulher falou: "Por que que eu não pude ter um filho e agora ela está grávida? Pois eu espero que a neném também não nasça".

Por sua vez, o Senhor K menciona uma meia-irmã que ele não chegou a conhecer:

Mais delicado em relação a esse contexto, a minha irmã, foi que minha mãe teve que doar. Por pressão da família, por pressão do meu avô. Porque não tinha como casar, e ele com essa questão do casamento era muito rigoroso. Meu avô não admitiu que minha mãe ficasse com a neném sem ser casada, e ele a forçou a fazer isso. [...] Ela morava com meu vô, na casa dele. Ela não tinha uma residência. Então todas as regras, todas as normas, quem ditava era meu avô. Ela era muito nova. [...] Meu vô fez questão de que fosse um processo sigiloso para que minha mãe não sofresse depois, para que não fosse atrás e que não tivesse algum tipo de contato.

Sabe-se, inclusive, que foi para uma família de diplomatas na época, da alta sociedade de cidade onde o Senhor K morava na infância. [...] Minha mãe não sabe quem é a família, minha mãe ficou totalmente impossibilitada de saber para quem foi. [...] Isso teve um apelo muito forte para a vida da minha mãe, tipo no psicológico. Ela não conseguir aceitar nenhum tipo de perda, nenhum tipo de... Literalmente, ela dedicou a vida dela todinha pra mim. ${ }^{17}$

${ }^{17}$ Um aspecto do cenário cultural que é importante ser salientado — apesar de não poder ter a discussão que merece no presente trabalho - é que o avô do Senhor K era militar no contexto da ditadura militar brasileira, que promoveu uma série de sequestros de crianças que foram adotadas por outras famílias tradicionais no mesmo período. A irmã do Senhor K foi “doada” em 1981. A maioria dos sequestros no período se encontra na segunda metade dos anos 1960 e durante os anos 1970, mas as práticas institucionais dos militares possivelmente subsidiaram essa violação. 
Fica clara, na biografia do Senhor K, a força da relação de triangulação que afeta a conjugalidade e de posse e controle da mãe sobre o filho. Viu-se ainda que, na história do casal K, a educação sexual em casa e na escola é voltada, também, para a prevenção da gravidez. O Senhor K, ao relatar uma grave violação aos direitos reprodutivos - a coerção perpetrada por seu avô contra sua mãe, obrigada a dispor da filha sem anuência - , fala da rigidez moral e dos princípios normativos que regem o exercício da sexualidade em sua família.

As heranças geracionais, somadas às marcas e às consequências dessa violência, podem ser elementos que nos ajudam a compreender a formação de uma díade rígida entre o Senhor K e sua mãe. Essa díade leva à relação de triangulação que influencia a conjugalidade e à posse e ao controle da mãe sobre o filho, assim como à competição agressiva entre a mãe do Senhor K e a Senhora K. É importante lembrar que a Senhora $\mathrm{K}$ mencionou casos de aborto na sua família, relacionados com cenas de sofrimento e submissão da mulher.

A Senhora $\mathrm{K}$ relatou a ocorrência de gravidez na família associada a violência conjugal, com danos graves. A gravidez é um processo que envolve vulnerabilidade e maior risco de violência conjugal e familiar contra a mulher, o que potencializa danos à mãe e ao bebê (Audi et al., 2008; Kronbauer \& Meneghel, 2005; Moraes, Arana \& Reichenheim, 2010). Ela narrou uma violência perpetrada pela mãe do Senhor K, que fez uma ameaça de grave violação de seus direitos reprodutivos: "Eu descobri a minha gravidez. Dias depois, eu vi uma mensagem no celular dele: 'Aborta logo!' Eu entendi que era ela pedindo para abortar. Porque, quando eu engravidei, ele sugeriu que eu abortasse a criança. Eu falei que não, que apesar de a criança não ter sido planejada, eu não iria fazer aborto de maneira alguma”.

Diante desse desentendimento, a Senhora K relata que o casal passou alguns dias brigado. Ela diz que ele falou: 
"Você vai abortar nem que seja a força!", e eu falei que não. Aí eu vi essa mensagem no celular dele. E eu entendi, realmente entendi que ela que tinha pedido para ele abortar. Aí passou uns dias, a gente fez as pazes. Aí não a vi. Aí, quando foi num sábado, eu estava tendo um pequeno sangramento. Fomos ao hospital. Estava tendo um pequeno descolamento de placenta. Aí foi aquelas recomendações: "Você vai ter que ter repouso. Nada de passar por estresse e tudo mais". $[\ldots]$

No outro dia, de manhã, [...] a mãe dele chega lá na nossa casa e ele vai pra praça com ela. [...] Cheguei lá na praça, ela falou: “Oi!” Aí eu fiquei calada. Não conseguia responder, porque eu entendi na mensagem que era aquilo. Ele falou: "Não vai falar com a minha mãe, não?" Falei: "Não, não sou obrigada a falar com quem quer matar o meu filho".

A Senhora K conta o ato subsequente: "Ela começou a me bater, a me dar tapa, me dar tapa, só que foi tudo tão rápido. Ele me segurou e ela meio que me afastou. Falou: 'Você é louca, eu sou sua mãe. [...] Mãe tem direito de bater no filho'. Eu virei para ela e falei: "Você não é a minha mãe"'.

O contexto de violência sofrida pela Senhora K durante a gravidez — no qual a ameaçam, tentam forçá-la a abortar e a agridem fisicamente — é permeado por um processo de transmissão transgeracional. Uma vez que a mãe do Senhor K foi impedida de ficar com seu primeiro bebê, e que mantém uma relação fusionada com o filho, podese depreender que ela pede o aborto para garantir (mesmo que inconscientemente) a manutenção de seu lugar e de seu poder sobre o filho.

Esse ato aponta para outro cenário importante na história do casal K. A gravidez é representada como algo a ser evitado. É vista como um período marcado pelo sofrimento e pela submissão da mulher ao desejo e à autoridade de um outro masculino, que passa a deter o poder sobre seu corpo e seu destino. Sua vontade é secundária se comparada às prerrogativas da moral patriarcal.

A gravidez também é vista como processo que implica risco para a mãe e para o bebê, como consequência de situações de violência ou de morte natural do feto. A 
violência sexual, em que a Senhora $\mathrm{K}$ tem seus direitos reprodutivos cerceados, se dá em um contexto maior de violência familiar e conjugal. Os relatos na família do casal $\mathrm{K}$ de uma pessoa que obrigou a amante a abortar, de uma mãe que foi obrigada a entregar a filha e de um tio que agride a tia grávida indicam novamente a realidade cerceada do corpo feminino - um corpo sujeito à submissão e à violência associadas à gravidez e aos preceitos morais (Audi, Segall-Corrêa, Santiago, Andrade \& Pèrez-Escamila, 2008; Kronbauer \& Meneghel, 2005; Moraes et al., 2010).

A reedição dessa perspectiva sobre o corpo feminino acontece na situação de coerção que envolve o próprio casal $\mathrm{K}$ e, de modo especial, a Senhora K durante a gravidez. Estudo de Pilecco, Knauth e Vigo (2011) apontaram associação entre coerção sexual e aborto provocado, além de complicações no controle da sexualidade e da reprodução.

O Senhor K afirma não forçar relações sexuais:

Da minha parte, não. Toda vez que ela falava que não queria, que não estava disposta, eu: "Não? Ah, tudo bem. Então a gente faz outro dia”. Nunca insisti. Nunca forcei nenhuma situação de sexo contra a vontade dela. Já insisti com relação a posições e tudo, mas só insistência. Forçar mesmo, não. Insisti. Pedi várias vezes: "Não, vamos fazer assim. Vamos fazer assim. Vamos experimentar. Vamos lá”. Só de ficar instigando, mas de forçar, não.

A Senhora K, ao responder se já fez sexo contra a vontade, fala:

Já aconteceu, por exemplo, de eu já estar sonolenta, de eu já estar dormindo. Ele estar interessado e aí [ela ri]: "Fica de ladinho, amor". Ele faz sexo sozinho [ri muito]. [...] Não é algo que... Não me traz prazer, mas eu não me incomodo. [...] No outro dia: "Amor, eu estou me sentindo meio estranha. Aconteceu alguma coisa?" "Sim, aconteceu." “Ah, está explicado.” Sim, já aconteceu. Já dormi literalmente. Eu tenho um sono muito pesado [risos].

A Senhora K comenta, ainda, sobre as cenas em que o Senhor K faz sexo com seu corpo: 
Está aí, uma coisa que me incomoda. Não dele, não de acontecer isso, mas às vezes que ele me procura é mais assim. [...] Talvez uma vez por semana isso aconteça. [...] Talvez seja algo que me incomode, no sentido de... não é que ele não me procura, mas eu acho... não sei, porque ele não me procura de dia, quando eu estou mais disposta. [...] "Poxa, você estava lá sozinho, parece que eu não existo.”

O que a Senhora K caracteriza como incômodo indica a objetificação e o assujeitamento como motivos de sofrimento. A necessidade de corresponder aos desejos e às necessidades sexuais do outro é concomitante à anulação do eu da Senhora K. O consentimento prévio ou posterior à conduta sexual praticada sem sua consciência não minimiza a violência ali presente, já que o roteiro sexual é caracterizado pelo uso do corpo de alguém para um fim que causa incômodo ao sujeito ausente desse corpo. A Senhora K interpreta essa forma de estupro conjugal como uma indicação relacional de que ela não existe, ou seja, é desconsiderada em sua condição de sujeito.

A Senhora $\mathrm{K}$ fala também sobre quem toma a iniciativa sexual: "É porque como nas outras vezes sou eu que tomo mais a iniciativa, não sei explicar. Eu sinto que ele toma mais iniciativa dessa forma [com ela dormindo ou com muito sono] do que de outras formas". O Senhor K afirma que não pratica nada sob uso da força, mas que insiste, o que indicaria a coerção sexual (Cordeiro, 2008; Cordeiro et al., 2009) como prática sexual disponível entre os seus roteiros. $\mathrm{O}$ fato é que ele minimiza e nega o desrespeito e o caráter de imposição e assujeitamento em uma de suas formas predominantes de fazer sexo com a Senhora K, que por sua vez é permissiva em relação a uma prática sexual que a incomoda e não é de seu interesse. Ela descreve a conduta sexual ritualizada do Senhor K: ele espera ela ter muito sono ou dormir e pratica sexo com o corpo dela.

A ausência de consciência é uma das vulnerabilidades que impossibilita o consentimento para o ato sexual. Apesar disso, aparentemente, a Senhora K permite o 
uso do seu corpo, com ou sem consciência, apesar de preferir estar consciente. A apropriação e o uso do corpo do outro caracterizam o uso da força que instaura a violência sexual. $\mathrm{O}$ estupro conjugal marcado pela impossibilidade de consentimento dada a situação de inconsciência é agravado por reencenar, ritual e regularmente, o assujeitamento e a passividade destinados ao feminino.

Machado (2004, p. 36) refere que sua escuta com estupradores aponta "uma concepção de sexualidade que antagoniza o masculino como sujeito da sexualidade e o feminino como objeto da sexualidade". A encenação de um ritual de poder e controle sobre o corpo aproxima o feminino do imóvel, daquele que não impetra impedimento, alteração ou desejo. A relação entre as concepções de masculinidade e feminilidade, marcadas pelos estereótipos de gênero, e as práticas sexuais do casal K, consentidas ou não, é evidente.

A Senhora $\mathrm{K}$ fala o que pensa a respeito do lugar do sexo:

O sexo não é o mais importante para o casamento, mas é fundamental. Então eu acho que, se não tiver atração física, se não tiver sexo, então eu acho que não tem casamento. [...] Se perde isso, perde a atração, perde a vontade... porque é tão natural o ser humano sentir atração, sentir necessidade. [...] Se eu não sinto mais atração por ele e ele não sente mais atração por mim, então ou ele está sentindo por outra pessoa, ou eu estou sentindo por outra pessoa. [...] Então, se não há sexo dentro do nosso casamento, provavelmente está havendo fora.

Essa fala da Senhora K é relevante para questionar em que medida o fato de o Senhor K semanalmente fazer sexo com seu corpo, ou seja, com ela dormindo e sem seu consentimento a faz pensar que ele não sente mais atração por ela. Ela pode sentir dificuldade de admitir isso, pois a faria questionar o pressuposto da presença da atração, que parece ser importante para ela.

A Senhora K diz que o sexo já ajudou o casal K: "Não sei, mas eu acho que sim. Por exemplo, ele estava estranho comigo. Aí eu vou lá, dou uma forçadinha. A gente 
acaba tendo uma relação e ele acaba normalizando. Isso acaba, entre aspas, deixando a relação mais agradável entre a gente. Então eu acho que sim. Não é que resolve, mas é uma ajuda".

O casal K aponta dinâmicas que compõem seus rituais e roteiros sexuais. Uma delas é a suposição de que falta de sexo é consequência de infidelidade. Outra delas envolve o imaginário do casal — ou pelo menos da esposa -, relacionado à visão de sexo como algo que diminui a tensão, depois de uma forçadinha. Os elementos que constroem a sexualidade do casal $\mathrm{K}$ instituem obrigações e favorecem condutas sexuais coercitivas e/ou violentas.

Os rituais conjugais comportam contradições entre significados e formas (Roberts, 2006). A Senhora K, aparentemente a fim de manter a conjugalidade e o bemestar, indica que perpetra coerções sexuais. O Senhor K pode sofrer coerção sexual, mas isso não implica necessariamente uma mudança do seu status, já que a ritualização das práticas que envolvem ele ter que ir para a cama e conviver com uma forçadinha é composta por contradições.

A Senhora K, ao mesmo tempo, tem motivações pautadas pelos processos de engendramento que marcam o lugar do feminino — por exemplo, a ideia de ser responsável por usar a sexualidade para arrefecer os ânimos. Ela incorpora o papel de gênero tradicional de arcar com a responsabilidade pela manutenção da conjugalidade e pelo abrandamento do mal-estar do outro.

O Senhor K fala de suas restrições a essa dinâmica:

É desconfortável às vezes. Às vezes, eu fico sem graça. Porque às vezes não é de um jeito que eu quero. Às vezes não é num momento que eu quero também. As vezes que eu não quero, ela fica sem graça, fica chateada. Acha que eu estou... Aí exagera, acha que eu estou desprezando ela, que eu não quero mais ela. Aí inventa um monte de coisas que não tem nada a ver. "Não, eu não quero agora. Eu não quero assim.” Às vezes acontece isso. 
O Senhor K responde se já fez sexo contra a vontade:

Ah, sim. [...] Já teve outras vezes, sim. Não foi uma vez, só não. Teve outras vezes. Acaba na mesma condição, de chegar cansado, estar estressado e não querer. Não querer por cansaço físico. E ela animada, empolgada, querendo de todo jeito. [...] Nunca gerou discussão. Ah, ela ficava emburrada na hora ali, injuriada na hora ali, mas virava para um lado ali e dormia.

Ele continua: "Outras horas ela então forçava mesmo, forçava para querer me agarrar dormindo mesmo". E conta uma cena dessas cenas de coerção sexual:

Ela subiu em cima de mim, eu estava super agoniado, sem ar inclusive. Ela queria de qualquer jeito, me agarrar de qualquer forma. Eu não queria. Eu: "Não, não. Vou dormir”. Acabei ficando excitado, tudo, mas não foi legal. [...] Minha cabeça estava em outro lugar. Eu não estava ali. [...] Eu não queria, não estava a fim. Estava super cansado. Eu queria dormir. Ela insistindo, insistindo. Para mim não foi tão agradável.

O Senhor K interpreta os gestos da Senhora K: "Forçou, forçou uma situação que não estava tão em acordo".

A Senhora K, ao ser perguntada se já fez sexo contra a vontade do Senhor K, responde: "Provavelmente sim, no sentido de eu tentar estimular até a última circunstância. [...] Porque ao contrário, não sei, mas eu acho que ao contrário [risos] eu não tenho como fazer sexo sozinha, sem ele. Nós dois, mas sem ele estar de alguma forma [risos]".

Apesar de apresentar alguma ininteligibilidade sobre os estupros perpetrados pelos dois - ele quando pratica sexo com o corpo da mulher sem consciência e ela quando força a conduta sexual -, o casal $\mathrm{K}$ indica claramente práticas de violência sexual. Os cônjuges apontam seus respectivos incômodos, quando na posição de vítimas, mas parecem não ter consciência do que fazem na posição ativa. O Senhor K nem apresenta dados relativos a esses eventos, mesmo quando perguntado diretamente 
sobre violência sexual. Os roteiros sexuais e rituais conjugais do casal K revelam uma dimensão perversa, com um investimento na negação do outro.

O redimensionamento é bastante descrito na situação de violência conjugal e envolve justificativas, minimização, negligência, negação, anestesias (Diniz, 2011, 2013; Diniz \& Pondaag, 2004, 2006; Pondaag, 2009; Ravazzola, 2005). No contexto do casal $\mathrm{K}$, o redimensionamento incide em um jogo de poder que ignora o afeto, as necessidades, o propósito de compartilhar prazer e a própria condição do outro como sujeito que existe e decide sobre sua sexualidade.

A Senhora K estuprar o Senhor K é pouquíssimo inteligível na fala deles, apesar de os dois se referirem a práticas sexuais forçadas por ela. Aqui, além dos redimensionamentos comuns à violência conjugal, a própria posição subjetiva e a estruturação dos corpos masculino e feminino impossibilitam a inteligibilidade do estupro conjugal perpetrado pela mulher. No caso das aparentemente corriqueiras cenas de estupro praticado por ele, a dificuldade de inteligibilidade pode advir da ideia de que ela "sabe" da prática e consente com ela, mesmo que não possa fazê-lo quando a violência sexual acontece.

O contínuo que vai da sedução para a coerção sexual, com o sexo forçado (estupro conjugal) que aparece no discurso dos estupradores presos (Machado, 1998), está presente nas condutas sexuais e significações da violência para o casal K. A interpretação dos gestos e das formas de controle violadores é estruturada em uma concepção de transformar o não em sim, como na sedução. No caso da Senhora K, nem a sedução parece necessária, já que ela nem tem direito à voz ou à interação como parceira no ato. Pode-se depreender, dada a natureza do ritual descrito, que o sim dela pode ser a atuação de se fingir de morta, a entrada na cena de assujeitamento, que inclui sua submissão ao desejo dele. 


\section{Sexualidade e táticas de conflito}

O instrumento Revised Conflict Tactic Scales (CTS2) foi traduzido para uma versão em português (Moraes, Hasselmann \& Reichenheim, 2002). Nesta pesquisa, a aplicação dele contou com as escalas de coerção sexual, violência física, injúria, negociação e agressão psicológica. Na tabela a seguir, os números são as posições das questões da escala de coerção sexual no instrumento completo (Anexo $1-\mathrm{F}$ ).

Quadro 3 - Respostas do instrumento CTS-2 relativas à coerção sexual dos casais

\begin{tabular}{|c|c|c|c|c|}
\hline & \multicolumn{2}{|c|}{ Casal V } & \multicolumn{2}{|c|}{ Casal K. } \\
\hline & Sr. V & Sra. V & Sr. K. & Sra. K. \\
\hline $\begin{array}{l}\text { 8a Você obrigou o seu companheiro(a) a fazer sexo sem usar } \\
\text { camisinha? }(\mathrm{Cm})\end{array}$ & Não & Não & Não & Não \\
\hline 8b Seu companheiro(a) fez isso com você? $(\mathrm{Cm})$ & Não & Não & Não & Não \\
\hline $\begin{array}{l}\text { 10a Você usou de força como, por exemplo, segurar ou bater } \\
\text { nele ou usar uma arma, para obrigar o seu companheiro(a) a } \\
\text { fazer sexo oral ou anal com você? }(\mathrm{Cg})\end{array}$ & Não & Não & Não & Não \\
\hline 10b Seu companheiro(a) fez isso? $(\mathrm{Cg})$ & Não & Não & Não & Não \\
\hline $\begin{array}{l}\text { 24a Você usou de força como, por exemplo, segurar ou bater } \\
\text { nele ou usar uma arma para obrigar o seu companheiro(a) a } \\
\text { fazer sexo com você? }(\mathrm{Cg})\end{array}$ & Não & Não & Não & Não \\
\hline 24b Seu companheiro(a) fez isso? (Cg) & Não & $\begin{array}{l}\text { Sim } \\
1 \mathrm{vez}\end{array}$ & Não & Não \\
\hline $\begin{array}{l}\text { 26a Você insistiu em fazer sexo quando o seu } \\
\text { companheiro(a) não queria sem usar força física? }(\mathrm{Cm})\end{array}$ & Não & Não & Não & $\begin{array}{l}\text { Sim } \\
\text { Às vezes }\end{array}$ \\
\hline 26b Seu companheiro(a) fez isso com você? (Cm) & Não & Não & $\begin{array}{l}\text { Sim } \\
5 \text { vezes }\end{array}$ & $\begin{array}{l}\text { Sim } \\
\text { Poucas } \\
\text { vezes }\end{array}$ \\
\hline $\begin{array}{l}\text { 29a Você fez ameaças para obrigar o seu companheiro(a) a } \\
\text { fazer sexo oral ou anal com você? }(\mathrm{Cg})\end{array}$ & Não & Não & Não & Não \\
\hline 29b Seu companheiro(a) fez isso com você? $(\mathrm{Cg})$ & Não & Não & Não & Não \\
\hline $\begin{array}{l}\text { 32a Você insistiu para que seu companheiro(a) fizesse sexo } \\
\text { oral ou anal com você sem usar força física? }(\mathrm{Cm})\end{array}$ & Não & Não & Não & Não \\
\hline 32b Seu companheiro(a) fez isso com você? $(\mathrm{Cm})$ & Não & Não & Não & $\begin{array}{l}\text { Sim } \\
\text { Às vezes }\end{array}$ \\
\hline $\begin{array}{l}\text { 38a Você fez ameaças para obrigar o seu companheiro(a) a } \\
\text { fazer sexo com você? }(\mathrm{Cg})\end{array}$ & Não & Não & Não & Não \\
\hline 38b Seu companheiro(a) fez isso com você? $(\mathrm{Cg})$ & Não & $\begin{array}{l}\text { Sim } \\
1 \mathrm{vez}\end{array}$ & Não & Não \\
\hline
\end{tabular}


Estudo de Rosa e Falcke (2014) aponta os desacordos que o CTS-2 suscita nos casais em situação de violência conjugal. Os desacordos entre as interpretações das condutas e os roteiros sexuais entre os membros de cada casal participante desta pesquisa foram igualmente evidenciados nas respostas aos itens do instrumento. $\mathrm{Na}$ visão do Senhor V, nenhuma das formas de coerção foi usada por nenhum dos cônjuges. A Senhora V identifica o estupro que foi denunciado, nas duas respostas positivas que dá em relação à coerção sexual grave com uso da força e por meio de ameaça. Esse desacordo é coerente com a análise das entrevistas, nas quais o Senhor V minimiza o estupro e afirma que ela interpretou mal a situação.

Os papéis de homens e mulheres atravessados por prescrições tradicionais de gênero preveem o sexo na conjugalidade como uma obrigação das mulheres (DantasBerger \& Giffin, 2005; Diniz, 2013). Assim, a inteligibilidade da cena de sexo forçado como estupro presente tanto no casal $\mathrm{V}$ quanto no casal $\mathrm{K}$ fica dificultada para o Senhor V e para o Senhor K, pois eles estariam exigindo o que entendem como um direito deles.

O Senhor V exercia uma forma de dominação que instituía a posse da Senhora V desde o momento em que ela foi sua parceira. Entre os términos e as reconciliações, as cenas de controle coercitivo apontam que, para o Senhor V, ela deveria lhe pertencer, como diz ele, de forma garantida.

O Senhor K indica que sua companheira insistiu em fazer sexo sem uso da força. $\mathrm{Na}$ análise das entrevistas, ele indica claramente o uso da força, que caracterizaria coerção sexual grave para o CTS-2. A Senhora K entende que tanto ela como ele insistiram em fazer sexo, indicando coerção sexual menor para o CTS-2. Ela indica que a insistência dele se estende para a prática de sexo oral ou anal. Durante as entrevistas, o Senhor K afirma sobre essas práticas: "Ela não admite sexo oral. Não gosta, ela sempre falou que não gostava. Não tem. Já tentei até, insisti várias vezes, mas ela não gosta. Ela 
é muito franca nesse sentido". É importante ressaltar que ele indica a sua insistência durante as entrevistas, mas não a sinaliza no instrumento.

O casal K não apresenta nenhuma forma de coerção sexual grave no CTS-2, o que definitivamente não condiz com suas práticas sexuais, mas corrobora sua dificuldade de inteligibilidade e consequente negação. Durante as entrevistas, as formas de coerção sexual que podem ter interpretações mais graves foram minimizadas ou banalizadas, levando em conta a forma ritual como elas aconteciam, como no caso do Senhor K praticar sexo com o corpo dormindo da Senhora K.

As construções culturais sobre os papéis de homem e mulher também dificultam a inteligibilidade sobre o fato de ela forçar o sexo como uma forma de coerção sexual grave, já que se trata de uma mulher obrigando um homem a fazer sexo com ela. Essa dificuldade de inteligibilidade vai desde a construção corporal dos corpos masculinos como os que penetram e dos corpos femininos como os que são penetrados (Souza, 2009) até os cenários culturais que permeiam o estupro — tanto o que acontece em lugares públicos ermos e escuros, com desconhecidos, cuja execução envolve gritos, ameaças graves e roupas rasgadas, possivelmente relacionados com álcool e outras drogas, quanto o que acontece nos contextos relacionais (Cavalcanti et al., 2006; Machado, 1998).

A escala de coerção sexual do CTS-2 não pode ser desprezada como sinalizadora de violência, conforme indicado no estudo de caso dos casais envolvidos em situação de violência conjugal. Cabe ressaltar, no entanto, que a sua estrutura, com autorrelatos simplificados, também está sujeita aos redimensionamentos da violência que a minimizam, banalizam e negam. No contexto da sexualidade, estudo de Moraes et al. (2002) aponta que uma das principais questões que alteram o resultado do instrumento é o esquecimento e a negação proposital, como forma de adaptação à experiência da violência de difícil elaboração. Esse esquecimento proposital vai ao 
encontro da literatura que trata da violência conjugal como banalizada, minimizada, negada, justificada e anestesiada (Dantas-Berger \& Giffin, 2005; Diniz, 2011, 2013; Diniz \& Pondaag, 2004, 2006; Pondaag, 2009; Ravazzola, 2005).

\section{Considerações finais}

Este artigo tratou da presença de violência sexual no contexto da conjugalidade. A pesquisa realizada incluiu dois estudos de caso, cujos resultados foram parcialmente apresentados aqui. Os roteiros sexuais, rituais conjugais e genogramas sexuais foram investigados como meios para identificar as construções pessoais, geracionais e sociais que resultam em significações que organizam o exercício da sexualidade dos casais participantes.

Os resultados foram analisados com base em perspectiva que articula as dimensões de gênero e poder presentes nos roteiros sexuais e nos rituais conjugais. Foram identificadas construções e significações afetivo-sexuais que permeiam o exercício da sexualidade, e ficaram evidentes seus impactos na dinâmica de casais em situação de violência conjugal. As questões de gênero e poder atravessam as experiências identitárias, relacionais e afetivo-sexuais dos casais estudados. Também ficou claro que a violência conjugal e, de modo particular, a violência sexual são naturalizadas, invisibilizadas e silenciadas. Elas se tornam um problema de quem está envolvido diretamente com ela, o que as reifica, já que ocorrem em uma relação de suposto consentimento que mascara, em muitos casos, uma relação de poder enrijecida.

A violência sexual que é perpetrada na conjugalidade tem essas condições agravadas, pois várias dimensões da própria experiência da sexualidade não são comunicadas. Os roteiros sexuais e as construções da sexualidade já inscrevem as condutas sexuais na ordem do que não deve ser falado, muitas vezes nem mesmo entre 
os membros do casal. Esse silêncio dificulta a percepção do impacto desse tipo de violência, dificultando a mudança e a busca de ajuda.

O fato é que as dificuldades presentes na negociação entre os casais e as diferentes compreensões acerca dos direitos e deveres sexuais intensificam a gravidade das práticas sexuais coercitivas. A diferença de interpretação dos parceiros marca a dinâmica conjugal nos casos estudados, em que a violência sexual conjugal aconteceu com intenção e em contextos de poder e controle.

A relação entre o conceito de estupro conjugal e o consentimento é complexa, já que o consentimento pode ser dado mesmo diante de práticas coercitivas. A sedução também pode estar presente em representações que favorecem a violência sexual, na forma de sujeição do outro na tentativa de transformação simplista do sim em não. O estupro conjugal acontece em relações de poder nas quais os agressores, muitas vezes, utilizam ou conjugam força, ameaça e controle.

Paradoxalmente, no entanto, os membros dos casais que participaram do estudo, à exceção da Senhora V, referem-se defensivamente a situações de violência, fazendo um apelo à sedução ou à transformação afetiva por meio do sexo forçoso. O Senhor V e a Senhora $\mathrm{K}$ esperam que, depois de atuar sexualmente de forma violenta, a conjugalidade incorpore aquela prática como algo que amenizou os conflitos, que reforçou os laços do casal. O Senhor K, por sua vez, parece desconhecer ou negar amplamente sua prática sexual com a esposa dormindo como algo violento.

Os roteiros sexuais, utilizados como categoria de análise, orientam, organizam e estruturam a conduta dos casais do presente estudo. Os roteiros sexuais pautados em prescrições tradicionais de gênero têm o masculino estruturado como sujeito e o feminino estruturado como objeto. Essa diferença é levada ao extremo na violência sexual e no uso ritual do corpo da Senhora K dormindo, cenas de estupro que envolvem controle ativo protagonizadas respectivamente pelo Senhor V e pelo Senhor K. 
Os estupros que a Senhora K perpetra contra o Senhor K não são vistos por ela como tais, uma vez que são motivados por aspectos da construção social do feminino, a exemplo da manutenção da coesão da família e do exercício da sexualidade para diminuição das tensões do marido. No entanto, ela faz uso de uma posição relacional diferente quando "sobe" no companheiro e o força à prática sexual. Ela entende que pode ter controle sobre o corpo masculino, que sua força ativa pode submetê-lo. Apesar de as motivações do estupro indicarem uma posição subjetiva feminizada, a conduta sexual violenta remete ao masculino, o ativo dominante. Esse papel conflituoso dificulta a inteligibilidade do estupro conjugal. Apesar disso, a virilização sexual da Senhora K não se estende a toda a sexualidade e a conjugalidade. No contexto da sexualidade, ela é usada como objeto sexual. Na dimensão da conjugalidade, ela se cobra e continua sendo cobrada a ser uma boa mãe e dona de casa, fazendo uma jornada tripla. Ela se cobra também ter um papel de controlar os humores do marido, que chega tenso em casa e pode explodir por pouca coisa.

Os valores, as crenças e as significações que estruturam roteiros e práticas sexuais de homens e mulheres situam e organizam as cenas em que a violência sexual acontece. A violência sexual não ocorre ao acaso ou de forma ocasional. Para o casal V, ela acontece como forma de controle, manipulação e afirmação de posse sobre a cônjuge. Para o casal K, acontece como forma de resolução de conflitos estruturada na dinâmica conjugal e nas posições subjetivas dos companheiros.

As práticas sexuais e suas significações são construídas por duplas perspectivas — do homem e da mulher. As construções sociais em torno do sistema sexo-gênero posicionam homens e mulheres diferentemente e criam roteiros sexuais distintos em seus aspectos intrapsíquicos, interpessoais e culturais. Muitas vezes, essas diferenças aparecem enrijecidas e se manifestam em desigualdades estruturais que acabam favorecendo as situações de violência sexual conjugal. 


\section{IMPRESSÕES FINAIS}

As palavras finais são para lembrar que esta dissertação não apresenta nada definitivo, acabado, pronto. A intenção foi promover reflexão, abrir um diálogo, enfim, provocar... A expectativa é que as reflexões aqui apresentadas sejam pensadas, problematizadas, descartadas (se necessário), reorganizadas e redimensionadas, especialmente se for em prol de melhores formas de lidar com o sofrimento dos casais e famílias em situação de violência.

A violência doméstica implica ou deveria implicar a todos. É um problema social sem fim previsto e com características alarmantes no Brasil. A repercussão da violência doméstica não está limitada àqueles que se posicionam como vítimas e autores. A sociedade inteira convive com as consequências da violência, que, apesar disso, é representada como privada na distinção entre público e privado.

A dimensão da sexualidade comparece na sociedade de forma conflituosa. Há intensas exposições publicitárias do corpo e várias formas de controle e repressão de manifestações sexuais que são incentivadas e/ou sancionadas sem motivo explicitado. Os profissionais que lidam com a violência conjugal precisam se perguntar sobre as próprias representações dos roteiros sexuais e rituais conjugais.

Este trabalho não teve a pretensão de propor intervenções ou modelos para lidar com a sexualidade na situação de violência conjugal. Compartilho aqui, no entanto, algumas ideias a serem aperfeiçoadas. A inteligibilidade que condiciona lidar com os papéis de homens e mulheres como posições heteronormativas e a rigidez presente na dupla moral sexual precisam ser colocadas em questão. A práxis deve ser sensível aos desafios colocados pelo sistema sexo-gênero e às expressões práticas e discursivas que envolvem a conduta sexual. 
A sexualidade pode parecer uma dimensão da vida mais exposta do que deveria, mas uma discussão sensível ao sofrimento precisa envolver aspectos da sexualidade que, muitas vezes, não estão na superfície relacional cotidiana. Essa postura pode ser diferenciada da inundação irrefletida de exposições publicitárias dos corpos e das receitas prontas acerca das experiências sexuais. Mais que isso, a dimensão da sexualidade precisa, em contextos específicos, ser convidada a entrar nas relações. A categoria gênero, mesmo em palestras para adultos, muitas vezes é explicada conforme parâmetros associados ao universo infantil, das cores rosa e azul, ou dos brinquedos infantis, como bola, carrinho e boneca. Esses exemplos podem ser muito úteis para facilitar a aproximação, mas é preciso ir mais fundo.

Todos nós convivemos com as representações sexualizadas dos corpos femininos, com a representação social de que a atividade sexual masculina é irrefreável e potencialmente agressiva, com a infidelidade naturalizada no masculino, o controle sobre a sexualidade no feminino etc. É preciso considerar a sexualidade que, de outro jeito, seria obscurecida.

Minha orientadora me disse algumas vezes ao longo de nossas conversas: "A gente ainda não aprendeu a falar sobre a sexualidade". Essa é uma fala que encontrou muitas ressonâncias em mim. A conduta sexual é representada como espontânea, algo que acontece sem nenhuma forma de construção ou aprendizado, como se os corpos tivessem suas forças e encaixes naturais. Esta pesquisa mostrou que isso é uma falácia. A sexualidade é pautada por não ditos, silêncios e segredos. O paradoxo é que, ao ser marcada pela violência, ela precisa ser revelada. Tal revelação tem o potencial de abrir espaço para diálogo e reflexão. O fato é que, da mesma forma que aprendemos a construir roteiros sexuais, precisamos aprender a falar sobre a sexualidade e compartilhar os processos de engendramento que definem suas pautas. 
Os profissionais que lidam com a violência conjugal precisam receber apoio e treinamento para incluir em suas práticas reflexões sobre a sexualidade e deixar mitos, valores e significações sexuais entrarem na discussão. A violência sexual muitas vezes não será mencionada, mesmo por uma pessoa que está denunciando ou sendo atendida por situação de violência conjugal. Práticas sexuais violentas, em muitos casos, não são consideradas violações. Lamentavelmente, são minimizadas e banalizadas em um cenário cultural que carrega traços que favorecem a perpetuação das desigualdades de gênero entre homens e mulheres.

Talvez seja importante errarmos mais, tentando descobrir como conversar sobre sexualidade, como lidar com nossos próprios pudores e vergonhas. Precisamos aprender a lidar com desconcertos internos, deixando nossos dilemas, medos, inseguranças e tabus relacionados à sexualidade aparecerem. A omissão, que marca grande parte do funcionamento da sociedade da qual fazemos parte, já vem sendo a solução ineficaz apresentada.

Durante a pesquisa bibliográfica para esta dissertação, surpreendi-me com muitas pesquisas relacionadas com a temática. Uma delas indicou que um dos motivos importantes para a masturbação — além de aprender a lidar com o corpo, como o senso comum incessantemente inscreve — é lidar com conteúdos intrapsíquicos difíceis de operacionalizar, dadas as condições repressivas da sexualidade na cultura. Assim, masturbar-se também pode ser aprender a lidar com a culpa inscrita nas fantasias sexuais, por exemplo. Talvez precisemos nos masturbar com as palavras e aprender a transar conversações.

Há um risco grave, para o qual devemos estar atentos. Aprender a se comunicar sobre a sexualidade não significa dizer ao outro como ele deve vivenciar ou exercer a sexualidade. O limite, quando estamos lidando com a violência, é o direito alienado e/ou violado, que precisa ser restaurado. O risco de uma nova inscrição de poder sobre o 
corpo dos sujeitos sociais precisa estar sempre no horizonte do cuidado. Busquemos uma práxis orientada pelas necessidades das pessoas e não pelos nossos poderes. 


\section{REFERÊNCIAS BIBLIOGRÁFICAS}

Aguiar, L. H. M. (2009). Gênero e masculinidades follow-up de uma intervenção com homens autores de violência conjugal. Dissertação de Mestrado. Instituto de Psicologia, Universidade de Brasília.

Althusser, L., \& Albuquerque, J. A. G. (1992). Aparelhos ideológicos de Estado: nota sobre os aparelhos ideológicos de Estado. Rio de Janeiro: Graal.

Álvarez, C. D., Torralba, A. I., Torres, L. M., Tabernero, M. F. M., Vicario, B. P., Sanchez, J. F. P., Melguizo, P. P. S., Grande, M. D. P., Dominguez, F. I. R., \& Gomez, M. C. S. (2007). Patrones de masculinidad y feminidad asociados al ciclo de la violencia de género. Revista Investigación Educativa, 25, 187-218.

Andolfi, M., \& Angelo, C. (1989). Tempo e mito em terapia familiar. Porto Alegre: Artes Médicas.

de Andrade, V. R. P. (2005). A soberania patriarcal: o sistema de justiça criminal no tratamento da violência sexual contra a mulher. Seqüência: Estudos Jurídicos e Políticos, 26(50), 71-102.

Angelim, F. P. (2009). Mulheres vítimas de violência: dilemas entre a busca da intervenção do estado e a tomada de consciência. Tese de mestrado. Instituto de Psicologia, Universidade de Brasília. 
Angelim, F. P., \& Diniz, G. R. S. (2009). O pessoal torna-se político: o papel do Estado no monitoramento da violência contra as mulheres. Revista Psicologia Política, 9(18), 259-274.

Audi, C. A. F., Segall-Corrêa, A. M., Santiago, S. M., Andrade, M. D. G. G., \& PèrezEscamila, R. (2008). Violência doméstica na gravidez: prevalência e fatores associados. Revista de Saúde Pública, 42(5), 877-885.

Bellenzani, R., Blessa, C., \& Paiva, V. (2008). Scripts em cena: HIV e mercado sexual no contexto turístico. Psicologia em Estudo, 13(4), 653-662.

Belous, C. K., Timm, T. M., Chee, G., \& Whitehead, M. R. (2012). Revisiting the sexual genogram. The American Journal of Family Therapy, 40(4), 281-296.

Bozon, M. (2004). Sociologia da sexualidade. Rio de Janeiro: Editora FGV.

Brandão, E. R. (2006). Renunciantes de direitos? A problemática do enfrentamento público da violência contra a mulher: o caso da delegacia da mulher. Physis, 16(2), 207-31.

Brasil. (2006). Lei $n^{\circ} 11.340 / 06$, de 7 de agosto de 2006. Que coíbe a violência doméstica e familiar contra as mulheres. Brasília.

Bruschi, A., Paula, C. D., \& Bordin, I. A. S. (2006). Prevalência e procura de ajuda na violência conjugal física ao longo da vida. Revista de Saúde Pública, 40(2), 256-64. 
Bucher-Maluschke, J. S. N. F., \& Penso, M. A. (2008). Do transgeracional na perspectiva sistêmica à transmissão psíquica entre as gerações na perspectiva da psicanálise. Em: Penso, M. A., \& Liana, F. C. (Orgs.). A transmissão geracional em diferentes contextos: da pesquisa à intervenção (pp. 76-96). São Paulo: Summus.

Bueno, R. K., de Souza, S. A., Monteiro, M. A., \& Teixeira, R. H. M. (2013). Processo de Diferenciação dos Casais de suas Famílias de Origem. Psico, 44(1), pp. 16-25.

Butler, J. (2002). Cuerpos que importan. Sobre los límites materiales y discursivos del sexo. Buenos Aires, Paidós.

Butler, J. (2013). Problemas de gênero: feminismo e subversão da identidade. Rio de Janeiro: Editora Record.

Butler, J. (2014). Regulações de Gênero. Cadernos Pagu, 42, 249-274.

de Campos, C. H., \& de Carvalho, S. (2006). Violência doméstica e Juizados Especiais Criminais: análise a par Especiais Criminais: análise a partir do feminismo e do garantismo. Revista estudos feministas, 14(2), 409-422.

Carmona, M. (2011). ¿ Negocian las parejas su sexualidad? Significados asociados a la sexualidad y prácticas de negociación sexual. Revista estudos feministas, 19(3), 801821.

Carvalho, K. S. (2003). Análise semiótica da imagem da mulher e do homem nas propagandas da mídia impressa. Caderno de Semiótica Aplicada, 2(1), 35-45. 
Cavalcanti, L. F., Gomes, R., \& Minayo, M. D. S. (2006). Representações sociais de profissionais de saúde sobre violência sexual contra a mulher: estudo em três maternidades públicas municipais do Rio de Janeiro, Brasil. Cadernos de Saúde Pública, 22(1), 31-9.

Cerqueira, D; e Coelho, D.S.C. (2014). Estupro no Brasil: uma radiografia segundo os dados da Saúde. Brasília: IPEA.

Chambers, W. C. (2007). Oral sex: Varied behaviors and perceptions in a college population. Journal of Sex Research, 44(1), 28-42.

Colossi, P. M., \& Falcke, D. (2013). Gritos do silêncio: a violência psicológica no casal. Psico, 44(3), 310-318.

Cordeiro F. (2008). Negociando significados: coerção sexual em narrativas de jovens brasileiros. Dissertação de mestrado. Rio de Janeiro: Universidade do Estado do Rio de Janeiro.

Cordeiro, F., Heilborn, M. L., Cabral, C. D. S., \& Moraes, C. L. D. (2009). Entre negociação e conflito: gênero e coerção sexual em três capitais brasileiras. Ciência \& Saúde Coletiva, 14(4), 1051-1062.

Corsi, J. (2006). Violencia masculina en la pareja. Buenos Aires: Paidós. 
Crespo, C. (2011). À mesa com a família": Rituais familiares ao longo do ciclo de vida. In Famílias: Questões de desenvolvimento e intervenção. Porto: Livpsic.

Crespo, C. (2012). Families as contexts for attachment: Reflections on theory, research, and the role of family rituals. Journal of family theory \& review, 4(4), 290-298.

Crespo, C., Santos, S., Canavarro, M. C., Kielpikowski, M., Pryor, J., \& Féres-Carneiro, T. (2013). Family routines and rituals in the context of chronic conditions: A review. International Journal of Psychology, 48(5), 729-746.

Cunha, T.R.A. (2008). Violência conjugal: os ricos também batem. Publicatio UEPG 16(1), 167-176.

DaMatta, R. (2010). Tem pente aí? Reflexões sobre a identidade masculina. Enfoques, 9(1), 134-151.

Dantas-Berger, S. M., \& Giffin, K. (2005). A violência nas relações de conjugalidade: invisibilidade e banalização da violência sexual? Cadernos de Saúde Pública, 21(2), 417-425.

DataSenado (2013). Violência doméstica e familiar contra a mulher. Brasília: Subsecretaria de Pesquisa e Opinião da Secretaria de Transparência do Senado Federal. 
Deeke, L. P., Boing, A. F., de Oliveira, W. F., \& Coelho, E. B. S. (2009). A dinâmica da violência doméstica: uma análise a partir dos discursos da mulher agredida e de seu parceiro. Saúde e sociedade, 18(2), 248-258.

Diniz, G. (2009). O casamento contemporâneo em revista. In Féres-Carneiro, T. (Org.). Casal e família: permanências e rupturas (pp. 135-156). São Paulo: Casa do Psicólogo.

Diniz, G. R. S. (2011). Conjugalidade e violência: reflexões sobre uma ótica de gênero. In Féres-Carneiro, T. (Org.) Casal e família: conjugalidade, parentalidade e psicoterapia (pp. 11-26). São Paulo: Casa do Psicólogo.

Diniz, G. (2013). Até que a vida - ou a morte - os separe: análise de paradoxos das relações violentas. In Féres-Carneiro, T. (Org.) Casal e família: transmissão, conflito e violência (pp. 191-216). São Paulo: Casa do Psicólogo.

Diniz, G. R. S., \& Pondaag, M. C. M. (2004). Explorando significados do silêncio e do segredo nos contextos da violência doméstica. In Maluschke, G.; Bucher-Maluschke, J. S. N. F., \& Hermanns, K. (Orgs.). Direitos humanos e violência: desafios da ciência e da prática (pp. 171-185). Fortaleza: Fundação Konrad Adenauer.

Diniz, G. R. S., \& Pondaag, M. C. M. (2006). A face oculta da violência contra a mulher: o silêncio como estratégia de sobrevivência. In Almeida, A. M. O.; Santos, M. F. S.; Diniz, G. R. S., \& Trindade, Z. A. (Orgs.). Violência, exclusão social e desenvolvimento humano: estudos em representações sociais (pp. 233-259). Brasília: Editora Universidade de Brasília. 
Dutton, M. A., \& Goodman, L. A. (2005). Coercion in intimate partner violence: Toward a new conceptualization. Sex Roles, 52(11-12), 743-756.

Falcke, D., Oliveira, D. Z. D., Rosa, L. W. D., \& Bentancur, M. (2009). Violência conjugal: um fenômeno interacional. Contextos Clínicos, 2(2), 81-90.

Falcke, D., \& Wagner, A. (2014). A dinâmica familiar e o fenômeno da transgeracionalidade: definição de conceitos. In Wagner, A. (Org.). Como se perpetua a família?: a transmissão dos modelos familiares (pp. 25-46). Porto Alegre: EDIPUCRS.

Feix, V. (2011) Das formas de violência contra a mulher - artigo $7^{\circ}$ : Comentários. In de Campos, C. H. (Org.) Lei Maria da Penha comentada em uma perspectiva jurídicofeminista (pp. 201-214). Rio de Janeiro: Lumen Juris.

Féres-Carneiro, T. (2012). Aliança e sexualidade no casamento e no recasamento contemporâneo. Psicologia: Teoria e pesquisa, 3(3), 250-261.

Fleury, H. J., Abdo, C. H. N., \& Marra, M. M. (2005). Uma proposta psicoterápica para a mulher climatérica. Intervenções Grupais na Saúde. São Paulo: Agora.

Flick, U. (2009). Introdução à pesquisa qualitativa. Porto Alegre: Artmed. 
Fontanella, B. J. B., \& Gomes, R. (2015). Cuidados à saúde sexual de duas gerações de homens: permanências e volatilidades de roteiros e habitus. Ciência \& Saúde Coletiva, 20(1), 259-272.

Foucault, M. (2013). História da sexualidade I: a vontade de saber. Rio de Janeiro: Graal.

Fundação Perseu Abramo - FPA (2010). Mulheres brasileiras e gênero nos espaços público e privado. São Paulo: Núcleo de Opinião Pública da Fundação Perseu Abramo.

Gagnon, J., \& Simon, W. (2005). Sexual Conduct: The Social Sources of Human Sexuality. New Jersey: Aldine Transaction.

Gagnon, J. (2006). Uma interpretação do desejo: ensaios sobre o estudo da sexualidade. Rio de Janeiro: Garamond.

Galli, R. A. (2013). Roteiros sexuais de transexuais e travestis e seus modos de envolvimento sexual-afetivo. Dissertação de Mestrado, Faculdade de Filosofia, Ciências e Letras de Ribeirão Preto, Ribeirão Preto.

Giacomozzi, A. I., \& Camargo, B. V. (2004). Eu confio no meu marido: estudo da representação social de mulheres com parceiro fixo sobre prevenção da AIDS. Psicologia: teoria e prática, 6(1), 31-44.

Goldenberg, M. (2005). Dominação masculina e saúde: usos do corpo em jovens das camadas médias urbanas. Ciência e Saúde Coletiva, 10(1), 91-96. 
Guedes, M. E. F., \& Moreira, A. C. G. (2010). Gênero, saúde e adolescência: uma reflexão a partir do trabalho com a violência doméstica e sexual. MudançasPsicologia da Saúde, 17(2), 79-91.

Guimarães, F. (2009). “Mas ele diz que me ama...”: impacto da história de uma vítima na vivência de violência conjugal de outras mulheres. Dissertação de mestrado. Instituto de Psicologia, Universidade de Brasília.

Guimarães, R. (2011). Poder judiciário e violência contra a mulher: aplicação da Lei Maria da Penha aos conflitos domésticos e familiares. Dissertação de mestrado. Instituto de Ciências Sociais, Universidade de Brasília.

Heilborn, M. L. (2006). Entre as tramas da sexualidade brasileira. Revista estudos feministas, 14(1), 43-59.

Heilborn, M. L., Aquino, E. M., Bozon, M., \& Knauth, D. R. (2006). O aprendizado da sexualidade. Reprodução e trajetórias sociais de jovens brasileiros. Rio de Janeiro: Garamond.

Hirigoyen, M. F. (2006). A violência no casal: da coação psicológica à agressão física. Rio de Janeiro: Bertrand Brasil.

Imber-Black, E. (2002) Segredos na família e na terapia familiar: uma visão geral. In ImberBlack, E. (Org.). Os segredos na família e na terapia familiar (pp. 15-39). Porto Alegre: Artmed. 
Imber-Black, E. (2006a). Motivos rituales en las familias y en la terapia familiar. In Imber-Black, E., Roberts, J.; Whiting, R. A. (Orgs.). Rituales terapeuticos y ritos en la familia (pp. 73-112). Barcelona: Gedisa.

Imber-Black, E. (2006b). Rituales normativos y terapêuticos em la terapia de parejas. Em Imber-Black, E., Roberts, J.; Whiting, R. A. (Orgs.). Rituales terapeuticos y ritos en la familia (pp. 143-165). Barcelona: Gedisa.

Instituto Avon / Data Popular. (2014). Violência contra a mulher: o jovem está ligado?. Instituto Avon.

Jablonski, B. (2007). O cotidiano do casamento contemporâneo: a difícil e conflitiva divisão de tarefas e responsabilidades entre homens e mulheres. In Féres-Carneiro, T. (Org.) Família e casal: saúde, trabalho e modos de vinculação (pp. 203-228). São Paulo: Casa do Psicólogo.

Johnson, M. P., \& Leone, J. M. (2005). The differential effects of intimate terrorism and situational couple violence findings from the national violence against women survey. Journal of family issues, 26(3), 322-349.

Johnson, J. M. (2006). Violence and Abuse in Personal Relationships: Conflict, Terror, and Resistance in Intimate Partnerships. In The Cambridge Handbook of Personal Relationships (pp. 557-578). New York: Cambridge University Press. 
Junqueira, L. C. U. (2014). A roteirização da sexualidade por enfermeiras que cuidam de pacientes com câncer de mama. Tese de Doutorado, Faculdade de Filosofia, Ciências e Letras de Ribeirão Preto, Ribeirão Preto.

Kronbauer, J. F. D., \& Meneghel, S. N. (2005). Perfil da violência perpetrada por companheiro. Revista de Saúde Pública, 39(5), 695-701.

Lamoglia, C.V.A., \& Minayo, M.C.S. (2009). Violência conjugal, um problema social e de saúde pública: Estudo em uma delegacia do interior do Rio de Janeiro. Ciência \& Saúde Coletiva, 14, 595-604.

de Lauretis, T. (1994) A tecnologia do gênero. In H. B. Hollanda (Org.), Tendências e Impasses: o feminismo como crítica da cultura (pp. 206-242). Rio de Janeiro: Rocco.

de Lauretis, T. (2007). Figures of resistance: Essays in feminist theory. Chicago: University of Illinois Press.

Leone, J. M., Johnson, M. P., \& Cohan, C. L. (2007). Victim help seeking: Differences between intimate terrorism and situational couple violence. Family Relations, 56(5), 427-439.

Levy, L., \& Gomes, I. C. (2008). Relação conjugal, violência psicológica e complementaridade fusional. Psicologia Clínca, 20(2), 163-172.

Lindner, S. R., Coelho, E. B. S., Bolsoni, C. C., Rojas, P. F., \& Boing, A. F. (2015). Prevalência de violência física por parceiro íntimo em homens e mulheres de 
Florianópolis, Santa Catarina, Brasil: estudo de base populacional em. Cadernos de Saúde Pública, 31(4), 815-826.

Lisboa, A. V., Féres-Carneiro, T., \& Jablonski, B. (2007). Transmissão intergeracional da cultura: um estudo sobre uma família mineira. Psicologia em estudo, 12(1), 5159.

Lottes, I. L., \& Weinberg, M. S. (1997). Sexual coercion among university students: A comparison of the United States and Sweden. Journal of Sex Research, 34(1), 67-76.

Machado, L. Z. (1998). Masculinidade, sexualidade e estupro: as construções da virilidade. Cadernos Pagu, 11, 231-273.

Machado, L. Z. (2004). Masculinidades e violências: gênero e mal-estar na sociedade contemporânea. In Schpun, M. R. (Org.). Masculinidades (pp. 35-78). São Paulo: Bomtempo Editorial.

Magalhães, M. L., de Araújo, D. C., \& Schemes, C. (2013). Queixosas e valentes: as mulheres e a visibilidade da violência cotidiana. Revista Estudos Feministas, 21(3), 839-859.

McGoldrick, M., \& Gerson, R. (1995). Genetogramas e o ciclo de vida familiar. In Carter, B., \& McGoldrick, M. (Orgs.) As mudanças no ciclo de vida familiar: uma estrutura para a terapia familiar (pp. 144-166). Porto Alegre: Artmed Editora. 
McGoldrick, M., Gerson, R., \& Petry, S. (2012). Genogramas: avaliação e intervenção familiar. Porto Alegre: Artmed Editora.

McGoldrick, M., Loonan, R., \& Wohlsifer, D. (2011). Sexualidade e Cultura. In Leiblum, S. R. (Org.) Princípios e prática da terapia sexual (pp. 395-418). São Paulo: Roca.

Minayo, M. C. S. (2010). O desafio do conhecimento: pesquisa qualitativa em saúde. São Paulo: Editora Hucitec.

Monteiro, A. C. (2014). Autores de violência doméstica e familiar: um estudo sobre um grupo de reflexão no Paranoá/DF. Dissertação de mestrado. Instituto de Ciências Sociais: Universidade de Brasília.

Monteiro, C. F. S., \& Souza, I. E. O. (2007). Vivência da violência conjugal: fatos do cotidiano. Texto \& contexto enfermagem, 16(1), 26-31.

Moraes, C. L., Arana, F. D. N., \& Reichenheim, M. E. (2010). Violência física entre parceiros íntimos na gestação como fator de risco para a má qualidade do prénatal. Revista saúde pública, 44(4), 667-76.

Moraes, C. L. D., Cabral, C. S., \& Heilborn, M. L. (2006). Magnitude e caracterização de situações de coerção sexual vivenciadas por jovens de três grandes capitais brasileiras: Porto Alegre, Rio de Janeiro e Salvador. Caderno de Saúde Pública, 22, 1493-504. 
Moraes, C. L., Hasselmann, M. H., \& Reichenheim, M. E. (2002). Adaptação transcultural para o português do instrumento" Revised Conflict Tactics Scales (CTS2)" utilizado para identificar violência entre casais. Caderno de Saúde Pública, 18(1), 163-76.

Moura, L. B. A., Lefevre, F., \& Moura, V. (2012). Narrativas de violências praticadas por parceiros íntimos contra mulheres. Ciência \&. saúde coletiva, 17(4), 1025-1035.

Muehlenhard, C. L., \& Peterson, Z. D. (2005). Wanting and not wanting sex: The missing discourse of ambivalence. Feminism \& Psychology, 15(1), 15-20.

Narvaz, M. G., \& Koller, S. H. (2006). Mulheres vítimas de violência doméstica: compreendendo subjetividades assujeitadas. Psico, 37(1), 7-13.

Negreiros, T. C. D. G. M., \& Féres-Carneiro, T. (2004). Masculino e feminino na família contemporânea. Estudos e pesquisas em psicologia, 4(1), 34-47.

Okin, S. M. (2008). Gênero, o público e o privado, o público e o privado. Revista estudos feministas, 16(2), 305-332.

de Oliveira, A. F. P. L., Schraiber, L. B., França-Junior, I., Ludermir, A. B., Portella, A. P., Diniz, C. S., Couto, M. T., \& Valença, O. (2009). Fatores associados à violência por parceiro íntimo em mulheres brasileiras. Revista de Saúde Pública, 43(2), 299311. 
Paiva, V. (2000). Fazendo arte com a camisinha: sexualidades jovens em tempos de aids. São Paulo: Summus Editorial.

Paiva, V. (2006). Analyzing sexual experiences through 'scenes': A framework for the evaluation of sexuality education. Sex Education, 4(5), 345-359.

Papero, D. V. (2014). Assisting the Two-person System: An Approach Based on the Bowen Theory. Australian and New Zealand Journal of Family Therapy, 35(4), 386397.

Parker, R. G. (2010). Reinventing sexual scripts: Sexuality and social change in the twenty-first century. Sexuality Research and Social Policy, 7(1), 58-66.

Pilecco F. B., Knauth D. R., Vigo Á. (2011) Aborto e coerção sexual: o contexto de vulnerabilidade entre mulheres jovens. Caderno de Saúde Pública, 27(3), 427-39.

Pondaag, M. C. M. (2009). Sentidos da violência conjugal: a perspectiva de casais. Tese de doutorado. Instituto de Psicologia, Universidade de Brasília.

Ravazzola, M. C. (2005). Historias infames: los maltratos em las relaciones. Buenos Aires: Paidós.

Razera, J., Cenci, C. M. B., \& Falcke, D. (2014). Violência doméstica e transgeracionalidade: um estudo de caso. Revista de Psicologia da IMED, 6(1), 4751. 
Renner, L. M., \& Slack, K. S. (2006). Intimate partner violence and child maltreatment: Understanding intra-and intergenerational connections. Child Abuse \& Neglect, 30(6), 599-617.

Ribeiro, M. M., Rosso, A. J., \& Martins, R. B. (2004). Violência doméstica: a realidade velada. Revista Brasileira de Estudos Pedagógicos, 85(209/210/211), pp. 114-125.

Ribeiro, M. A., \& Bareicha, I. C. (2008). Investigando a transgeracionalidade da violência intrafamiliar. Em: Penso, M. A., \& Liana, F. C. (orgs.). Transmissão geracional em diferentes contextos: da pesquisa a intervenção (pp.251-281). São Paulo: Summus.

Risen, C. B. (2005). Listening to sexual stories. Handbook of clinical sexuality for mental health professionals (pp. 3-18). New York: Brunner-Routhledge.

Roberts, J. (2006). Encuadre: definición, funciones y tipologia de los rituales. Em ImberBlack, E., Roberts, J.; Whiting, R. A. (Orgs.). Rituales terapeuticos y ritos en la familia (pp. 25-72). Barcelona: Gedisa.

Rodrigues, C. (2010). Diferença sexual, direitos e identidade: um debate. Cadernos pagu, 34, 209-233.

da Rosa, A. G., Boing, A. F., Büchele, F., de Oliveira, W. F., \& Coelho, E. B. S. (2008). A violência conjugal contra a mulher a partir da ótica do homem autor da violência. Saúde e sociedade, 17(3), 152-160. 
Rosa, L. W. D., \& Falcke, D. (2014). Violência conjugal: compreendendo o fenômeno. Revista da SPAGESP, 15(1), 17-32.

Saffioti, H. I. B. (1999). Já se mete a colher em briga de marido e mulher. Perspectiva, 13(4), 82-91.

Saffioti, H. I. (2001). Contribuições feministas para o estudo da violência de gênero. Cadernos Pagu, 16, 115-136.

Saffioti, H. (2003). Violência estrutural e de gênero - Mulher gosta de apanhar. Programa de Prevenção, assistência e combate à violência contra a mulher. Diálogos sobre a violência doméstica e de gênero: construindo políticas públicas. Brasília: Secretaria Especial de Políticas para as Mulheres.

Saffioti, H. I. B. (2007). Gênero, patriarcado, violência. São Paulo: Fundação Perseu Abramo.

Santos, C. M., \& Izumino, W. P. (2005). Violência contra as mulheres e violência de gênero: notas sobre estudos feministas no Brasil. Estúdios Interdisciplinarios de América Latina y El Caribe, 16(1), 47-64.

Sarti, C. (2009). Corpo, violência e saúde: a produção da vítima. Sexualidad, Salud y Sociedad-Revista Latinoamericana, 1, 89-103.

Sarti, C. (2011). A vítima como figura contemporânea. Caderno CRH, 24(61), 51-61. 
Schraiber, B. L., Oliveira, A. F. L. D., França-Júnior, I. F., Diniz, S., Portella, A. P., Ludermir, A. B., Valença, O., \& Couto, M. T. (2007). Prevalência da violência contra a mulher por parceiro íntimo em regiões do Brasil. Revista de Saúde Pública, 41(5), 797-807.

Schraiber, L. B., Oliveira, A. F. P., \& Junior, I. F. (2008). Violência sexual por parceiro íntimo entre homens e mulheres no Brasil urbano, 2005. Revista de Saúde Pública, 42(1), 127-137.

Schraiber, L. B., Oliveira, A. F. P. L., Portella, A. P., \& Menicucci, E. (2009). Violência de gênero no campo da Saúde Coletiva: conquistas e desafios. Ciência \& Saúde Coletiva, 14(4), 1019-27.

Scott, J. W. (1995). Gênero: uma categoria útil de análise histórica. Educação e Realidade, 20(2), 71-99.

Scott, J. W. (1998). A invisibilidade da experiência. Projeto História. Revista do Programa de Estudos Pós-Graduados de História, 16, 297-325.

Scott, J. W., \& Navarro-Swain, T. (2011) Entrevista con la profesora Joan W. Scott. Anuario de Hojas de Warmi, 16.

Scott, J. W. (2011). The fantasy of feminist history . Durham, NC: Duke University Press.

Scott, J. W. (2011). Género:¿ Todavía una categoría útil para el análisis?.Revista La Manzana de la Discordia, 6(1), 95-101. 
Segato, R. L. (2003). Las Estructuras Elementales de la Violencia. Buenos Aires: Prometeo.

Silva, D. M. D. C. F., \& Muro, E. (2014). O pensamento contrafactual e a atribuição de culpa a vítimas de violação em cenários de stranger e acquaintance rape. Dissertação de mestrado. Lisboa: Instituto Universitário de Ciências Psicológicas, Sociais e da Vida.

da Silva, L. L., Coelho, E. B. S., \& de Caponi, S. N. C. (2007). Violência silenciosa: Violência psicológica como condição da violência física doméstica. Interface Comunicação, Saúde, Educação, 11, 93-103.

Simon, W., \& Gagnon, J. H. (1984). Sexual scripts. Society, 22(1), 53-60.

Simon, W., \& Gagnon, J. H. (1986). Sexual scripts: Permanence and change. Archives of sexual Behavior, 15(2), 97-120.

Smit, R. (2011). Maintaining Family Memories through Symbolic Action: Young Adults' Perceptions of Family Rituals in Their Families of Origin. Journal of Comparative Family Studies, 42(3), 355-367.

Soares, B. M. (1999). Mulheres invisíveis: violência conjugal e as novas políticas de segurança. Rio de Janeiro: Civilização Brasileira. 
de Souza, E. M., \& Carrieri, A. P. (2010). A analítica queer e seu rompimento com a concepção binária de gênero. Revista de Administração Mackenzie, 11(3), 46-70.

Souza, V. R. O. G. D. (2009). Metáforas do universo lexical português e italiano das zonas erógenas: ânus, nádegas, pênis, seios, testículos e vulva. Tese de doutorado. São José do Rio Preto: UNESP.

Stone, N., Hatherall, B., Ingham, R., \& McEachran, J. (2006). Oral sex and condom use among young people in the United Kingdom. Perspectives on sexual and reproductive health, 38(1), 6-12.

Vertamatti, M. A. F., Abreu, L. C. D., Drezett, J., Valenti, V. E., \& Barbosa, C. P. (2013). Tempo decorrido entre agressão sexual e a chegada aos serviços de saúde no Brasil. Revista brasileira de crescimento e desenvolvimento humano, 23(1), 46-51.

Vieira, E. M., Perdona, G. D. S. C., \& Santos, M. A. D. (2011). Fatores associados à violência física por parceiro íntimo em usuárias de serviços de saúde. Revista de Saúde Pública, 45(4), 730-7.

Wagner, A. (2014). Como se perpetua a família. Porto Alegre: EDIPUCRS.

Waiselfisz, J. J. (2015). Mapa da violência 2015: homicídio de mulheres no Brasil. Brasília: Secretaria Especial de Políticas para as Mulheres.

Walker, L. E. (2009). The battered woman Syndrome. New York: Springer. 
Welter-Enderlin, R. (2002). Segredos dos casais e terapia conjugal. In Imber-Black, E. (org). Os segredos na família e na terapia familiar (pp. 57-75). Porto Alegre: Artmed.

Whiting, R. A. (2006). Pautas para la elaboración de rituales terapéuticos. Em ImberBlack, E., Roberts, J.; Whiting, R. A. (Orgs.). Rituales terapeuticos y ritos en la familia (pp. 113-139). Barcelona: Gedisa.

Yin, R. K. (2010) Estudo de Caso: planejamento e métodos. Porto Alegre: Bookman.

Zampieri, A. M. F. (2004). Erotismo, sexualidade, casamento e infidelidade: sexualidade conjugal e prevenção do HIV e da Aids. São Paulo: Editora Agora. 
ANEXOS 


\section{Anexo 1 - Instrumentos}

A - Questionário sociodemográfico

\section{Dados Demográficos}

\section{Identificação}

1. Idade (anos) do participante:

2. Qual a sua cor/etnia?

3. Cidade/estado onde você nasceu:

4. Cidade/estado onde você mora atualmente:

5. Há quanto tempo você mora nessa cidade?

6. Que motivo(s) levou você a mudar para essa cidade:

7. Você tinha família e/ou parentes aqui quando mudou para essa cidade?

( ) Não ( ) Sim Quais:

8. Qual foi seu trabalho quando você chegou?

Estado civil:( ) solteiro ( ) vive com companheiro/a ( ) casado ( ) separado ( )viúvo

9. Tem filhos ( ) Não ( ) Sim - Quantos:

10. Você possui religião? ( ) Não ( ) Sim

Qual:

11. Com que frequência você vai a sua igreja?

12. Qual a importância da religião em sua vida?

\section{Condição de Moradia}

13. Local onde você mora - bairro:

14. Tipo de Residência

( ) casa ( )apartamento ( ) chácara ( ) barraco em lote ( ) outro:

15. A moradia é:

( ) alugada ( ) própria ( ) cedida pela família ( ) cedida por amigos ( ) emprestada outro:

16. Se alugada, valor do aluguel:

17. Você mora:

( ) sozinho

( ) com família - marido/esposa/companheiro(a)

( ) com família - marido/esposa/companheiro(a) e filhos

( ) com família - marido/esposa/companheiro(a), filhos e filhos de criação

( ) com marido/esposa/companheiro(a), filhos e seus parentes (pai-mãe-irmãos)

( ) com marido/esposa/companheiro(a), filhos e parentes de seu marido/esposa (paimãe-irmãos)

( ) com amigos/as ( ) com vizinhos ( )outro: 
18. Quantas pessoas moram em sua casa (contando com você)? pessoas.

\section{Educação}

19. Em relação ao estudo marque uma das opções abaixo:

( ) não estudei*

( ) básico, qual série

( ) fundamental, qual série

( ) médio, qual série

( ) Curso técnico. Qual curso?

Trabalha na área? ( ) Não ( ) Sim

( ) Universidade/faculdade. Curso: Ano de conclusão:

*Obs: Favor comentar - Por que você não estudou? Você se arrependeu de não ter estudado? O que teria feito diferente?

\section{Situação econômica}

20. Você tem alguma atividade que gera renda em casa? ( ) Não ( ) Sim

21. O que você faz?

22. Quanto ganha?

23. Esse dinheiro você usa para que?

24. Você tem alguma atividade que gera renda fora de casa?

25. O que você faz?

26. Quanto ganha?

27. Esse dinheiro você usa para que?

28. Renda pessoal em salário mínimo (SM):

( ) menos de 1 SM ( ) de 1 a 2 SM ( ) de 2 a 3 SM ( ) de 3 a 4 SM ( ) acima de 4 SM Observação: o valor do salário mínimo atual é R $\$ 788,00$

29. Você tem ou já teve carteira assinada? ( ) Sim ( ) Não

30. Caso sim, quando?

31. Em que você trabalha/trabalhava?

32. Se você parou de trabalhar, por que você deixou esse trabalho?

33. Atualmente você está desempregado(a)? ( ) Não ( ) Sim

34. Por quê?

35. Caso você esteja desempregado(a), quais trabalhos você já teve?

36. Seu companheiro(a) te pediu para sair do trabalho? ( ) Não ( ) Sim

37. Por quê?

38. Você pretende voltar a trabalhar? ( ) Não ( ) Sim

39. Por quê? 
40. Você é dependente economicamente de alguém?
( ) companheiro(a)
( ) família - quem?
( ) bolsa do governo - qual bolsa?
( ) pensão de outro companheiro(a)
( ) outro tipo de pensão
( ) outros

\section{Qual a principal fonte de sustento do seu lar:}

( ) Salário não fixo do participante da pesquisa

( ) Salário mensal fixo do participante da pesquisa

( ) Salário não fixo do companheiro(a)

( ) Salário mensal fixo do companheiro(a)

( ) Ajuda da família do companheiro(a)

( ) Ajuda da sua família

( ) renda de aluguel

( ) Assistência social - indique:

( ) Outros:

42. Apresentamos abaixo uma lista contendo 12 itens. Para cada um, marque um $X$ na coluna que indica se existem ou não em sua casa e quantos:

\begin{tabular}{|l|l|l|l|}
\hline ITENS & TEM & Quantos & NÃO TEM \\
\hline Aparelho de DVD & & & \\
\hline Aparelho de BluRay & & & \\
\hline Aparelho de som com CD & & & \\
\hline Automóvel & & & \\
\hline Celular & & & \\
\hline Computador & & & \\
\hline Fogão & & & \\
\hline Geladeira & & & \\
\hline Internet por assinatura & & & \\
\hline Linha de telefone (fixo) & & & \\
\hline Máquina de lavar roupa & & & \\
\hline Microondas & & & \\
\hline Tanquinho & & & \\
\hline Televisão & & & \\
\hline TV por assinatura & & & \\
\hline
\end{tabular}


B - Entrevista 1 - O genograma do casal

Informações demográficas e interacionais a serem ativamente buscadas para a construção do genograma, o mapa estrutural trigeracional da família do casal:

- Membros familiares da geração do casal até a dos avós e respectivas moradias

- Datas (anos) de nascimento, casamento, separação, doença (tipo) e morte (causa)

- Origem étnica, de classe e religiosa;

- Eventuais mudanças de classe através da educação, renda ou casamento;

- Práticas religiosas atuais e mudanças de congregação/religião;

- Ocupação e educação;

- Situação dos relacionamentos atuais (proximidade, conflito, rompimento)

Questões norteadoras subsequentes à montagem básica do genograma:

- O que é ser mulher para vocês?

- O que vocês aprenderam com suas mães, suas avós ou outras mulheres da família sobre o que é ser mulher?

- O que é ser homem para vocês?

- O que vocês aprenderam com seus pais, seus avôs ou outros homens da família sobre o que é ser homem?

- O que vocês aprenderam na família de vocês sobre quais são as obrigações das mulheres?

- Vocês estão de acordo com essas obrigações?

- O que vocês aprenderam na família de vocês sobre quais são as obrigações dos homens?

- Vocês estão de acordo com essas obrigações?

- Se vocês fossem comparar a vida dos seus pais e a de vocês, o que mudou para melhor? E para pior? Quais dificuldades vocês têm que eles não tinham? 
C - Entrevistas 2 e 3 - O genograma sexual

Questões norteadoras para o processo de construção do genograma sexual

- Alguma vez vocês já conversam sobre sexo/sexualidade?

- Como a sexualidade ou intimidade era conversada? Controlada? Ensinada? As gerações anteriores eram diferentes nas mensagens que davam?

- Quem da sua família era mais aberto sexualmente? Emocionalmente? Fisicamente? Quem era mais fechado? Como isso afetou os outros membros da família?

- Havia segredos na sua família com relação a intimidade, sexo ou abuso? (incesto? Outros abusos sexuais? Gravidezes indesejadas? Casos extraconjugais? Gravidez antes do casamento? Abortos? Casamento de primos?)

- Como lidavam com material erótico, como livros ou revistas com conteúdo sexual? E pornografia? E como você lida?

- Os casos extraconjugais ou visitas a prostitutas eram tolerados ou discutidos? Como são tratados esses assuntos hoje no seu relacionamento?

- Como você acha que os relacionamentos sexuais ou íntimos dos membros da sua família foram influenciados pela sua etnia? Pobreza? Sucesso? Gênero? Orientação sexual? Imigração? Dificuldades de linguagem? Raça?

- Como os valores de sua religião ou formação cultural influenciam a sua visão de sexualidadade e intimidade? Existem aspectos em que a sua visão é diferente?

- Como você gostaria de mudar as mensagens que você dá para a próxima geração em relação à sexualidade e intimidade a partir das mensagens que você recebeu de sua família?

- Em que as normas da sua família eram similares ou diferentes das normas na família de origem do seu parceiro? Como você acha que essas diferenças podem afetar o seu relacionamento sexual ou íntimo?

- Como você acha que vocês se saíram como casal administrando as diferenças? A que valores compartilhados vocês chegaram sobre as questões sexuais?

- Como vocês conversam/negociam sobre o que um quer e o outro não quer durante as relações sexuais?

- O que você acha que mudaria na vida de um casal se eles parassem de fazer sexo?

- O sexo pode ajudar os casais em momentos difíceis? Já ajudou vocês? 
D - Entrevistas 4 e 5

Questões para entrevistas individuais que permeiam casamento, violência e sexualidade

- O que é casamento para você?

- Quais são os pontos positivos do seu casamento? E os negativos?

- Você guarda alguma lembrança de ter sofrido algum tipo de violência em sua vida? Qual tipo? (Física? Verbal? Psicológica? Ameaça? Abuso sexual? Outro?) Quem cometeu? Qual era sua idade mais ou menos?

- Como você lidou com essa situação?

- Você já praticou algum ato de violência? Qual tipo? Contra quem? Que motivo levou você a praticar violência?

- Que motivos você acha que levam um companheiro a cometer violência contra a mulher?

- O que significa fazer sexo na vida de um casal? Qual é o motivo que faz os casais terem relações sexuais?

- Como foram as suas primeiras experiências sexuais? Como se sentiu a respeito na época? E agora?

- Como foram as suas piores experiências sexuais?

- Como foram as suas melhores experiências sexuais?

- O que provoca o interesse ou a vontade de fazer sexo? O que pode acontecer que faria você não querer fazer sexo?

- Como era o sexo no início do casamento?

- Como é o sexo agora? O sexo já mudou? Ele já foi diferente?

- O que você acha que está por trás de o/a seu/sua marido/esposa querer fazer sexo com você?

- Quais são os pensamentos e sentimentos que experimenta cada um antes da atividade sexual? Durante a atividade sexual? Depois da atividade sexual?

- Se tivesse que mudar as atividades sexuais, como você mudaria?

- Alguma vez você fez sexo sem a sua vontade/contra a vontade dele(a)?

- Quais desses conteúdos você já compartilhou com seu cônjuge? Que questões você não se sente à vontade para tratar em uma entrevista conjunta? (Essa pergunta tem a intenção específica de explorar conteúdos confidenciais pessoais para preservar o bem-estar do participante, pois ocorrerá uma entrevista de fechamento com o casal em que aquilo que for apontado aqui não será tratado.) 
E - Entrevista de fechamento da coleta de dados com o casal

Questões para reflexão final da coleta de dados

- Vocês acham que quais foram os pontos negativos dos encontros anteriores? E os positivos?

- Algum dos assuntos tratados surpreendeu vocês? Algo foi perguntado sobre o qual vocês nunca tinham pensado ou falado?

- Muitas vezes é difícil falar sobre a nossa intimidade ou sobre a nossa sexualidade. Vocês tiveram alguma dificuldade com algo que foi tratado durante os encontros anteriores? Como isso afetou vocês?

- Algum dos assuntos tratados causou vergonha ou desconforto? Com qual intensidade? Isso ainda te afeta?

- Algum dos assuntos tratados foi motivo de dificuldades entre vocês? Conflitos, discussões ou brigas? Como vocês resolveram essas dificuldades?

- Existe alguma outra dificuldade não conversada que vocês gostariam de falar? 
F - Revised Conflict Tatic Scales (CTS-2). Traduzido por Moraes e col. (2002).

“Os casais têm maneiras diferentes de tentar resolver suas diferenças. Mesmo que um casal se relacione bem, tem vezes em que um discorda do outro, se chateia com o outro, discutem e se agridem apenas porque estão de mau humor, cansados ou por outra razão qualquer”.

"Por favor, eu gostaria de saber se você e seu companheiro fizeram cada uma das coisas que serão perguntadas a seguir".

Instruções para preenchimento:

Leia cada uma das questões a seguir e assinale a resposta correspondente.

Caso assinale "Sim", tente estimar o número de vezes que aconteceu.

1a Você mostrou que se importava com ele mesmo que vocês estivessem discordando?

( ) Não ( ) Sim Quantas vezes? ( ) Isso aconteceu somente em outras relações

1b Seu companheiro(a) mostrou que se importava com você mesmo que vocês estivessem discordando?

( ) Não ( ) Sim Quantas vezes? ( ) Isso aconteceu somente em outras relações

2a Você explicou para seu companheiro(a) o que você não concordava com ele?

( ) Não ( ) Sim Quantas vezes? ( ) Isso aconteceu somente em outras relações

2b Seu companheiro(a) explicou para você o que ele não concordava com você?

( ) Não ( ) Sim Quantas vezes? ( ) Isso aconteceu somente em outras relações

3a Você insultou ou xingou o seu companheiro(a)?

( ) Não ( ) Sim Quantas vezes?____ ( ) Isso aconteceu somente em outras relações

3b Seu companheiro(a) fez isso com você?

( ) Não ( ) Sim Quantas vezes?___ （ ） Isso aconteceu somente em outras relações

4a Você jogou alguma coisa no seu companheiro(a) que poderia machucá-lo?

( ) Não ( ) Sim Quantas vezes?____ ( ) Isso aconteceu somente em outras relações

4b Seu companheiro(a) fez isso com você?

( ) Não ( ) Sim Quantas vezes?____ （ ） Isso aconteceu somente em outras relações

5a Você torceu o braço do seu companheiro(a) ou puxou o cabelo dele?

( ) Não ( ) Sim Quantas vezes?____ ( ) Isso aconteceu somente em outras relações

5 b Seu companheiro(a) fez isso com você?

( ) Não ( ) Sim Quantas vezes?____ （ ） Isso aconteceu somente em outras relações

6a Você teve uma torção, contusão, "mancha roxa" ou pequeno corte por causa de uma briga com seu companheiro(a)? ( ) Não ( ) Sim Quantas vezes? relações ( ) Isso aconteceu somente em outras

6b Seu companheiro(a) teve uma torção, contusão, "mancha roxa" ou pequeno corte por causa de uma briga com você?

( ) Não ( ) Sim Quantas vezes? ( ) Isso aconteceu somente em outras relações

7a Você mostrou que respeitava os pontos de vista e os sentimentos dele?

( ) Não ( ) Sim Quantas vezes? ( ) Isso aconteceu somente em outras relações

7b Seu companheiro(a) mostrou que respeitava os seus pontos de vista e os seus sentimentos?

( ) Não ( ) Sim Quantas vezes? ( ) Isso aconteceu somente em outras relações

8a Você obrigou o seu companheiro(a) a fazer sexo sem usar camisinha?

( ) Não ( ) Sim Quantas vezes?____ ( ) Isso aconteceu somente em outras relações

8 b Seu companheiro(a) fez isso com você?

( ) Não ( ) Sim Quantas vezes?____ （ ） Isso aconteceu somente em outras relações 
9a Você deu um empurrão no seu companheiro(a)?

( ) Não ( ) Sim Quantas vezes? ( ) Isso aconteceu somente em outras relações

9b Seu companheiro(a) fez isso com você?

( ) Não ( ) Sim Quantas vezes?____ ( ) Isso aconteceu somente em outras relações

10a Você usou de força como, por exemplo, segurar ou bater nele ou usar uma arma, para obrigar o seu companheiro(a) a fazer sexo oral ou anal com você?

( ) Não ( ) Sim Quantas vezes?

( ) Isso aconteceu somente em outras relações

10b Seu companheiro(a) fez isso?

( ) Não ( ) Sim Quantas vezes? ( ) Isso aconteceu somente em outras relações

11a Você usou uma faca ou arma contra o seu companheiro(a)?

( ) Não ( ) Sim Quantas vezes? ( ) Isso aconteceu somente em outras relações

11 b Seu companheiro(a) fez isso com você?

( ) Não ( ) Sim Quantas vezes?____ ( ) Isso aconteceu somente em outras relações

12a Você desmaiou ao levar uma pancada na cabeça durante uma briga com o seu companheiro(a)?

( ) Não ( ) Sim Quantas vezes? ( ) Isso aconteceu somente em outras relações

12b Seu companheiro(a) desmaiou ao levar uma pancada na cabeça durante uma briga com você?

( ) Não ( ) Sim Quantas vezes? ( ) Isso aconteceu somente em outras relações

13a Você chamou o seu companheiro(a) de gordo/a, feio/a ou alguma coisa parecida? ( ) Não ( ) Sim Quantas vezes? ( ) Isso aconteceu somente em outras relações

13b Seu companheiro(a) chamou você de gorda/o, feia/o ou alguma coisa parecida? ( ) Não ( ) Sim Quantas vezes?____ （ ) Isso aconteceu somente em outras relações

14a Você deu um murro ou acertou o seu companheiro(a) com alguma coisa que pudesse machucar?

( ) Não ( ) Sim Quantas vezes? ( ) Isso aconteceu somente em outras relações

14b Seu companheiro(a) fez isso com você?

( ) Não ( ) Sim Quantas vezes? ( ) Isso aconteceu somente em outras relações

15a Você destruiu alguma coisa que pertencia ao seu companheiro(a) de propósito? ( ) Não ( ) Sim Quantas vezes? ( ) Isso aconteceu somente em outras relações

15b Seu companheiro(a) fez isso? ( ) Não ( ) Sim Quantas vezes? ( ) Isso aconteceu somente em outras relações

16a Você foi a um médico ou serviço de saúde por causa de uma briga com seu companheiro?

( ) Não ( ) Sim Quantas vezes? ( ) Isso aconteceu somente em outras relações

16b Seu companheiro(a) foi ao médico ou algum serviço de saúde por causa de uma briga com você? ( ) Não ( ) Sim Quantas vezes? ( ) Isso aconteceu somente em outras relações

17a Você sufocou ou estrangulou seu companheiro(a)?

( ) Não ( ) Sim Quantas vezes? ( ) Isso aconteceu somente em outras relações

17b Seu companheiro(a) fez isso com você?

( ) Não ( ) Sim Quantas vezes?____ （ ） Isso aconteceu somente em outras relações

18a Você gritou ou berrou com o seu companheiro(a)?

( ) Não ( ) Sim Quantas vezes?____ （ ) Isso aconteceu somente em outras relações

18b Seu companheiro(a) fez isso com você?

( ) Não ( ) Sim Quantas vezes?____ （ ） Isso aconteceu somente em outras relações

19a Você jogou o seu companheiro(a) contra a parede com força? 
( ) Não ( ) Sim Quantas vezes? ( ) Isso aconteceu somente em outras relações

19b Seu companheiro(a) fez isso com você?

( ) Não ( ) Sim Quantas vezes? ( ) Isso aconteceu somente em outras relações

20a Você disse para ele que achava que vocês poderiam resolver o problema?

( ) Não ( ) Sim Quantas vezes? ( ) Isso aconteceu somente em outras relações

20b Seu companheiro(a) disse que achava que você poderiam resolver o problema?

( ) Não ( ) Sim Quantas vezes? ( ) Isso aconteceu somente em outras relações

21a Você deveria ter ido a um médico ou algum serviço de saúde por causa de uma briga com seu companheiro, mas não foi?

( ) Não ( ) Sim Quantas vezes? ( ) Isso aconteceu somente em outras relações

21b Seu companheiro(a) deveria ter ido a um médico ou algum serviço de saúde por causa de uma briga com você, mas não foi?

( ) Não ( ) Sim Quantas vezes? ( ) Isso aconteceu somente em outras relações

22a Você deu uma surra no seu companheiro(a)?

( ) Não ( ) Sim Quantas vezes?____ ( ) Isso aconteceu somente em outras relações

22b Seu companheiro(a) fez isso com você?

( ) Não ( ) Sim Quantas vezes? ( ) Isso aconteceu somente em outras relações

23a Você segurou o seu companheiro(a) com força?

( ) Não ( ) Sim Quantas vezes? ( ) Isso aconteceu somente em outras relações

23b Seu companheiro(a) fez isso com você?

( ) Não ( ) Sim Quantas vezes?____ （ ） Isso aconteceu somente em outras relações

24a Você usou de força como, por exemplo, segurar ou bater nele ou usar uma arma para obrigar o seu companheiro(a) a fazer sexo com você?

( ) Não ( ) Sim Quantas vezes?___ （ ） Isso aconteceu somente em outras relações

24b Seu companheiro(a) fez isso?

( ) Não ( ) Sim Quantas vezes? ( ) Isso aconteceu somente em outras relações

25a Você virou as costas e foi embora no meio de uma discussão?

( ) Não ( ) Sim Quantas vezes? ( ) Isso aconteceu somente em outras relações

25b Seu companheiro(a) fez isso?

( ) Não ( ) Sim Quantas vezes? ( ) Isso aconteceu somente em outras relações

26a Você insistiu em fazer sexo quando o seu companheiro(a) não queria sem usar força física? ( ) Não ( ) Sim Quantas vezes? ( ) Isso aconteceu somente em outras relações

26b Seu companheiro(a) fez isso com você?

( ) Não ( ) Sim Quantas vezes? ( ) Isso aconteceu somente em outras relações

27a Você deu um tabefe ou bofetada no seu companheiro(a)?

( ) Não ( ) Sim Quantas vezes? ( ) Isso aconteceu somente em outras relações

27b Seu companheiro(a) fez isso com você?

( ) Não ( ) Sim Quantas vezes? ( ) Isso aconteceu somente em outras relações

28a Você quebrou um osso por causa de uma briga com o seu companheiro(a)? ( ) Não ( ) Sim Quantas vezes?____ ( ) Isso aconteceu somente em outras relações

28b Seu companheiro(a) quebrou um osso por causa de uma briga com você?

( ) Não ( ) Sim Quantas vezes? ( ) Isso aconteceu somente em outras relações 
29a Você fez ameaças para obrigar o seu companheiro(a) fazer sexo oral ou anal com você?

( ) Não ( ) Sim Quantas vezes? ( ) Isso aconteceu somente em outras relações

29b Seu companheiro(a) fez isso com você?

( ) Não ( ) Sim Quantas vezes?____ ( ) Isso aconteceu somente em outras relações

30a Você sugeriu que procurassem juntos uma solução para resolver as diferenças ou desavenças?

( ) Não ( ) Sim Quantas vezes? ( ) Isso aconteceu somente em outras relações

30b Seu companheiro(a) fez isso?

( ) Não ( ) Sim Quantas vezes?

( ) Isso aconteceu somente em outras relações

31a Você queimou ou derramou líquido quente em seu companheiro(a) de propósito?

( ) Não ( ) Sim Quantas vezes?____ ( ) Isso aconteceu somente em outras relações

31b Seu companheiro(a) fez isso com você?

( ) Não ( ) Sim Quantas vezes?____ （ ） Isso aconteceu somente em outras relações

32a Você insistiu para que seu companheiro(a) fizesse sexo oral ou anal com você sem usar força física?

( ) Não ( ) Sim Quantas vezes? ( ) Isso aconteceu somente em outras relações

32b Seu companheiro(a) fez isso com você?

( ) Não ( ) Sim Quantas vezes?____ ( ) Isso aconteceu somente em outras relações

33a Você acusou o seu companheiro(a) de ser "ruim de cama"?

( ) Não ( ) Sim Quantas vezes?____ ( ) Isso aconteceu somente em outras relações

33b Seu companheiro(a) acusou-o(a) disso?

( ) Não ( ) Sim Quantas vezes?____ ( ) Isso aconteceu somente em outras relações

34a Você fez alguma coisa para ofender o seu companheiro(a)?

( ) Não ( ) Sim Quantas vezes?

( ) Isso aconteceu somente em outras relações

34b Seu companheiro(a) fez isso?

( ) Não ( ) Sim Quantas vezes?

( ) Isso aconteceu somente em outras relações

35a Você ameaçou acertar ou jogar alguma coisa no seu companheiro(a)?

( ) Não ( ) Sim Quantas vezes?

( ) Isso aconteceu somente em outras relações

35b Seu companheiro(a) fez isso?

( ) Não ( ) Sim Quantas vezes?

( ) Isso aconteceu somente em outras relações

36a Você sentiu dores no corpo que duraram até o dia seguinte por causa de uma briga com o seu companheiro(a)?

( ) Não ( ) Sim Quantas vezes?____ （ ） Isso aconteceu somente em outras relações

36b Seu companheiro(a) sentiu dores no corpo que duraram até o dia seguinte por causa de uma briga com você?

( ) Não ( ) Sim Quantas vezes?____ （ ） Isso aconteceu somente em outras relações

37a Você chutou o seu companheiro(a)?

( ) Não ( ) Sim Quantas vezes?____ ( ) Isso aconteceu somente em outras relações

37b Seu companheiro(a) fez isso com você?

( ) Não ( ) Sim Quantas vezes?____ ( ) Isso aconteceu somente em outras relações

38a Você fez ameaças para obrigar o seu companheiro(a) fazer sexo com você?

( ) Não ( ) Sim Quantas vezes?____ ( ) Isso aconteceu somente em outras relações

38 b Seu companheiro(a) fez isso com você?

( ) Não ( ) Sim Quantas vezes?____ （ ） Isso aconteceu somente em outras relações

39a Você concordou com a solução que foi sugerida por ele? 
( ) Não ( ) Sim Quantas vezes?

( ) Isso aconteceu somente em outras relações

39b Seu companheiro(a) concordou em tentar uma solução que você sugeriu?

( ) Não ( ) Sim Quantas vezes?

( ) Isso aconteceu somente em outras relações 


\section{Anexo 2 \\ Termo de Consentimento Livre e Esclarecido}

Você está sendo convidado a participar da pesquisa intitulada: “As práticas sexuais e seus significados para os casais em situação de violência conjugal“. O responsável pela pesquisa é o pesquisador Rafael Gabriel Assis, aluno de mestrado da Universidade de Brasília. O objetivo desta pesquisa é refletir sobre as vivências sexuais dos casais em situação de violência conjugal para conhecer melhor as pessoas que sofrem com a violência conjugal e poder ajudar os casais prevenindo ou tratando o sofrimento relacionado à violência. Assim, gostaria de consultá-lo(a) sobre seu interesse e disponibilidade de cooperar com a pesquisa.

Você receberá todos os esclarecimentos necessários antes, durante e após a finalização da pesquisa, e lhe asseguro que o seu nome não será divulgado, sendo mantido o mais rigoroso sigilo mediante a omissão total de informações que permitam identificálo(a). Os dados provenientes de sua participação na pesquisa, tais como questionários, entrevistas e fitas de gravação ficarão sob a guarda do pesquisador responsável pela pesquisa.

A coleta de dados será realizada por meio de alguns instrumentos:

- Um questionário com dados demográficos e sociais.

- Três entrevistas com o casal para a realização de um mapa familiar com informações sobre a sexualidade da família do casal, como pais, avós e irmãos.

- Uma entrevista individual para compreender suas reflexões sobre casamento, sexualidade e violência.

- Uma entrevista com o casal para o encerramento da pesquisa e avaliação.

É para estes procedimentos que você está sendo convidado a participar. Solicitamos sua autorização para gravação de voz durante as entrevistas. Não haverá, na divulgação da pesquisa, nenhum trecho que identifique você. Os resultados serão divulgados por meios onde se divulgam pesquisas como essa, como congressos, artigos científicos, capítulos de livro, dissertação etc.

Acreditamos que esta pesquisa não acarretará riscos diretos para você. Porém, caso você ou o pesquisador percebam riscos ou dificuldades na pesquisa - como incômodos; sentimentos difíceis de lidar, como ansiedade ou angústia; tensões familiares e sociais - esses podem ser expostos e trabalhados durante os próprios encontros reservados para as entrevistas. Além disso, o pesquisador pode ser procurado a qualquer momento, durante ou após a pesquisa, para atendimento no próprio Pró-Vítima ou encaminhamento associado a qualquer tipo de sofrimento ou prejuízo, causado ou não pela pesquisa. Caso o encaminhamento para outro órgão parceiro seja a melhor opção, o pesquisador se compromete a acompanhar o encaminhamento para que ele se dê da melhor forma possível e o atendimento seja realizado a contento.

Por outro lado, as suas reflexões durante e após as entrevistas podem te ajudar a se sentir melhor com as experiências difíceis envolvendo a sexualidade e a violência que 
você viveu. Isso pode proteger você de alguns sofrimentos e pode te ajudar a lidar melhor com algumas dificuldades no casamento e em outras situações sociais. Sua participação é voluntária e livre de qualquer remuneração ou benefício. Você é livre para recusar-se a participar, retirar seu consentimento ou interromper sua participação a qualquer momento. A recusa em participar não irá acarretar qualquer penalidade ou perda de benefícios, inclusive dos atendimentos no Pró-Vítima.

O senhor pode entrar em contato com os pesquisadores responsáveis a fim de obter qualquer tipo de explicação, pedir indicação de ajuda profissional caso julgue necessário e/ou para obter informações sobre o andamento da pesquisa. Este projeto foi revisado e aprovado pelo Comitê de Ética em Pesquisa do Instituto de Ciências Humanas da Universidade de Brasília - CEP/IH. As informações com relação à assinatura do TCLE ou os direitos do sujeito da pesquisa podem ser obtidos através do e-mail do CEP/IH cep_ih@unb.br.

Este Termo de Consentimento Livre e Esclarecido é redigido em duas vias, uma para a guarda do(s) pesquisador(es) e outra para você guardar.

$\mathrm{Eu}$,

declaro que aceito participar voluntariamente desta pesquisa. Afirmo ainda que autorizo a utilização das informações prestadas por mim para este estudo.

Brasília, de de 2015.

Assinatura do participante

Assinatura do pesquisador responsável

\section{Pesquisadores responsáveis pela pesquisa:}

- Rafael Gabriel Assis (Psicólogo CRP 01/15693 - Mestrando da UnB mat.13/0165859, psicólogo do Pró-Vítima, mat.: 21583-45). Telefone: (61) 81011697/ 2104-1191 Pró-Vítima.

- Gláucia Ribeiro Starling Diniz (Professora de psicologia da UnB - Orientadora) Telefone: (61) 33072625 - Ramal 315.

\section{Contato com o Comitê de Ética em Pesquisa:}

Você também pode entrar em contato com a Coordenação do CEP no endereço: Comitê de Ética em Pesquisa do Instituto de Ciências Humanas da Universidade de Brasília, Campus Universitário Darcy Ribeiro, ICC - Centro mezanino, Departamento de Serviço Social, Sala B1 432, Brasília, DF, CEP 70910-966 ou pelo e-mail cep_ih@unb.br 